\title{
Dynamic Discrepancy Reduced Order Modeling for Fischer- Tropsch Synthesis Over Cobalt-based Catalyst
}

Jose Miguel Bohorquez

West Virginia University, jmbohorquez@mix.wvu.edu

Follow this and additional works at: https://researchrepository.wvu.edu/etd

Part of the Energy Systems Commons

\section{Recommended Citation}

Bohorquez, Jose Miguel, "Dynamic Discrepancy Reduced Order Modeling for Fischer-Tropsch Synthesis Over Cobalt-based Catalyst" (2019). Graduate Theses, Dissertations, and Problem Reports. 7404. https://researchrepository.wvu.edu/etd/7404

This Thesis is protected by copyright and/or related rights. It has been brought to you by the The Research Repository @ WVU with permission from the rights-holder(s). You are free to use this Thesis in any way that is permitted by the copyright and related rights legislation that applies to your use. For other uses you must obtain permission from the rights-holder(s) directly, unless additional rights are indicated by a Creative Commons license in the record and/ or on the work itself. This Thesis has been accepted for inclusion in WVU Graduate Theses, Dissertations, and Problem Reports collection by an authorized administrator of The Research Repository @ WVU. For more information, please contact researchrepository@mail.wvu.edu. 


\title{
Dynamic Discrepancy Reduced Order Modeling for Fischer-Tropsch Synthesis Over Cobalt-based Catalyst
}

\author{
Jose M. Bohorquez \\ Thesis submitted to the \\ Benjamin M. Statler College of Engineering and Mineral Resources \\ at West Virginia University
}

In partial fulfillment of the requirements for the degree of

Master of Science in

Mechanical Engineering

David Mebane, Ph.D., Chair

Fernando V. Lima, Ph.D.

Adam Halasz, Ph.D.

Department of Mechanical and Aerospace Engineering

Morgantown, West Virginia

2019

Keywords: Fischer-Tropsch, Dynamic Discrepancy, Modeling, Design, Cobalt, Sequential Monte Carlo 


\title{
Abstract \\ Dynamic Discrepancy Reduced Order Modeling for Fischer-Tropsch Synthesis Over Cobalt-based Catalyst
}

\author{
Jose M. Bohorquez
}

Advances in carbon capture techniques and demands in alternative fuel sources have increased over the past couple of decades. The Fischer-Tropsch Synthesis (FTS) provides a viable way to produce hydrocarbons from natural gas, coal, $\mathrm{CO}_{2}$, or biomass. However, current comprehensive models for FTS encompass large number of reacting species, readsorption and conversion of primary products, surface intermediates, and coverage-dependent reaction rates. To accurately predict the products obtained through the process a reduced order model has been developed. By reducing the number of parameters of an existing comprehensive model, uncertainty is introduced. The uncertainty can be quantified by using discrepancy functions within the chemical rate equations, there by representing the reduced order model as a set of stochastic differential equations. Representing the uncertainty as model discrepancy functions, a Bayesian approach is used to calibrate the reduced order model to data obtained from literature. Through a Bayesian Smoothing Splines (BSS-ANOVA) framework, the stochastic differential equations are decoupled into deterministic differential equations and stochastic coefficients. The parameters are solved for using a Sequential Monte Carlo approach with importance sampling. Through the use of these stochastic coefficients, fidelity is restored to the reduced order model. Thus, the model can be fully described by fewer parameters than initially needed, as well as a reduction in the computational complexity. 


\section{Dedicated to my mom Ana, my sisters Tatiana and Briana, my brother Miguel, and my late cousin Sachika}




\section{Acknowledgements}

The knowledge and experience I gained while in the MAE program is not only attributed to all the wonderful instructors at WVU but, also my graduate committee consisting of Dr. David Mebane, Dr. Fernando V. Lima, and Dr. Adam Halasz. First, I would like to thank Dr. David Mebane for all the help and support throughout my graduate studies. His support as my research advisor allowed me to grow as a researcher and as a student. I'd also like to extend my gratitude towards Dr. Fernando V. Lima for serving as my co-advisor. His patience and motivation guided me through the completion of this thesis. I'd like to thank Dr. Adam Halasz as well, for all the technical help provided throughout this project. Finally, I'd like to thank Elizabeth Ridgeway for her help in the completion of this thesis.

I extend all my gratitude to all my friends for all the support and encouragement through my graduate studies, I'd specifically like to thank: Tufik B., William R., Roberto R., Evan V., Joseph G., Michael L., Josh R., Brian T., Aaron C., Phillip D., Jonathan S., Adam J., Joseph D., Aaron P., Felipe F., Mehdi A., Weston P., Sarmad A., Denali H., John C., Sarah C., Michael C., Wendy A., Matthew M., Edward N., Steven M., Christine F., and Raul R. I'd also like to thank all of the CODES group, and the Mebane group for their support.

Finally, and most importantly, I'd like to thank my mom, Ana, for all the sacrifices she has made to allow me to pursue a higher education. Her support and encouragement have always allowed me to achieve the unachievable. 


\section{Table of Contents}

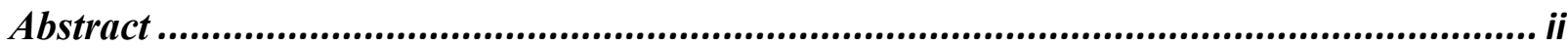

Acknowledgements ................................................................................ iv

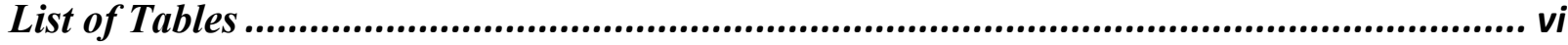

List of Figures ...................................................................................... vii

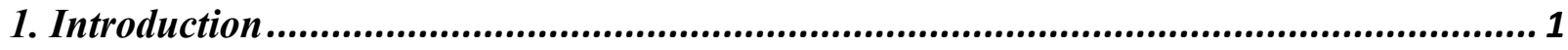

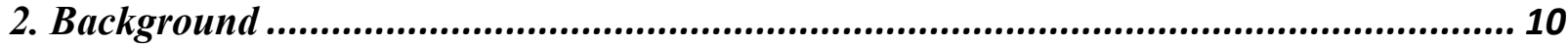

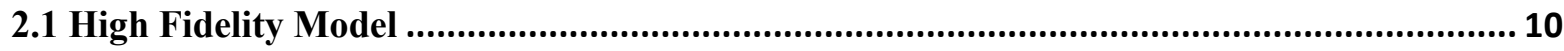

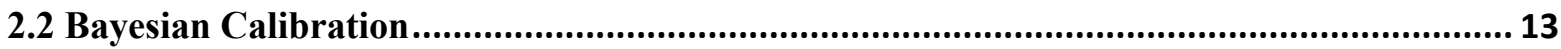

2.3 Bayesian Smoothing Spline Analysis of Variance (BSS-ANOVA) .................................... 15

2.4 Reduced Order Modeling Calibration with Dynamic Discrepancy ................................... 17

2.5 Approximate Bayesian Computation using Sequential Monte Carlo Sampler.................... 17

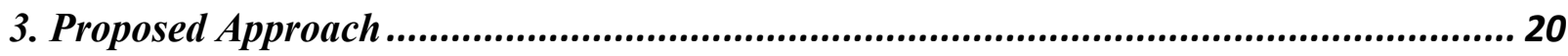

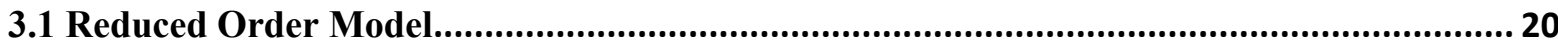

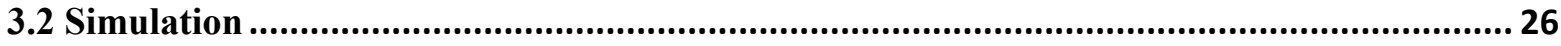

4. Results ................................................................................................ 27

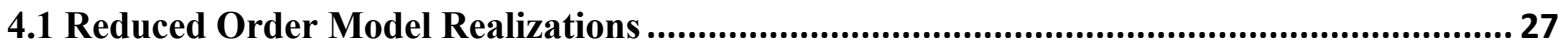

4.2 Convergence and Statistics of Simulation ..................................................................... 32

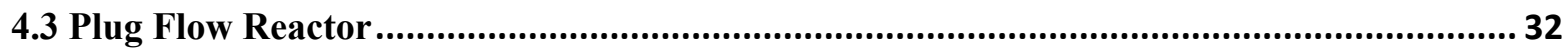

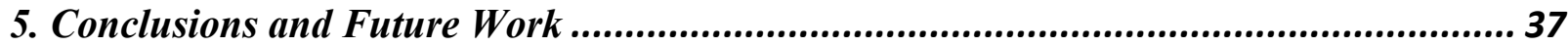

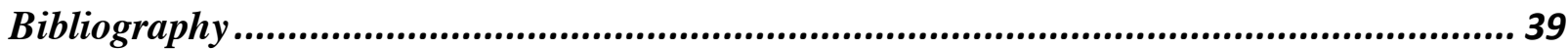

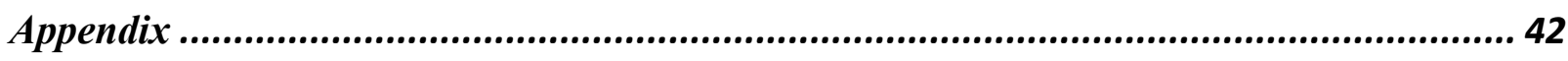




\section{List of Tables}

Table 1: Product classifications, properties and applications ................................................ 5

Table 2: Statistics of the Posterior distribution for the baseline case .................................... 47

Table 3:Statistics of the Posterior distribution for the dynamic discrepancy case.................... 53 


\section{List of Figures}

Figure 1: Ratio of the energy source of the global annual energy consumption, 2015............. 1 Figure 2: Fischer-Tropsch synthesis provides an alternative pathway for the synthesis of hydrocarbons from natural gas, coal, $\mathrm{CO} 2$ or biomass ......................................................... 2

Figure 3: Closed Loop Energy Consumption Process ..................................................... 3

Figure 4: Transition metals used in Fischer-Tropsch and their production ............................ 4

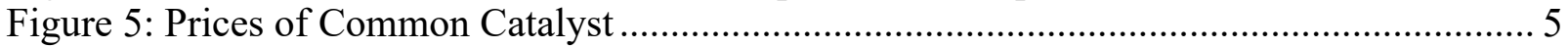

Figure 6: Flow Diagram for the Reaction Mechanism ...................................................... 10

Figure 7: Azadi et Al. Reaction network expanded for up to 28 Carbon Numbers.................. 12

Figure 8: Bayesian Calibration Model .................................................................................... 14

Figure 9: First nine eigenfunctions from the Karhunen-Loeve expansion for a main effect function from the BSS-ANOVA covariance. (adapted from (Storlie, Lane, Ryan, Gattiker, \& Higdon, 2015)) ........................................................................................................... 16

Figure 10: Sequential Monte Carlo Sampler with Importance Sampling and Resampling ....... 19

Figure 11: Reduced Order Model Reaction Network .................................................... 20

Figure 12: Anderson-Schulz-Flory (ASF) distribution in terms of mole percent, for $\alpha=0.9 \ldots 21$ Figure 13: ROM Realizations vs experimental data for reactants with and without discrepancy

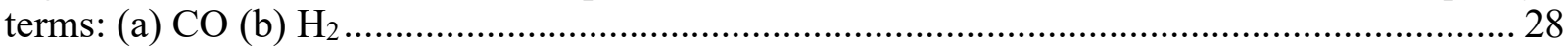

Figure 14: ROM Realizations vs experimental data for products with and without discrepancy

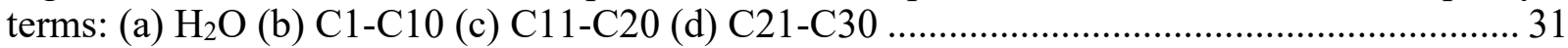

Figure 15: PFR ROM Realizations for reactants: (a) $\mathrm{CO}$ (b) $\mathrm{H}_{2}$........................................ 33

Figure 16: PFR ROM Realizations for products: (a) $\mathrm{H}_{2} \mathrm{O}$ (b) $\mathrm{C} 1-\mathrm{C} 10$ (c) $\mathrm{C} 11-\mathrm{C} 20$ (d) $\mathrm{C} 21-\mathrm{C} 30$ 


\section{Introduction}

The Fischer-Tropsch Synthesis dates back to the early twentieth century, when the German scientist Franz Fischer and Hans Tropsch showed the technology in their U.S. patent titled, "Process for the Production of Paraffin-Hydrocarbons with More Than One Carbon Atom" (United States of America Patent No. 1746464, 1930). It was during WWII that this process was further investigated by the Technical Oil Mission in Germany (Miller, 1945). Towards the end of the war, there were nine plants in operation using cobalt based catalyst in Germany. After the end of the war, these plants were shut down. It wasn't until the oil shortage of the mid 1970's that the Fischer-Tropsch synthesis was once again explored. In recent years, the Fischer-Tropsch synthesis has gained popularity as the world's oil reserves are depleted. According to the World Energy Council, about 10 percent of the world's total energy production is based on renewable energy sources such as solar, wind, geothermal and hydro-electrical energy (Hans-Wilhelm Schiffer, 2016). Meanwhile natural gas, oil and coal are the predominant energy sources, as seen in Figure 1.

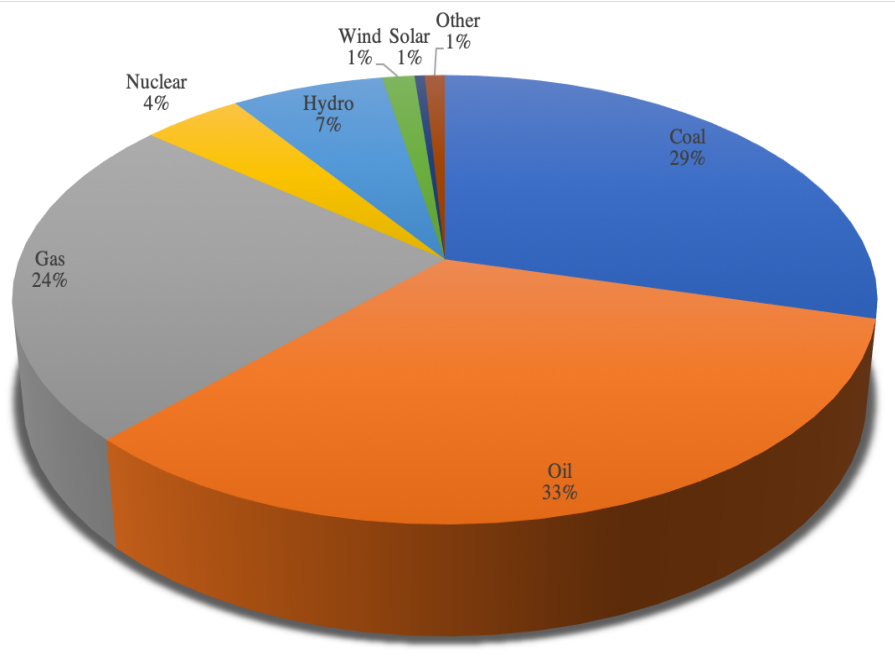

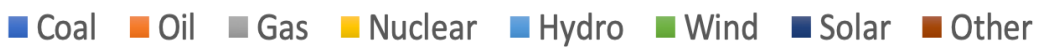

Figure 1: Ratio of the energy source of the global annual energy consumption, 2015 
A rough estimate based on the 2016 reserves and consumption by the U.S. Energy Information Administration tells us that we have natural gas and oil for about half a century left (U.S. Energy Information Administration, 2017). Based on this estimate, relying solely on the refinement of crude oil to meet energy demands will eventually lead to an oil shortage. Thus, exploring an alternative for fuel generation is of interest. The Fischer-Tropsch synthesis provides a viable alternative. Figure 2 (Schouten, Hensen, \& van Santen, 2015) shows how the FischerTropsch synthesis can aid in the production of fuels.

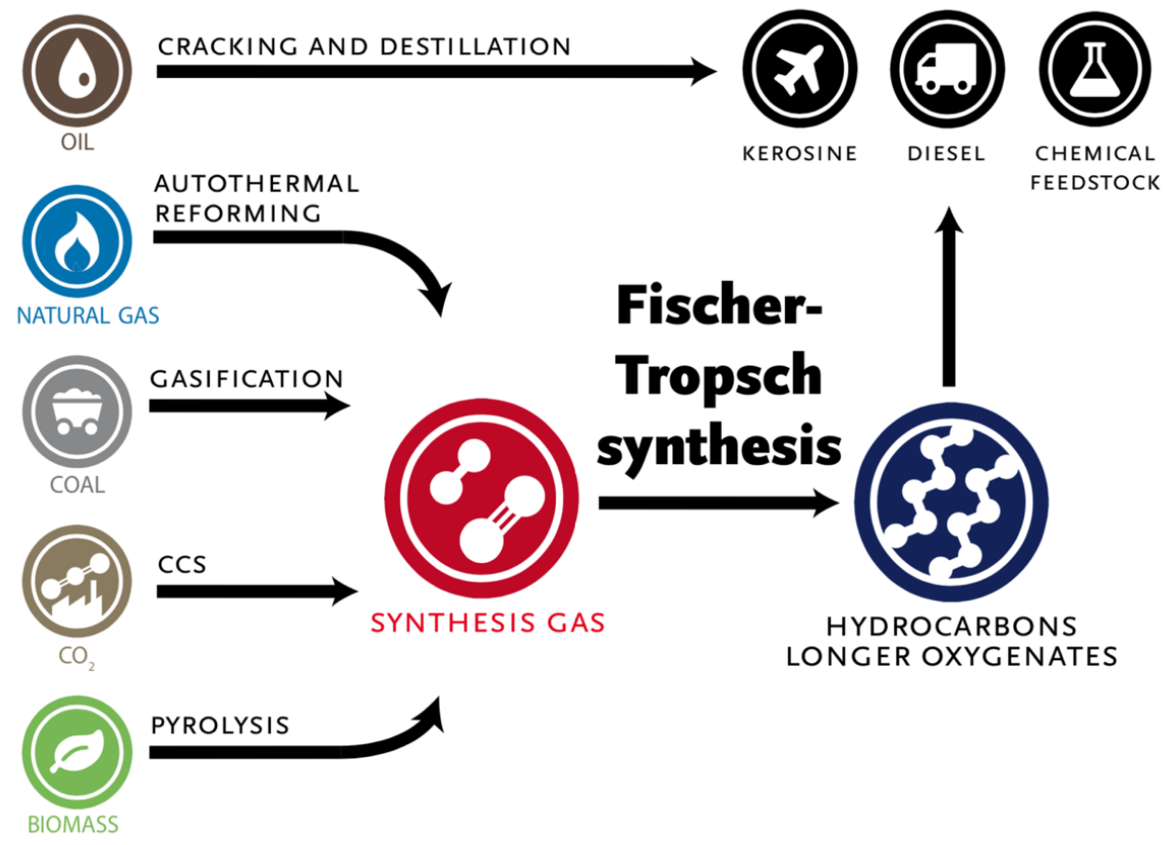

Figure 2: Fischer-Tropsch synthesis provides an alternative pathway for the synthesis of hydrocarbons from natural gas, coal, CO2 or biomass

As shown in Figure 2, Syngas can be obtained through the decomposition of biomass by the pyrolysis effect (Zafar, 2019), coal gasification (Wagner, Coertzen, \& Matjie, 2008), carbon capture and storage of carbon dioxide $\left(\mathrm{CO}_{2}\right)$ emissions (Center for Climate and Energy Solutions, 2019), and auto-thermal reforming of natural gas (Rice \& Mann, 2007). These sources 
of syngas can be used to produce a renewable energy-like system as shown in Figure 3

(Brandtner, 2018).

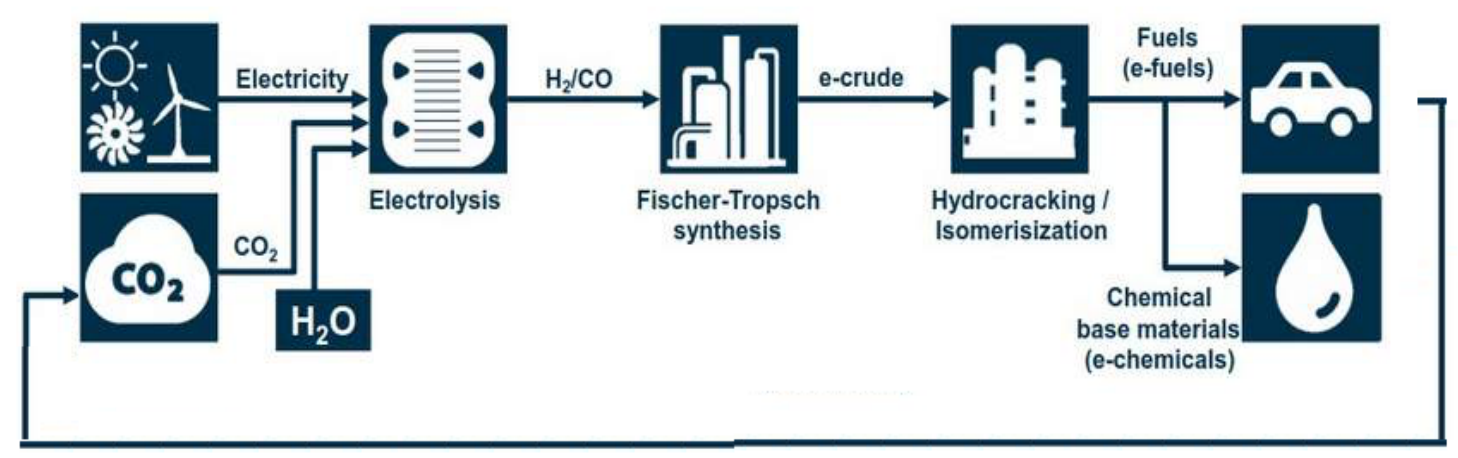

Figure 3: Closed Loop Energy Consumption Process

The benefit of having such sources to create fuel and alleviate our dependence on other sources justifies further exploration of the Fischer-Tropsch synthesis.

The Fischer-Tropsch synthesis is a heterogeneous catalytic process that converts syngas $\left(\mathrm{H}_{2} / \mathrm{CO}\right)$ derived from carbon sources such as coal, natural gas or biomass, into liquid fuels and chemicals with a high cetane number and without any aromatic compounds such as Sulphur and Nitrogen (Zhou L. , 2016).

The products created through the Fischer-Tropsch synthesis, depend on the choice of the catalyst. Figure 4 shows the possible metals for use in the Fischer-Tropsch synthesis, while Table 1 shows the product classifications, properties and their applications. 


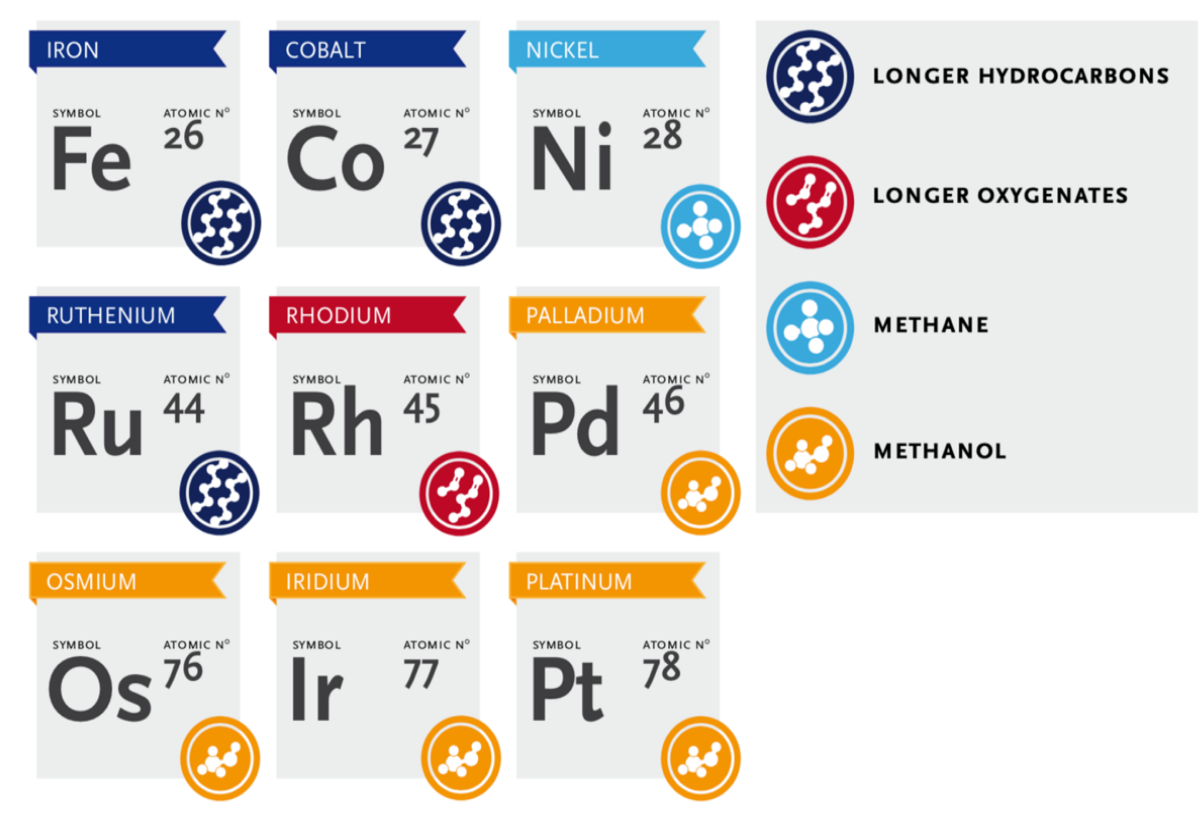

Figure 4: Transition metals used in Fischer-Tropsch and their production

\begin{tabular}{|c|c|c|c|}
\hline $\begin{array}{l}\text { Petroleum fraction / } \\
\text { Physical state }\end{array}$ & Product & $\begin{array}{c}\text { Number of Carbon } \\
\text { Atoms }\end{array}$ & Uses \\
\hline \multirow[t]{4}{*}{ Petroleum gas / Gas } & Methane & 1 & $\begin{array}{l}\text { Heating, cooking, } \\
\text { electricity }\end{array}$ \\
\hline & Ethane & 2 & Plastics, petrochemicals \\
\hline & Propane & 3 & LPG, transport, domestic \\
\hline & Butane & 4 & use \\
\hline \multirow[t]{2}{*}{ Light ends / Liquids } & Naptha & $5-11$ & $\begin{array}{c}\text { Petrochemicals, solvents, } \\
\text { gasoline }\end{array}$ \\
\hline & Gasoline & $7-10$ & Transport \\
\hline Middle distillates / & Kerosene & $11-18$ & Jet fuel, heating cooking \\
\hline Liquids & Gas oil & $11-18$ & Diesel, heating \\
\hline
\end{tabular}




\begin{tabular}{|c|c|c|c|}
\hline $\begin{array}{c}\text { Heavy ends / } \\
\text { Liquids }\end{array}$ & Lubricating oil & $18-25$ & $\begin{array}{c}\text { Motor oil, transmission } \\
\text { oil, lubricants }\end{array}$ \\
\hline Liquids & Residual fuel oil & $20-27$ & Shipping fuel, electricity \\
\hline \multirow[t]{3}{*}{ Heavy ends / Solids } & Greases \& Wax & $25-30$ & Lubricants \\
\hline & Bitumen & $35+$ & Roads, roofing \\
\hline & Coke & $50+$ & Steel production \\
\hline
\end{tabular}

Table 1: Product classifications, properties and applications

Figure 4 shows that the Fischer-Tropsch synthesis product formation is catalyst dependent. The most common catalysts used in industry are Iron (Fe), Nickel (Ni), Cobalt (Co), Ruthenium ( $\mathrm{Ru})$, and Rhodium (Rh). Nickel is not preferred due to the high methane selectivity. Figure 5 (Schouten, Hensen, \& van Santen, 2015) shows that Iron is the cheapest of the options, however the use of iron leads to carbon deposition which reduces the efficiency of the overall synthesis (Dry, 1990). Ruthenium availability is scarce and as such it becomes inefficient for production, while Rhodium is not cost effective. Hence the reason Cobalt is one of the most researched catalyst in use.

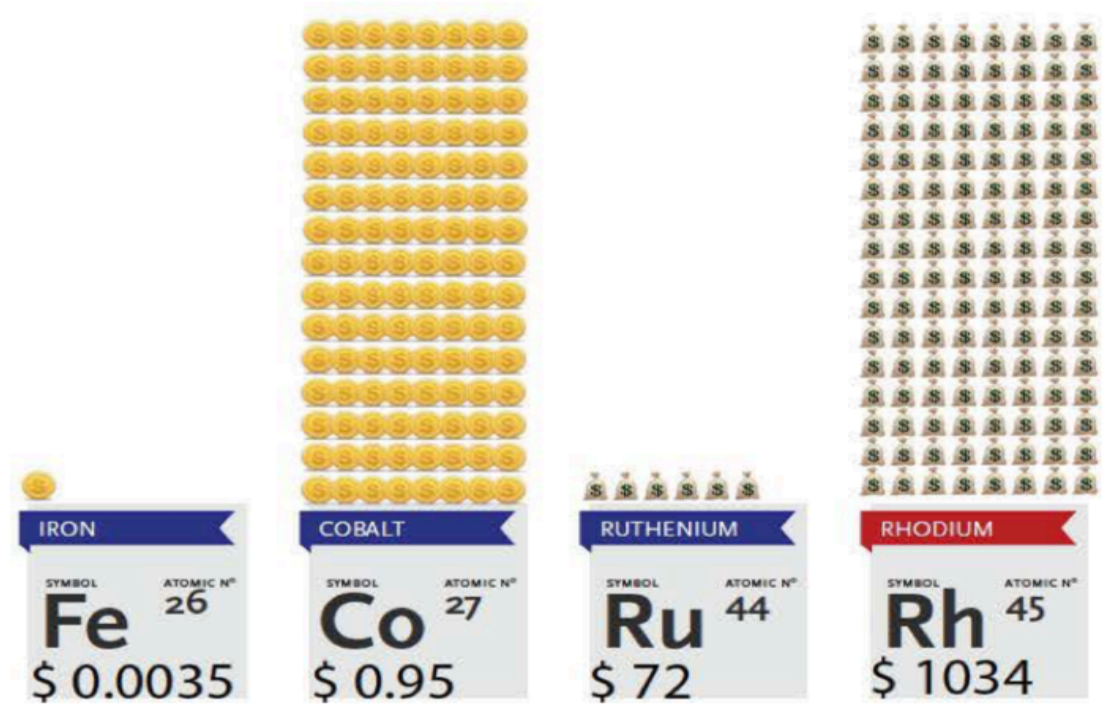

Figure 5: Prices of Common Catalyst 
Current and ongoing research on the Fischer-Tropsch synthesis can be broken down into three categories: Experimental, Reactor Design, and Modeling of synthesis. These categories, however, are not mutually exclusive.

Experimental research currently focuses on addition of promoter and supported additives over catalyst to maximize productivity and selectivity of longer-chain products (Bukur, Lang, Mukesh, \& Zimmerman, 1990).

The modeling of the Fischer-Tropsch synthesis is reactor dependent as Guettel and Turek demonstrated in their paper "Comparison of different reactor types for low temperature FischerTropsch synthesis: A simulation study" (Guettel \& Turek, 2009). The reactors in the study were fixed bed, slurry bubble column, monolith loop, and micro-structured each modeled with a pseudo-homogeneous one-dimensional approach.

The most basic reactor model is the pseudo-homogenous one-dimensional model, used to model a continuous-flow stirred tank reactor (CSTR) (Pratt, 2012). The separate effects of catalyst and fluid on mass transfer are lumped together, and temperature and concentration are the same for both the fluid and catalyst (pseudo-homogeneous). Concentration change is simply a function of the extent of reaction within the reactor. Higher fidelity can be achieved by extending this approach to a two-dimensional approach, taking radial mixing into consideration. Heterogeneous one-dimensional and two-dimensional models have also been developed (Wang, Xu, Li, Zhao, \& Zhang, 2003). These models are typically used to model fixed-bed reactors (FBR) (Froment, Bischoff, \& De Wild, 1999).

Kinetic models of the Fischer-Tropsch Synthesis are hard to find, since the kinetics are largely unknown, due to the large number of reacting species, reabsorption and conversion of primary products, difficulties in measuring surface intermediates, and coverage-dependent reaction rates (Azadi, Brownbridge, Kemp, Mosbach, \& Dennis, Microkinetic Modeling of the 
Fischer-Tropsch Synthesis over Cobalt Catalysts, 2015). As such, the kinetic models are still debated in the literature. Nonetheless, the existing kinetic models can be classified into three categories: 1. Overall reactant consumption models, 2. Hydrocarbon product distribution models ,and 3. Comprehensive kinetic models.

Reactant consumption models were among the first to be developed first by Anderson in 1956 (Anderson, 1956), then Sarup and Wojciechowski in 1989 (Sarup \& Wojciechowski, 1989), and then Zimmerman and Bukur in 1990 (Zimmerman \& Bukur, 1990). These types of models are useful for initial design and reactor sizing. For more detailed reactor designs, these types of models are coupled with Hydrocarbon product distribution model to accurately model reactant and product formation rates (Rafiee \& Hillestad, 2011).

The first hydrocarbon product distribution model was introduced by Anderson (Friedel \& Anderson, 1950). Anderson's model evolved from a proposed polymerization model by Schulz (Schultz, 1935) and Flory (Flory, 1936). This model became known as the Anderson-SchulzFlory (ASF) model. It should be noted that the FT product distribution typically deviates from the ASF prediction in terms of methane $(\mathrm{C} 1)$, yielding higher-than-expected $\mathrm{C} 1$ products, and ethane + ethene $(\mathrm{C} 2)$, yielding lower-than-expected products. To make up for the non-ASF behavior, different selectivity models have been created such as the 2-alpha selectivity model (Chaumette, Verdon, \& Boucot, 1995), methane kinetic, alpha for all others (Jess \& Kern, 2009), desorption controlled (Botes, 2007), etc. Despite these attempts, since a single parameter describes the distribution of the entire product range and is modeled by empirical power-law kinetics, some parameters end up not making physical sense (Van Der Laan \& Beenackers, 1999). These types of models are primarily aimed at catalyst improvement (Fontenelle Jr \& Fernandes, 2011). Due to the model being described by a single parameter, this type of model is the easiest to implement, computationally (Zhou, et al., 2010). 
Recently, comprehensive kinetic models based on Langmuir-Hinshelwood-HougenWatson (LHHW) rate expressions, as well as models based on single-event methodology have been surfacing in literature. The most comprehensive model comes from Zhang et al., which includes Water-Gas Shift, Olefin (ethene) reabsorption, dual polymerization process (carbon monoxide and ethane addition (Zhang, et al., 2009). This model accurately predicts hydrocarbon product distribution up to carbon number 45 (C45). The high complexity of this model makes it computationally inefficient to implement, as even a simulation of product distribution up to carbon number 5 includes about 100 equations. Tian et al. presented a similar comprehensive microkinetic model based solely on activation energies and a proposed reaction mechanism (Tian, et al., 2010). Similarly, this model has 31 equations to predict the distribution of products up to carbon number 2. No interpretation of results was presented to discuss accuracy of proposed model.

Currently, there is a lack of models that predict product distribution as accurately as the comprehensive kinetic models yet remain computationally inexpensive as the hydrocarbon product distribution models. The need for fast computational models arises from model-based process control and online optimization to increase yield and efficiency during the FischerTropsch Synthesis.

This thesis aims to fill in these gaps. By adapting the comprehensive model developed by Azadi, we reduce the order of this model by assuming that the product formations can be described solely by the inputs and outputs. That is, we assume that the reactions over the catalyst sites produce products that are of relatively low concentrations, and as such they can be neglected as they are accounted for through mass conservation in gas phase. This reduction of order allows us to simplify our reaction network and therefore the computational complexity, while retaining the comprehensive kinetics that the model is based on. 
The reduced order model introduces uncertainty, and therefore correction terms are added in the form of discrepancy terms. Model form discrepancy is represented using a Gaussian Process with a Bayesian Smoothing Spline (BSS)-ANOVA covariance (Mebane, Storlie, Mahapatra, \& Sham Bhat, 2014). These discrepancy terms are included within the model equations, resulting in stochastic differential equations (SDEs). Representing the system as a set of SDEs allows the dynamic system to change paths. As such, we call these correction terms dynamic discrepancy terms.

We use a Bayesian approach to calibrate the model to data obtained in literature from experiments performed and reported by Visconti et al (Visconti, Tronconi, Lietti, Zennaro, \& Forzatti, 2006). The resulting approach leads to a joint- sample distribution of model parameters and basis function coefficients. A Sequential Monte Carlo (SMC) routine is used to search for variable sets that are able to match the data. The SMC routine is used due to the flexibility, scalability and ease of implementation (Frellsen \& Bui, 2014). Furthermore, the SMC routine employs the usage of resampling and importance sampling, such that the particles used to search for variable sets have a good balance between exploration and exploitation. This routine restores the fidelity to the reduced order model and allows for the parameter uncertainties represented in the posterior distribution to be propagated upward into a larger-scale system.

Through the introduction of more discrepancy terms we can further reduce the error, however model complexity and computational time would increase. The model presented in this thesis aims at achieving a balance between model complexity and computational time, while retaining the thoroughness of the comprehensive model. This is achieved empirically, through the addition of discrepancy terms added to the model and their effect on the error vs the overall computational time. 


\section{Background}

\subsection{High Fidelity Model}

The proposed reaction network by Azadi et al. (Azadi, Brownbridge, Kemp, Mosbach, \& Dennis, Microkinetic Modeling of the Fischer-Tropsch Synthesis over Cobalt Catalysts, 2015) is shown in Figure 6. This reaction network includes intermediates steps over the catalyst, such as monomer formation, $\mathrm{H}$ abstraction, and hydrogenation, as well as the product formations and water gas shift.

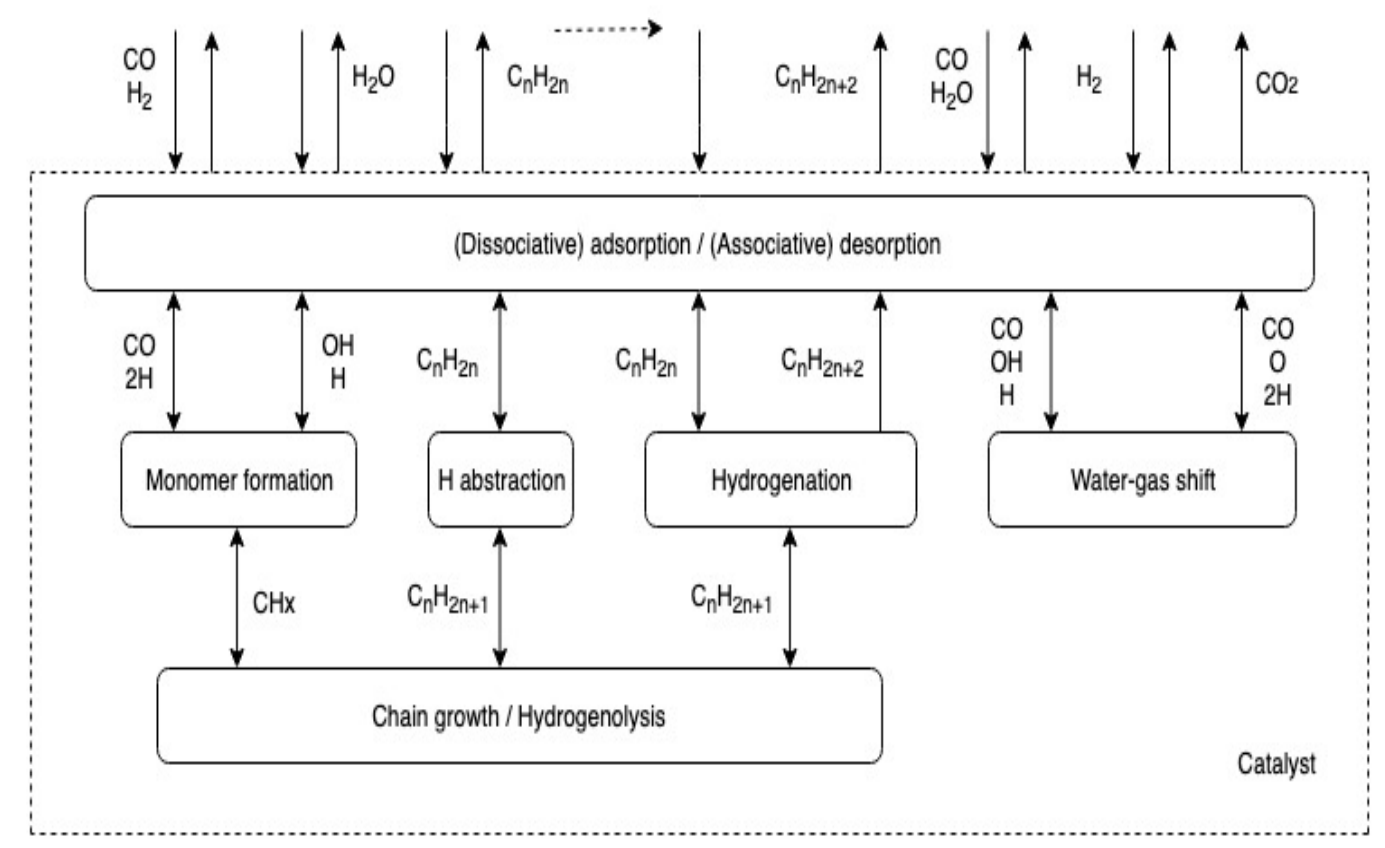

Figure 6: Flow Diagram for the Reaction Mechanism

The result of the complex reactions of Fischer-Tropsch synthesis is a wide distribution of products, namely straight chain hydrocarbons. The process includes a lot of desirable chemical reactions which produce paraffins, olefins and alcohols as well as some unfavorable and unwanted reactions resulting in aldehydes, ketones, acids, esters, carbon, etc. We can describe the reaction that occurs during the Fischer-Tropsch synthesis as: 
Main reactions:

Paraffins formation: $\quad(2 \mathrm{n}+1) \mathrm{H}_{2}+n \mathrm{CO} \rightarrow \mathrm{C}_{n} \mathrm{H}_{2 n+2}+\mathrm{nH}_{2} \mathrm{O}$

Olefins formation:

$2 \mathrm{nH}_{2}+\mathrm{nCO} \rightarrow \mathrm{C}_{n} \mathrm{H}_{2 n}+\mathrm{nH}_{2} \mathrm{O}$

Water-gas shift:

$\mathrm{CO}+\mathrm{H}_{2} \mathrm{O} \leftrightarrow \mathrm{CO}_{2}+\mathrm{H}_{2}$

Side reactions:

Alcohol formation:

$$
2 \mathrm{nH}_{2}+\mathrm{nCO} \rightarrow \mathrm{C}_{n} \mathrm{H}_{2 n+1} \mathrm{OH}+(\mathrm{n}-1) \mathrm{H}_{2} \mathrm{O}
$$

Aldehydes formation: $\quad(2 \mathrm{n}+1) \mathrm{H}_{2}+(\mathrm{n}+1) \mathrm{CO} \rightarrow \mathrm{C}_{n} \mathrm{H}_{2 n+1} \mathrm{COH}+\mathrm{nH}_{2} \mathrm{O}$

Boudouard reaction: $\quad 2 \mathrm{CO} \leftrightarrow \mathrm{C}+\mathrm{CO}_{2}$

Carbon deposition: $\quad \mathrm{CO}+\mathrm{H}_{2} \leftrightarrow \mathrm{C}+\mathrm{H}_{2} \mathrm{O}$

Furthermore, the proposed model assumes the following:

1. The reactor is isothermal and homogeneous

2. The rate of the reaction is controlled by intrinsic surface kinetics and not mass transfer

3. The catalyst contains only one type of active site, and all reactions occur competitively on the surface of metal nanoparticles

4. The pre-exponential factors and activation energies are coverage independent

The products formed through the Fischer-Tropsch process are highly dictated by operating conditions, such as reactor temperature and pressure, gas hourly space velocity, $\mathrm{H}_{2} / \mathrm{CO}$ feed molar ratio, type of reactor, and catalyst and its support, etc.

More importantly, the number of desired carbon numbers to model dictate the complexity of this high-fidelity model. As seen in Figure 7, Azadi et al. expanded the desired number of 
carbon numbers up to 28, which resulted in 95 reversible reactions, and 33 irreversible reactions, roughly translating to 223 equations.

\begin{tabular}{|c|c|c|c|c|c|}
\hline $\begin{array}{l}\text { Elementary } \\
\text { step }\end{array}$ & Reaction & $A_{\mathrm{f}}$ & $E_{\mathrm{f}}$ & $A_{\mathrm{r}}$ & $E_{\mathrm{r}}$ \\
\hline \multicolumn{6}{|c|}{ Adsorption-desorption } \\
\hline 1 & $\mathrm{H}_{2}+2^{*} \leftrightarrow 2 \mathrm{H}^{*}$ & $1.0 \times 10^{3}$ & - & $6.8 \times 10^{12}$ & 48.1 \\
\hline 2 & $\mathrm{CO}+{ }^{*} \leftrightarrow \mathrm{CO}^{*}$ & $1.0 \times 10^{3}$ & - & $1.9 \times 10^{16}$ & 86.7 \\
\hline 3 & $\mathrm{C}_{2} \mathrm{H}_{4}+2^{*} \leftrightarrow \mathrm{C}_{2} \mathrm{H}_{4}^{* *}$ & $1.3 \times 10^{7}$ & 32.2 & $1.0 \times 10^{17}$ & 155.0 \\
\hline 4 & $\mathrm{C}_{3} \mathrm{H}_{6}+2^{*} \leftrightarrow \mathrm{C}_{3} \mathrm{H}_{6}^{* *}$ & $5.4 \times 10^{10}$ & 71.9 & $4.1 \times 10^{13}$ & 91.9 \\
\hline $5-31$ & $\mathrm{C}_{n} \mathrm{H}_{2 n}+2^{*} \leftrightarrow \mathrm{C}_{n} \mathrm{H}_{2 n}^{* *}$ & $3.7 \times 10^{17[b]}$ & 133.6 & $1.9 \times 10^{13[c]}$ & 90.4 \\
\hline 32 & $\mathrm{H}_{2} \mathrm{O}+2^{*} \leftrightarrow \mathrm{OH}^{*}+\mathrm{H}^{*}$ & $6.0 \times 10^{8}$ & 58.9 & $1.8 \times 10^{13}$ & 123.0 \\
\hline \multicolumn{6}{|c|}{ Monomer formation } \\
\hline 33 & $\mathrm{CO}^{*}+\mathrm{H}^{*} \leftrightarrow \mathrm{HCO}^{*}+{ }^{*}$ & $8.4 \times 10^{12}$ & 128.1 & $1.9 \times 10^{12}$ & 54.1 \\
\hline 34 & $\mathrm{HCO}^{*}+\mathrm{H}^{*} \leftrightarrow \mathrm{HCOH}^{* *}$ & $6.1 \times 10^{15}$ & 84.3 & $8.1 \times 10^{8}$ & 121.8 \\
\hline 35 & $\mathrm{HCOH}^{* *}+2^{*} \leftrightarrow \mathrm{CH}^{* * *}+\mathrm{OH}^{*}$ & $2.2 \times 10^{13}$ & 44.0 & $5.5 \times 10^{10}$ & 75.1 \\
\hline 36 & $\mathrm{CH}^{* * *}+\mathrm{H}^{*} \leftrightarrow \mathrm{CH}_{2}^{* *}+2^{*}$ & $1.0 \times 10^{13}$ & 34.7 & $4.2 \times 10^{10}$ & 18.8 \\
\hline \multicolumn{6}{|c|}{ Chain growth } \\
\hline 37 & $\mathrm{CH}_{2}^{* *}+\mathrm{CH}_{2}^{* *} \leftrightarrow \mathrm{C}_{2} \mathrm{H}_{4}^{* *}+2^{*}$ & $1.2 \times 10^{14}$ & 4.5 & $5.6 \times 10^{5}$ & 28.5 \\
\hline 38 & $\mathrm{C}_{2} \mathrm{H}_{5}^{*}+\mathrm{CH}_{2}^{* *} \leftrightarrow \mathrm{C}_{3} \mathrm{H}_{7}^{*}+2^{*}$ & $3.0 \times 10^{12}$ & 39.5 & $1.5 \times 10^{13}$ & 107.0 \\
\hline 39 & $\mathrm{C}_{3} \mathrm{H}_{7}^{*}+\mathrm{CH}_{2}^{* *} \leftrightarrow \mathrm{C}_{4} \mathrm{H}_{9}^{*}+2^{*}$ & $1.6 \times 10^{14}$ & 57.3 & $4.9 \times 10^{6}$ & 57.8 \\
\hline $40-65$ & $\mathrm{C}_{n} \mathrm{H}_{2 n+1}{ }^{*}+\mathrm{CH}_{2}{ }^{* *} \leftrightarrow \mathrm{C}_{n+1} \mathrm{H}_{2 n+3}{ }^{*}+2^{*}$ & $5.0 \times 10^{13[\mathrm{~d}]}$ & 53.1 & $6.8 \times 10^{11}$ & 163.0 \\
\hline \multicolumn{6}{|c|}{ Hydrogenation-H abstraction } \\
\hline 66 & $\mathrm{CH}_{2}^{* *}+\mathrm{H}^{*} \leftrightarrow \mathrm{CH}_{3}^{*}+2^{*}$ & $1.5 \times 10^{14}$ & 69.6 & $4.7 \times 10^{9}$ & 52.9 \\
\hline 67 & $\mathrm{C}_{2} \mathrm{H}_{4}^{* *}+\mathrm{H}^{*} \leftrightarrow \mathrm{C}_{2} \mathrm{H}_{5}^{*}+2^{*}$ & $6.8 \times 10^{16}$ & 126.6 & $2.8 \times 10^{7}$ & 34.1 \\
\hline 68 & $\mathrm{C}_{3} \mathrm{H}_{6}^{* *}+\mathrm{H}^{*} \leftrightarrow \mathrm{C}_{3} \mathrm{H}_{7}^{*}+2^{*}$ & $1.5 \times 10^{13}$ & 59.2 & $4.1 \times 10^{10}$ & 53.3 \\
\hline 69-95 & $\mathrm{C}_{n} \mathrm{H}_{2 n^{* *}}+\mathrm{H}^{*} \leftrightarrow \mathrm{CnH}_{2 n+1}{ }^{*}+2^{*}$ & $1.1 \times 10^{14}$ & 66.8 & $1.9 \times 10^{12}$ & 68.2 \\
\hline 96 & $\mathrm{CH}_{3}{ }^{*}+\mathrm{H}^{*} \rightarrow \mathrm{CH}_{4}+2^{*}$ & $3.4 \times 10^{17}$ & 141.0 & & \\
\hline 97 & $\mathrm{C}_{2} \mathrm{H}_{5}^{*}+\mathrm{H}^{*} \rightarrow \mathrm{C}_{2} \mathrm{H}_{6}+2^{*}$ & $1.5 \times 10^{14}$ & 131.0 & & \\
\hline $98-125$ & $\mathrm{C}_{n} \mathrm{H}_{2 n+1}{ }^{*}+\mathrm{H}^{*} \rightarrow \mathrm{C}_{n} \mathrm{H}_{2 n+2}+2^{*}$ & $1.1 \times 10^{15}$ & 138.8 & & \\
\hline \multicolumn{6}{|c|}{ Water-gas shift } \\
\hline 126 & $\mathrm{OH}^{*}+\mathrm{OH}^{*} \rightarrow \mathrm{H}_{2} \mathrm{O}+\mathrm{O}^{* *}$ & $9.3 \times 10^{11}$ & 135.3 & & \\
\hline 127 & $\mathrm{CO}^{*}+\mathrm{O}^{* *} \rightarrow \mathrm{CO}_{2}+3^{*}$ & $8.7 \times 10^{8}$ & 18.2 & & \\
\hline 128 & $\mathrm{H}^{*}+\mathrm{O}^{* *} \rightarrow \mathrm{OH}^{*}+2^{*}$ & $2.2 \times 10^{16}$ & 86.2 & & \\
\hline
\end{tabular}

Figure 7: Azadi et Al. Reaction network expanded for up to 28 Carbon Numbers

As pointed out within the text, Azadi reduced the complexity of the proposed model through some simplifying assumptions in order to arrive at these reactions. For example, with regard to the monomer formation group, only elementary reactions representing $\mathrm{H}_{2}$-assisted $\mathrm{CO}$ deoxygenation were considered and the carbide mechanism was excluded from the analysis. The 
yield of oxygenated hydrocarbons was neglected as well. Thus, even with some simplifying assumptions the complexity of this model remains high.

\subsection{Bayesian Calibration}

Computer simulations are often developed to be generic and compatible with user defined input parameters. Often times, some of these parameters may not be known and may be extrapolated from physical observations. Through this manner, one may fit the built model to the gathered data from the observations in order to study these unknown parameters. This model fitting process is known as calibration. Traditional calibration techniques search for sets of values such that the output of the model fit as close as possible to the observed data. However, these techniques introduce uncertainty to future model predictions as the model parameters introduced through calibration are estimates.

Through a Bayesian approach to calibration, the predictions allow for all sources of uncertainty to be quantified and attempts to reduce the discrepancy between the observed data and model output (Kennedy \& O'Hagan, 2001). The Bayesian calibration framework presented by Kennedy and O'Hagan is given as:

$$
Y_{n}=\eta\left(x_{n}, \theta\right)+\delta\left(x_{n}\right)+\epsilon_{n}
$$

Where $Y_{n}$ is the output, $x_{n}$ is the model input, $\eta(x, \theta)$ is the computer model, $\theta$ is a vector of model parameters, $\delta\left(x_{n}\right)$ is model form discrepancy function, and $\epsilon_{n}$ is the observational error. The objective of calibration is to estimate $\theta$ and the discrepancy function $\delta$. To achieve these estimates, a prior distribution is placed on $\theta$ and $\delta$ and then updated by conditioning on the experimental data (Higdon, Kennedy, Cavendish, Cafeo, \& Ryne, 2004). Figure 8 shows the flowchart of a typical Bayesian calibration model (Carmassi, Barbillon, Keller, Parent, \& Chiodetti). 


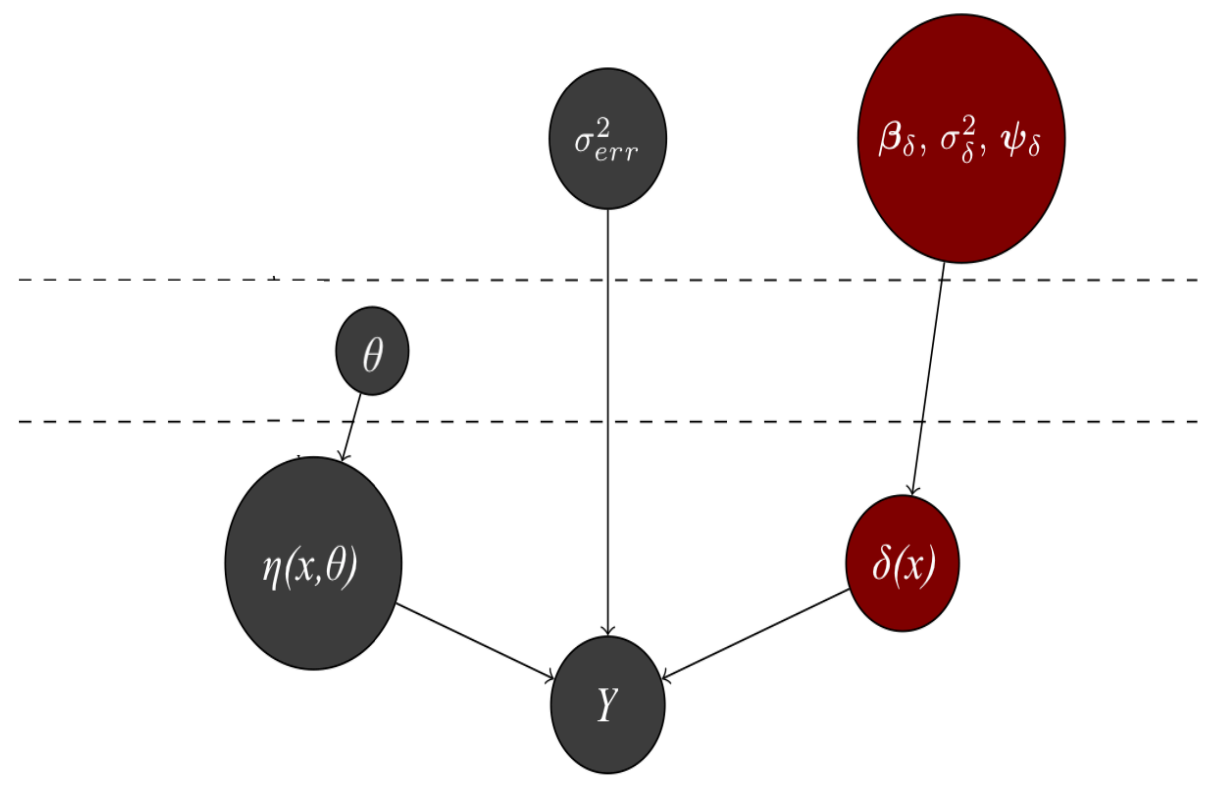

Figure 8: Bayesian Calibration Model

We implemented further simplifying assumptions to reduce the high-fidelity network and employed the use of a Gaussian Process to restore variability to the model that was lost in the reduction from the full-scale network. The most effective Gaussian Process for dynamic discrepancy is called Bayesian Smoothing Spline Analysis of Variance (BSS-ANOVA). The BSS-ANOVA procedure allows for variable and search direction selection (Reich, Storlie, \& Bondell, 2009). A multivariate normal distribution is assumed for the parameter set and Bayesian calibration is performed through comparison with data gathered from literature to determine the desired output distribution. Search direction sampling via a Sequential Monte Carlo (SMC) routine is used to search for variable sets that are able to match the data. Constructing the model in this manner allowed for decomposition of the variable selection into main effects and secondary effects. 


\subsection{Bayesian Smoothing Spline Analysis of Variance (BSS-ANOVA)}

A Gaussian Process is used to model the discrepancy function $\delta$. The Gaussian Process used is BSS-ANOVA (Reich, Storlie, \& Bondell, 2009). The BSS-ANOVA is a Gaussian Process that utilizes a special covariance function that uses the functional components from a functional ANOVA decomposition (Gu, 2012). One of the benefits of using a BBS-ANOVA GP is that it decomposes the stochastic differential equation into stochastic parameters $\beta$, and nonparametric deterministic basis functions $\emptyset$, thus reducing the stochastic differential equation to an ordinary differential equation for convenient uncertainty propagation. An additional benefit to using such a GP is that it scales linearly with the number of data points, and thus reduces computational cost.

The discrepancy function is represented as:

$$
\delta(x)=\beta_{0}+\sum_{r=1}^{R} \delta_{r}\left(x_{r}\right)+\sum_{r<r^{\prime}}^{R} \delta_{r, r^{\prime}}\left(x_{r}, x_{r^{\prime}}\right)
$$

It is assumed that $\beta_{0} \sim N\left(0, \varsigma_{0}^{2}\right)$, and that each main effect functional component is $\delta_{r} \sim G P\left(0, \varsigma_{r}^{2} K_{1}\right)$, for some variance parameters $\varsigma_{r}^{2}=0,1, \cdots, R$ and $K_{1}$ is the BSS-ANOVA covariance kernel described in Reich et al. That is:

$$
K_{1}\left(u, u^{\prime}\right)=B_{1}(u) B_{1}\left(u^{\prime}\right)+B_{2}(u) B_{2}\left(u^{\prime}\right)-\frac{1}{24} B_{4}\left(\left|u-u^{\prime}\right|\right)
$$

Where $B_{l}$ is the $l$-th Bernoulli polynomial. The covariance kernel operates on $[0,1]$. Higher order kernels are formed through tensor products of the first order kernel. Thus, the GP is constructed in a manner such that the functional domain of the GP is a Sobolev space of arbitrary order.

Storlie et al. demonstrated that every functional component of (10) can be decomposed into an orthogonal basis expansion (Storlie, Swiler, Helton, \& Sallaberry, 2009):

$$
\delta_{r}\left(x_{r}\right)=\sum_{l=1}^{\infty} \beta_{r, l} \emptyset_{l}\left(x_{r}\right) \quad \text { where } \beta_{r, l} \sim N\left(0, \tau_{r}^{2}\right)
$$


Where the $\emptyset_{l}$ terms are the eigenfunction in the Karhunen-Loeve (KL) expansion (Berlinet \& Thomas-Agnan, 2004). Figure 9 shows that the eigenfunctions $\emptyset_{l}$ start at high amplitude and low frequency and decrease in amplitude and increase frequency as their order increases.
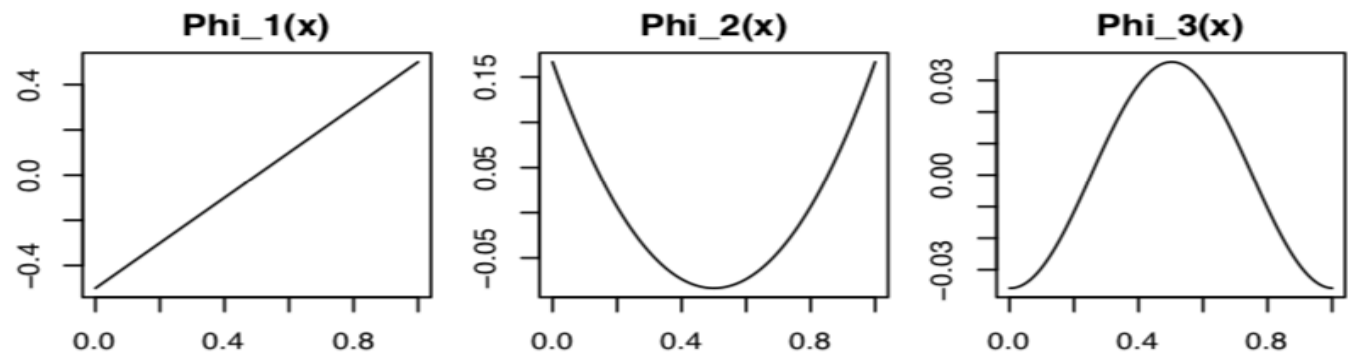

Phi_4(x)
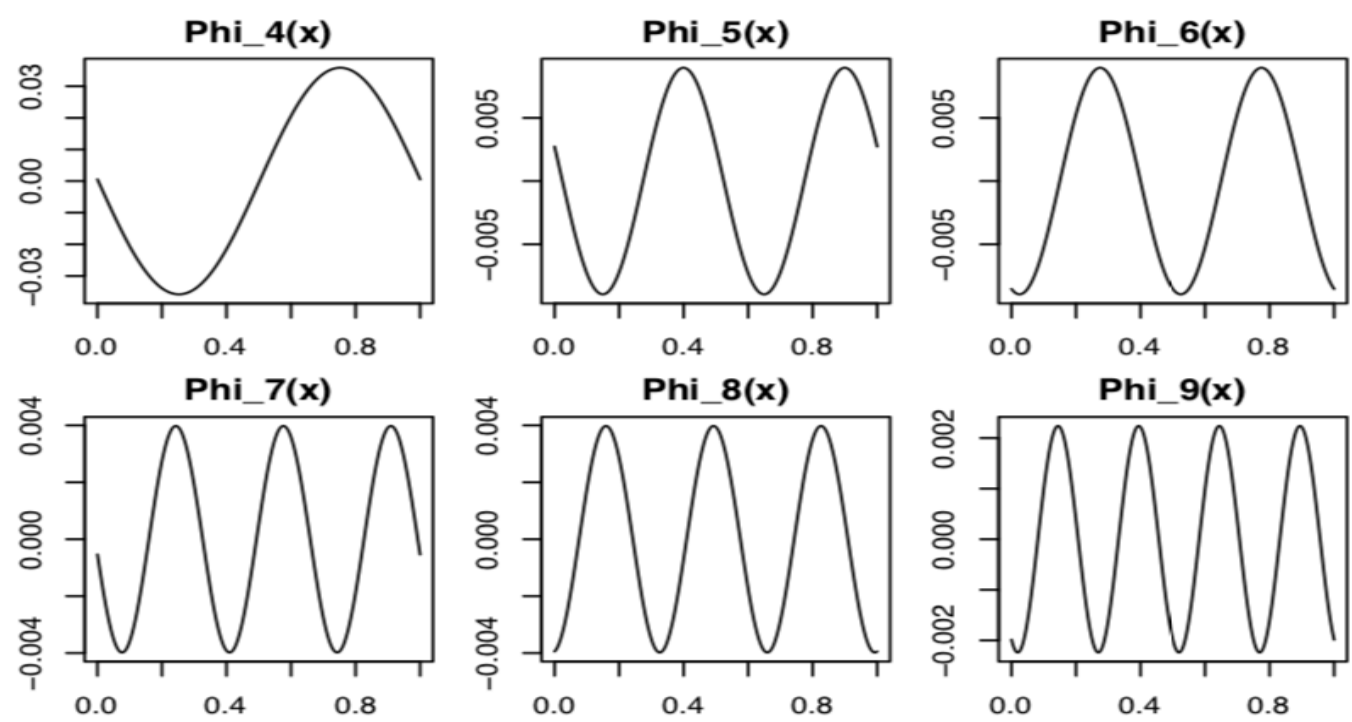

Figure 9: First nine eigenfunctions from the Karhunen-Loeve expansion for a main effect function from the BSSANOVA covariance. (adapted from (Storlie, Lane, Ryan, Gattiker, \& Higdon, 2015))

Functional ANOVA and Karhunen-Loeve decompositions yield an expansion of the form:

$$
\delta\left(x_{1}, x_{2}, \cdots\right)=\sum_{i} \beta_{1 i} \emptyset_{i}\left(x_{i}\right)+\sum_{j k} \beta_{j k} \emptyset_{j}\left(x_{j}\right) \emptyset_{k}\left(x_{k}\right)+\cdots \quad \text { where } \quad \beta_{r, l} \sim N\left(0, \tau_{r}^{2}\right)
$$

Hence, the functions, $\varnothing$, are nonparametric basis functions, orthogonal, and deterministic, and the coefficients $\beta$ are stochastic. The orthogonality of equation 12 allowed us to represent 
the model in such a way that interaction terms are only needed and added if and only if the data cannot be explained by the main effects alone. Thus, avoiding overlap from main effects and higher interaction terms. While the stochastic coefficients allowed us to have flexibility in our parameter search.

\subsection{Reduced Order Modeling Calibration with Dynamic Discrepancy}

Reducing the order of the high-fidelity model introduces uncertainty into the original model. Applying dynamic discrepancy terms to the model allows the behavior of the reduced order model to mimic that of the high-fidelity model. We incorporate the parameters and the discrepancy function within our model equations to express our system as:

$$
\frac{\partial z}{\partial t}=f_{s}(z, \theta, x(t), \delta(z, x(t) ; \beta))
$$

The model is then calibrated to the gathered experimental data. Fine tuning is then required in order to achieve adequate predictions. However, the process of fine tuning becomes an exercise of deciding between model accuracy and complexity. As the number of interactions increase within the discrepancy function, so does the computational complexity.

Calibration is thought of as a search for a distribution of model forms which may correspond to the experimental data given its uncertainty. We search for a distribution of $\{\theta\}$, and $\{\beta\}$ such that they yield model results consistent with the data. The calibration is accomplished using a Sequential Monte Carlo routine.

\subsection{Approximate Bayesian Computation using Sequential Monte Carlo Sampler}

In order to calibrate the model to the experimental data, a joint posterior distribution, $\Omega$, is needed for parameter sets $\{\theta\}$, and $\{\beta\}$. The posterior distribution is given as:

$$
\Omega(\{\theta\},\{\beta\} \mid \mathrm{Z}) \propto \mathcal{L}(Z \mid\{\theta\},\{\beta\}) \pi(\{\theta\},\{\beta\})
$$


Where $\mathrm{Z}$ is the observed data, $\mathcal{L}$ is the likelihood of the data given the parameters set, and $\pi$ is a prior distribution. By Bayes' theorem, we can express the posterior as:

$$
\Omega(\{\theta\},\{\beta\} \mid \mathrm{Z})=\frac{\mathcal{L}(Z \mid\{\theta\},\{\beta\}) \pi(\{\theta\},\{\beta\})}{\int \mathcal{L}(Z \mid\{\theta\},\{\beta\}) \pi(\{\theta\},\{\beta\}) \mathrm{d} \theta d \beta}
$$

Often, the likelihood term is expensive or impossible to calculate. Therefore, a Sequential Monte Carlo routine is used to calculate the posterior.

The posterior distribution is approximated by a collection of $N$ random samples, $\left\{Z_{n}^{(i)}\right\}_{i=1}^{N}$, called particles. At time 0 , the distribution $\Omega_{0}$, is chosen such that it is approximated by a uniform distribution $\eta_{0}$, and the weight of each particle is the same.

The initial weight of particle $i$ is given by:

$$
W_{0}^{(i)} \propto \frac{\Omega_{0}\left(z_{0}^{(i)}\right)}{\eta_{0}\left(z_{0}^{(i)}\right)}
$$

Such that $\sum_{j=1}^{N} W_{0}^{(j)}=1$

The effective sample size (ESS) is then calculated. The ESS is given as: (Liu, 2001)

$$
\operatorname{ESS}\left(W_{n}^{(i)}\right)=\left(\sum_{i=1}^{N}\left(W_{n}^{(i)}\right)^{2}\right)^{-1}
$$

The ESS is then compared to the number of particles divided by 2. If $E S S<\frac{N}{2}$, then it triggers a resampling step. Otherwise, the weights are updated, and the particles are moved from time $(n-1)$ to time $n$ by using a Markov kernel $K_{n}\left(z_{n-1}, z_{n}\right)$ which denotes the probability of moving from $z_{n-1}$ to $z_{n}$.

The choice of the Markov kernel then allows us to update the weights at the next time step by (Del Moral, Doucet, \& Jasra, 2011):

$$
W_{n}^{(i)} \propto W_{n-1}^{(i)} \frac{\Omega_{n}\left(z_{n-1}^{(i)}\right)}{\Omega_{n-1}\left(z_{n-1}^{(i)}\right)}
$$


Once the weights are updated, they are normalized and based on the value, the draw is either accepted and remains on the Markov Chain or it is rejected, and the particle "dies". Figure 10, shows the sampler routine of the Sequential Monte Carlo, with particles x, weights w, and number of particles $\mathrm{N}$.

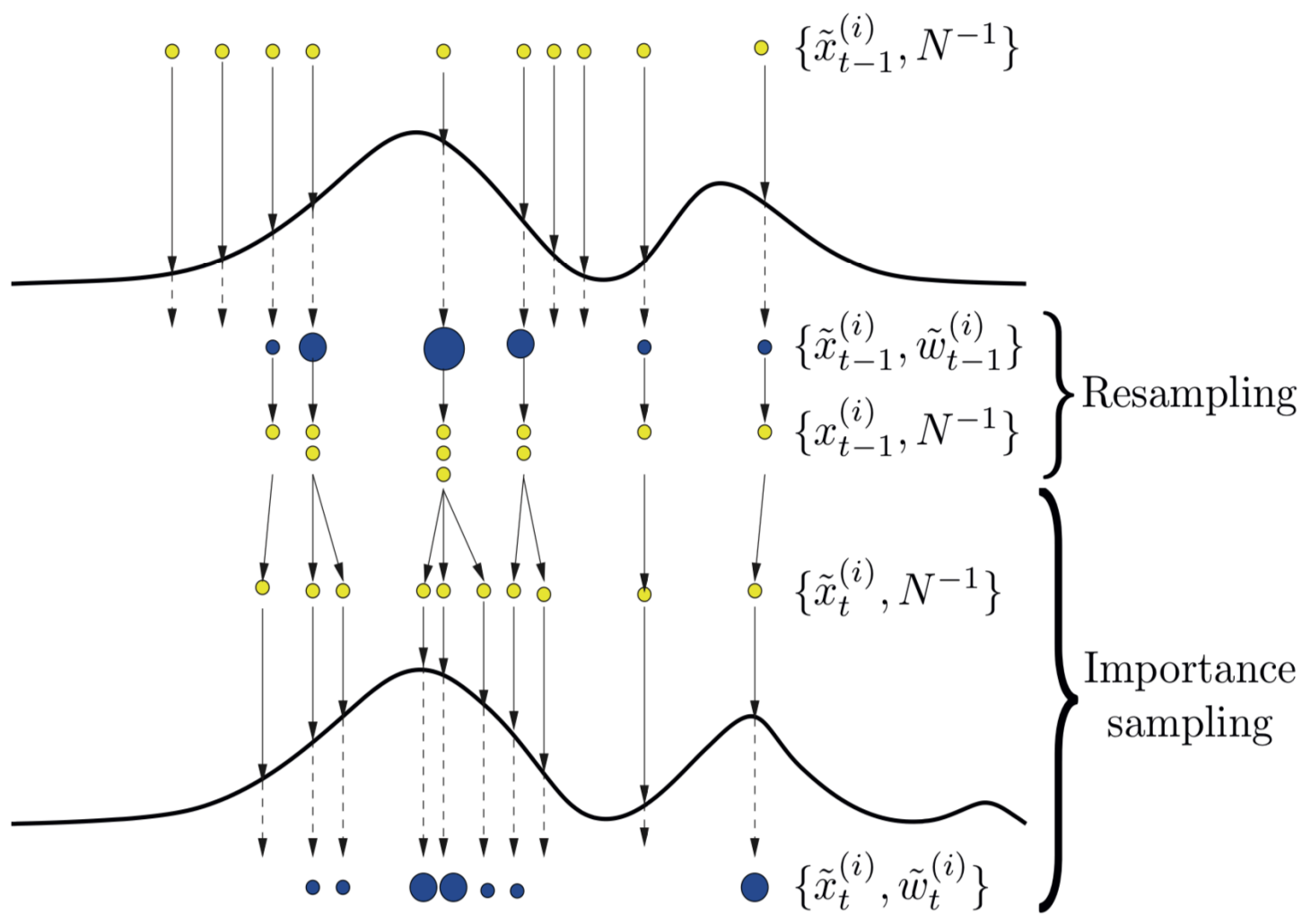

Figure 10: Sequential Monte Carlo Sampler with Importance Sampling and Resampling 


\section{Proposed Approach}

We use Azadi et al. comprehensive model to derive a reduced order model. This model is derived through simplifications made from prior knowledge of the process, such as catalytic dependent reactions/products, temperature dependent products, etc. The Fischer-Tropsch synthesis is also assumed to take place strictly in gas phase, this assumption is key to model the kinetics of the reaction.

\subsection{Reduced Order Model}

The reduction of Azadi's model can be justified through a prior knowledge of the catalyst used within the synthesis. Cobalt catalysts have very poor water-gas shift (WGS) activity (Lualdi, Logdberg, Regali, \& Boutennet, 2011), thus allowing us to eliminate equation 3. Alcohol yield and selectivity are low on Cobalt based catalyst (Shafer, Gnanamani, Graham, \& Yang, 2019), thus allowing us to eliminate equations 4 and 5. All catalysts suffer from carbon deposition to various extents, however we will ignore equations 6 and 7 as carbon deposition affecting the products will be built into the gathered data, and thus used when calibrating the reduced order model. We can therefore reduce Azadi et al. reaction network to the one shown in Figure 11.

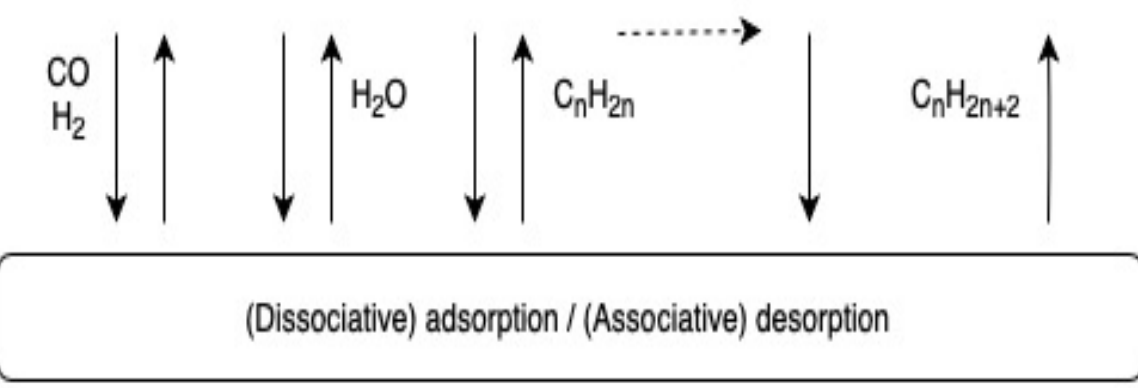

Figure 11: Reduced Order Model Reaction Network 
Since no states involving the catalyst need be retained in a reduced model because the catalyst state is not ultimately of interest, this reduced order model is appropriate for the study.

The reduced order model can therefore be expressed as a system of the following reactions:

Paraffins formation:

Olefins formation:

$$
\begin{array}{r}
(2 \mathrm{n}+1) \mathrm{H}_{2}+n \mathrm{CO} \rightarrow \mathrm{C}_{n} \mathrm{H}_{2 n+2}+n \mathrm{H}_{2} \mathrm{O} \\
2 n \mathrm{H}_{2}+n \mathrm{CO} \rightarrow C_{n} \mathrm{H}_{2 n}+n \mathrm{H}_{2} \mathrm{O}
\end{array}
$$

Equations 19 and 20 can and are expanded in this work to model hydrocarbon chains. There are countless possible species that result from the Fischer-Tropsch Synthesis; Through the Schulz-Flory equation, $x_{n}=(1-\alpha) \alpha^{n-1}$, we can show the selectivity of a particular carbonnumber species using the chain growth probability parameter $\alpha$. For example, as shown in Figure 12 , with a chain growth probability of .9 the selectivity of higher hydrocarbons decreases monotonically.

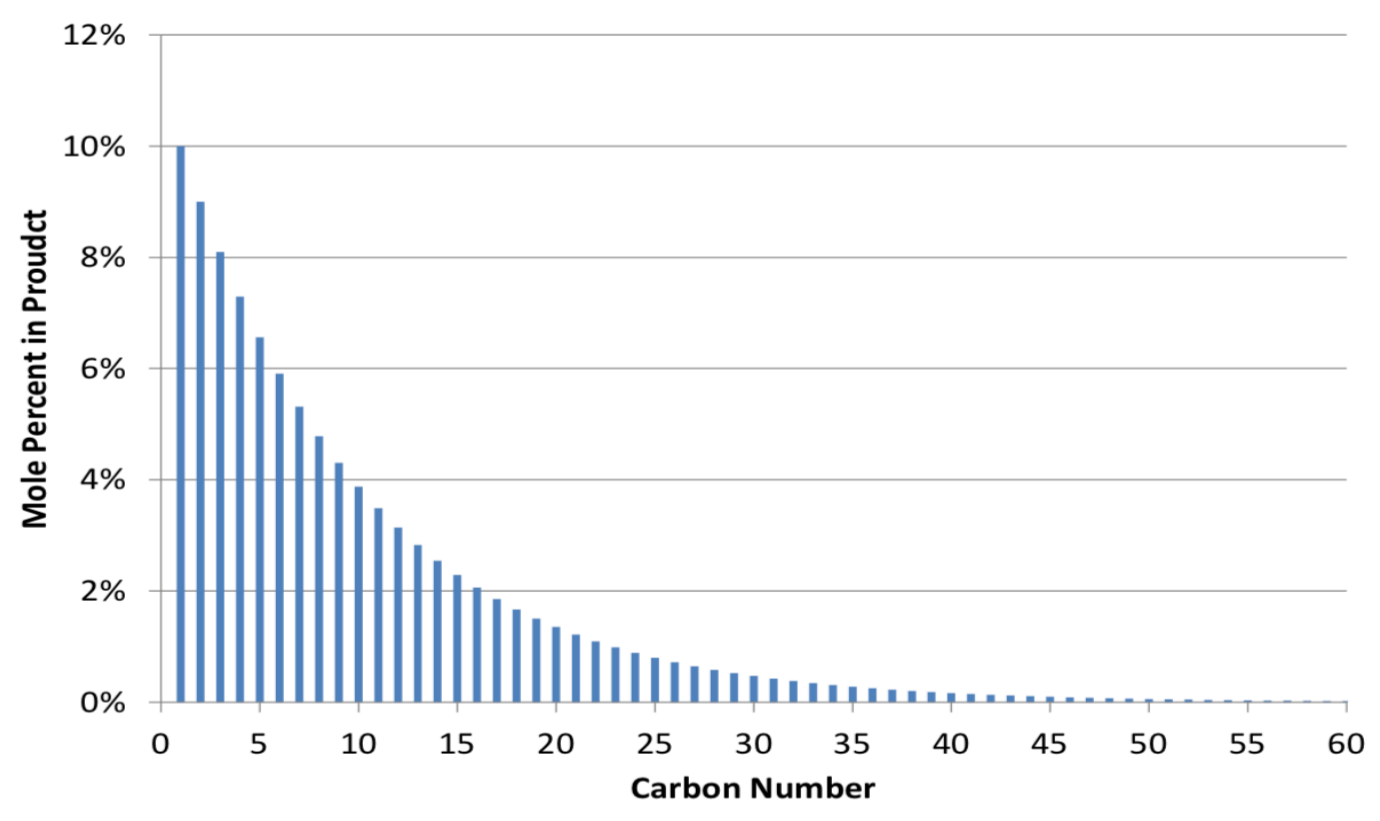

Figure 12: Anderson-Schulz-Flory (ASF) distribution in terms of mole percent, for $\alpha=0.9$ 
Figure 12 shows that expanding equations 19 and 20 past a certain carbon number would be counterproductive to a reduced order model approach.

Since we have data for up to 28 carbon numbers, we expand equations 19 and 20 such that we obtain:

Paraffins:

$$
\begin{gathered}
3 \mathrm{H}_{2}+\mathrm{CO} \longrightarrow \mathrm{CH}_{4}+\mathrm{H}_{2} \mathrm{O} \\
5 \mathrm{H}_{2}+2 \mathrm{CO} \rightarrow \mathrm{C}_{2} \mathrm{H}_{6}+2 \mathrm{H}_{2} \mathrm{O} \\
\cdots \\
57 \mathrm{H}_{2}+28 \mathrm{CO} \rightarrow \mathrm{C}_{28} \mathrm{H}_{58}+28 \mathrm{H}_{2} \mathrm{O}
\end{gathered}
$$

\section{Olefins:}

$$
\begin{gathered}
2 \mathrm{H}_{2}+\mathrm{CO} \longrightarrow \mathrm{CH}_{2}+\mathrm{H}_{2} \mathrm{O} \\
4 \mathrm{H}_{2}+2 \mathrm{CO} \rightarrow \mathrm{C}_{2} \mathrm{H}_{4}+2 \mathrm{H}_{2} \mathrm{O} \\
\cdots \\
56 \mathrm{H}_{2}+28 \mathrm{CO} \rightarrow \mathrm{C}_{28} \mathrm{H}_{56}+28 \mathrm{H}_{2} \mathrm{O}
\end{gathered}
$$

Through this expansion, we obtain the reaction rates:

$$
\begin{aligned}
& r_{1}=k_{1}\left[\left[C_{H_{2}}\right]^{3}\left[C_{C O}\right]-\frac{\left[C_{C_{4}}\right]\left[C_{\mathrm{H}_{2} \mathrm{O}}\right]}{\kappa_{1}}\right] \quad r_{2}=k_{2}\left[\left[C_{\mathrm{H}_{2}}\right]^{5}\left[C_{C O}\right]^{2}-\frac{\left[C_{C_{2} \mathrm{H}_{6}}\right]\left[C_{\mathrm{H}_{2} \mathrm{O}}\right]^{2}}{\kappa_{2}}\right] \\
& \ldots \quad r_{28}=k_{28}\left[\left[C_{H_{2}}\right]^{57}\left[C_{C O}\right]^{28}-\frac{\left[C_{C_{28} H_{58}}\right]\left[C_{H_{2} O}\right]^{28}}{\kappa_{28}}\right] \\
& r_{29}=k_{29}\left[\left[C_{\mathrm{H}_{2}}\right]^{2}\left[C_{\mathrm{CO}}\right]-\frac{\left[C_{\mathrm{CH}_{2}}\right]\left[C_{\mathrm{H}_{2} \mathrm{O}}\right]}{\kappa_{29}}\right] \quad r_{30}=k_{30}\left[\left[C_{\mathrm{H}_{2}}\right]^{4}\left[C_{C O}\right]^{2}-\frac{\left[C_{C_{2} \mathrm{H}_{4}}\right]\left[C_{\mathrm{H}_{2} \mathrm{O}}\right]^{2}}{\kappa_{30}}\right]
\end{aligned}
$$




$$
r_{56}=k_{56}\left[\left[C_{H_{2}}\right]^{56}\left[C_{C O}\right]^{28}-\frac{\left[C_{C_{28} H_{56}}\right]\left[C_{H_{2} O}\right]^{28}}{\kappa_{56}}\right]
$$

Where the equilibrium rate constants, $\kappa$, are expressed in terms of Gibbs Free

Energy, $\Delta G$, Ideal Gas Constant, $\mathrm{R}$, and Temperature, $\mathrm{T}$ :

$$
\kappa=\exp \left(\frac{\Delta S}{R}\right) \exp \left(\frac{-\Delta H}{R T}\right)=\exp \left(\frac{\Delta G}{R T}\right)
$$

And the reaction rate constants, $\mathrm{k}$, are expressed in terms of Activation Energy, $E_{a}$, preexponential factor, A, Ideal Gas Constant, R, and Temperature, T:

$$
k=\mathrm{A} * \exp \left(-\frac{E_{a}}{R T}\right)
$$

In turn, we created a system of differential equations:

$$
\begin{aligned}
& \frac{d\left[C_{\mathrm{H}_{2}}\right]}{d t}=\frac{\left[C_{\mathrm{H}_{2}}\right]_{0} * v_{0}-\left[C_{\mathrm{H}_{2}}\right] * v}{V}-\sum_{i=1}^{28}(2 * i+1) r_{i}-\sum_{j=1}^{28}(2 * j+1) r_{j+28} \\
& \frac{d\left[C_{C O}\right]}{d t}=\frac{\left[C_{C O}\right]_{0} * v_{0}-\left[C_{C O}\right] * v}{V}-\sum_{i=1}^{28} i * r_{i}-\sum_{j=1}^{28} j * r_{j+28} \\
& \frac{d\left[c_{\mathrm{H}_{2} \mathrm{O}}\right]}{d t}=\sum_{i=1}^{28} i * r_{i}+\sum_{j=1}^{28} j * r_{j+28} \\
& \frac{d\left[C_{C_{i} H_{2 i+2}}\right]}{d t}=r_{i} \quad \text { for } 1 \leq i \leq 28 \\
& \frac{d\left[c_{C_{j} H_{2 j}}\right]}{d t}=r_{j+28} \quad \text { for } 1 \leq j \leq 28
\end{aligned}
$$

Since it has been shown in literature that Methane does not conform well to the ASF distributions, we include a discrepancy term within that reaction. Since Methylene is usually assumed to be a rate limiting reaction, we included a discrepancy term within that reaction as well. 
Ethane, Ethylene, and Propene are also fitted with discrepancy terms as according to the ASF distribution these are the most likely products to be produced through Fischer-Tropsch. Also, according to Schouten et al. in his thesis "Quantum Chemical and Microkinetic Modeling of the Fischer-Tropsch Reaction" these products are the most unstable. (Schouten, Hensen, \& van Santen, 2015).

The dynamic discrepancy terms, $\delta$, are placed within the equilibrium and rate constants, $\kappa$ and $\mathrm{k}$ respectively, allowing us to display the functions as

$$
\begin{aligned}
& \kappa_{i}=\kappa_{i, 0} * \exp \left(\delta_{\kappa_{i}}(P ; \beta)\right) \\
& k_{i}=k_{i, 0} * \exp \left(\delta_{k_{i}}(P ; \beta)\right)
\end{aligned}
$$

This in turn allows us to write our system of differential equations as:

$$
\begin{aligned}
& \frac{d\left[C_{H_{2}}\right]}{d t}=\frac{\left[C_{H_{2}}\right]_{0} * v_{0}-\left[C_{H_{2}}\right] * v}{V}-3 r_{1}^{\prime}-5 r_{2}^{\prime}-3 r^{\prime}{ }_{29}-5 r^{\prime}{ }_{30}-7 r^{\prime}{ }_{31}-\sum_{i=3}^{28}(2 * i+1) r_{i}-\sum_{j=4}^{28}(2 * j+1) r_{j+28} \\
& \frac{d\left[C_{C O}\right]}{d t}=\frac{\left[C_{C o}\right]_{0} * v_{0}-\left[C_{C O}\right] * v}{V}-r^{\prime}{ }_{1}-2 r^{\prime}{ }_{2}-r^{\prime}{ }_{29}-2 r^{\prime}{ }_{30}-3 r^{\prime}{ }_{31}-\sum_{i=3}^{28} i * r_{i}-\sum_{j=4}^{28} j * r_{j+28} \\
& \frac{d\left[C_{\mathrm{H}_{2} \mathrm{O}}\right]}{d t}={r^{\prime}}_{1}+2{r^{\prime}}_{2}+{r^{\prime}}_{29}+2{r^{\prime}}_{30}+3{r^{\prime}}_{31}+\sum_{i=3}^{28} i * r_{i}+\sum_{j=1}^{28} j * r_{j+28} \\
& \frac{d\left[C_{C_{4}}\right]}{d t}=r_{1}^{\prime} \\
& \frac{d\left[C_{C_{2} H_{6}}\right]}{d t}=r_{2}^{\prime} \\
& \frac{d\left[C_{C_{i} H_{2 i+2}}\right]}{d t}=r_{i} \quad \text { for } 3 \leq i \leq 28 \\
& \frac{d\left[C_{C_{2}}\right]}{d t}=r^{\prime}{ }_{29} \\
& \frac{d\left[C_{C_{2} \mathrm{H}_{4}}\right]}{d t}=r^{\prime}{ }_{30}
\end{aligned}
$$


$\frac{d\left[c_{C_{3} H_{6}}\right]}{d t}=r_{31}^{\prime}$

$\frac{d\left[c_{C_{j} H_{2 j}}\right]}{d t}=r_{j} \quad$ for $32 \leq j \leq 56$

where the r primes are given as:

$r_{1}^{\prime}=k_{1} * \exp \left(\delta_{k_{1}}(P ; \beta)\right)\left[\left[C_{H_{2}}\right]^{3}\left[C_{C O}\right]-\frac{\left[C_{C H_{4}}\right]\left[C_{H_{2} O} O\right.}{\kappa_{1} * \exp \left(\delta_{\kappa_{1}}(P ; \beta)\right)}\right]$

$r_{2}^{\prime}=k_{2} * \exp \left(\delta_{k_{2}}(P ; \beta)\right)\left[\left[C_{H_{2}}\right]^{5}\left[C_{C O}\right]^{2}-\frac{\left[C_{C_{2} H_{6}}\right]\left[C_{H_{2} o}\right]^{2}}{\kappa_{2} * \exp \left(\delta_{\kappa_{2}}(P ; \beta)\right.}\right]$

$r_{29}^{\prime}=k_{29} * \exp \left(\delta_{k_{29}}(P ; \beta)\right)\left[\left[C_{H_{2}}\right]^{2}\left[C_{C O}\right]-\frac{\left[C_{C_{2}}\right]\left[C_{H_{2} O}\right]}{\kappa_{29} * \exp \left(\delta_{\kappa_{29}}(P ; \beta)\right)}\right]$

$r_{30}^{\prime}=k_{30} * \exp \left(\delta_{k_{30}}(P ; \beta)\right)\left[\left[C_{H_{2}}\right]^{4}\left[C_{C O}\right]^{2}-\frac{\left[C_{C_{2} H_{4}}\right]\left[C_{H_{2} O}\right]^{2}}{\kappa_{30} * \exp \left(\delta_{\kappa_{30}}(P ; \beta)\right)}\right]$

$r^{\prime}{ }_{31}=k_{31} * \exp \left(\delta_{k_{31}}(P ; \beta)\right)\left[\left[C_{H_{2}}\right]^{6}\left[C_{C O}\right]^{3}-\frac{\left[C_{C_{3} H_{6}}\right]\left[C_{H_{2} O}\right]^{3}}{\kappa_{32} * \exp \left(\delta_{\kappa_{31}}(P ; \beta)\right)}\right]$

thus giving us a total of 57 differential equations, with five discrepancy terms. Each $\delta$ discrepancy function is then composed of five one-way interactions and two two-way interactions. The two-way interactions corresponding to methane-methylene, and ethaneethylene.

The chosen two-way interaction terms were added one at a time. That is, the interactions were determined empirically and added after consulting with the literature on hydrocarbon chain propagations, and their effect on one another, much like the decision to include discrepancy functions within the reactions for certain products. For example, it was determined that methanemethylene terms were not sufficient in reducing the error, so the ethane-ethylene two-way interaction was incorporated. The general form of the discrepancy functions used is:

$$
\delta_{\kappa}=\sum_{i=1}^{5} \beta_{i} \emptyset_{1}\left(x_{i}\right)+\beta_{(1,1,2,1)} \emptyset_{1}\left(x_{1}\right) \emptyset_{1}\left(x_{2}\right)+\beta_{(3,1,4,1)} \emptyset_{1}\left(x_{3}\right) \emptyset_{1}\left(x_{4}\right)
$$




$$
\delta_{k}=\sum_{i=1}^{5} \beta_{i} \emptyset_{1}\left(x_{i}\right)+\beta_{(1,1,2,1)} \emptyset_{1}\left(x_{1}\right) \emptyset_{1}\left(x_{2}\right)+\beta_{(3,1,4,1)} \emptyset_{1}\left(x_{3}\right) \emptyset_{1}\left(x_{4}\right)
$$

\subsection{Simulation}

Simulations were conducted to test the capability of the reduced order model to predict the product distribution that results due to the Fischer-Tropsch synthesis. Using data gathered from literature, the Sequential Monte Carlo routine looks for the posterior distribution of the model and discrepancy parameters. For the base case, (non-discrepancy case), to restrict the region searched initial model parameters were estimated using Tian et al. (Tian, et al., 2010) Kinetic Monte Carlo study over an iron catalyst. This allowed for a faster convergence of the Sequential Monte Carlo routine. Once the posterior of these parameters was obtained, the data was used to calibrate the discrepancy case. 


\section{Results}

The model simulated a continuously stirred tank reactor (CSTR). Simulations were performed to determine the validity of the use of dynamic discrepancy within the reduced order model. Convergence is analyzed in the later sections. The model equations are then used to simulate a Plug Flow Reactor, with initial conditions similar to the CSTR ROM.

\subsection{Reduced Order Model Realizations}

Simulations were conducted to determine the performance of the reduced order model at lab scale. Visconti's data at 503.15-508.15 K and at 20-25 bar was used for calibration and validation (Visconti, Tronconi, Lietti, Zennaro, \& Forzatti, 2006). The high-fidelity model case was simulated by using the data points pertaining to $503.15 \mathrm{~K}$ and 20 bar. A successful calibration requires adequate coverage of the predictions achieved through the high-fidelity model case.

A well-mixed reactor and isothermal behavior are assumed. The geometry and initial conditions are also taken from Visconti and Fontenelle's work (Fontenelle Jr \& Fernandes, 2011). Initially $\mathrm{CO}$ and $\mathrm{H} 2$ were inlet to the system at a 5:1 molar ratio. The outflow depended on the concentration of gas in the volume. The simulation was conducted for 30 seconds, as that seemed adequate to achieve steady state.

10,000 samples/particles were used during the Sequential Monte Carlo routine. This allowed for resampling to be introduced should the particle "die" or steer away from the prior. The baseline ROM was run without any discrepancy terms. Figure 13 show the reactants behavior with and without discrepancy terms. 

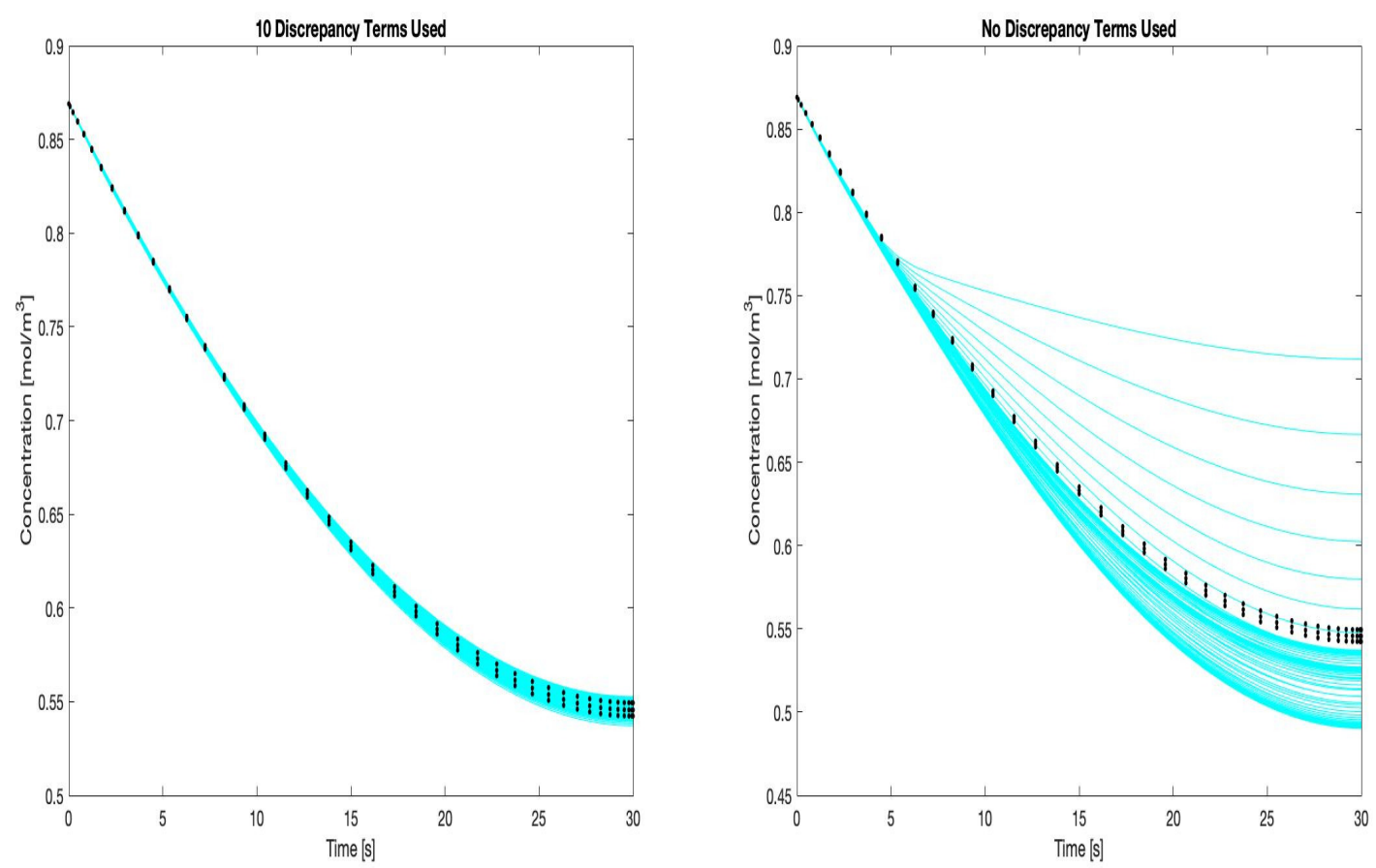

(a) CO ROM Realizations: 10 Discrepancy Terms Used vs. No Discrepancy Terms Used
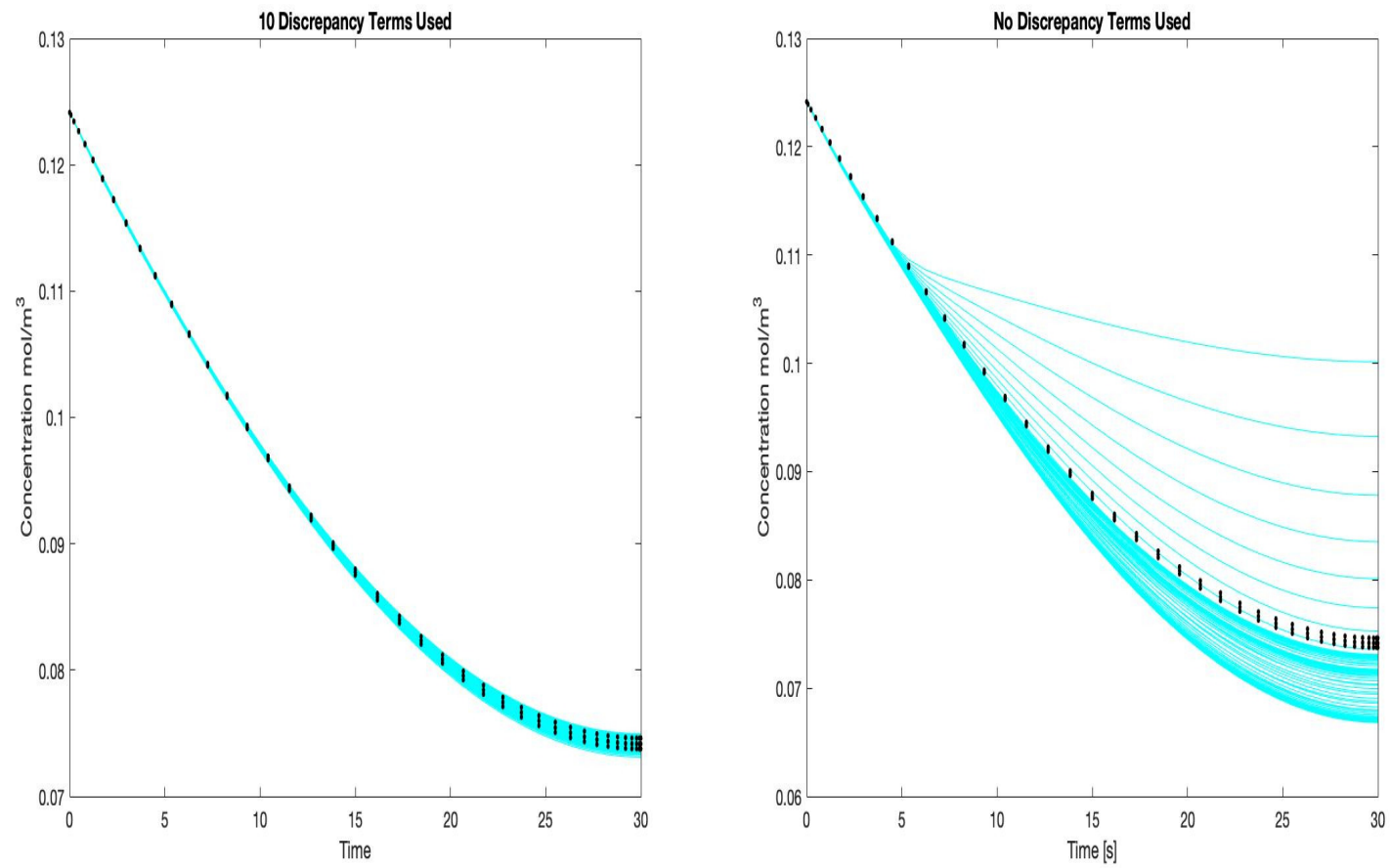

(b) $\mathrm{H}_{2}$ ROM Realizations: 10 Discrepancy Terms Used vs. No Discrepancy Terms Used

Figure 13: ROM Realizations vs experimental data for reactants with and without discrepancy terms: (a) $\mathrm{CO}$ (b) $\mathrm{H}_{2}$ 
From Figure 13, we can see the need for discrepancy terms. The graphs to the right show the coverage of the ROM without discrepancy terms. The coverage has a wide range due to the uncertainty introduced when eliminating the intermediate equations. The tighter ROM Realizations present on the left-hand side are given due to the error quantification introduced through the discrepancy terms. Figure 12 shows the predicted product distribution obtained with and without discrepancy terms.
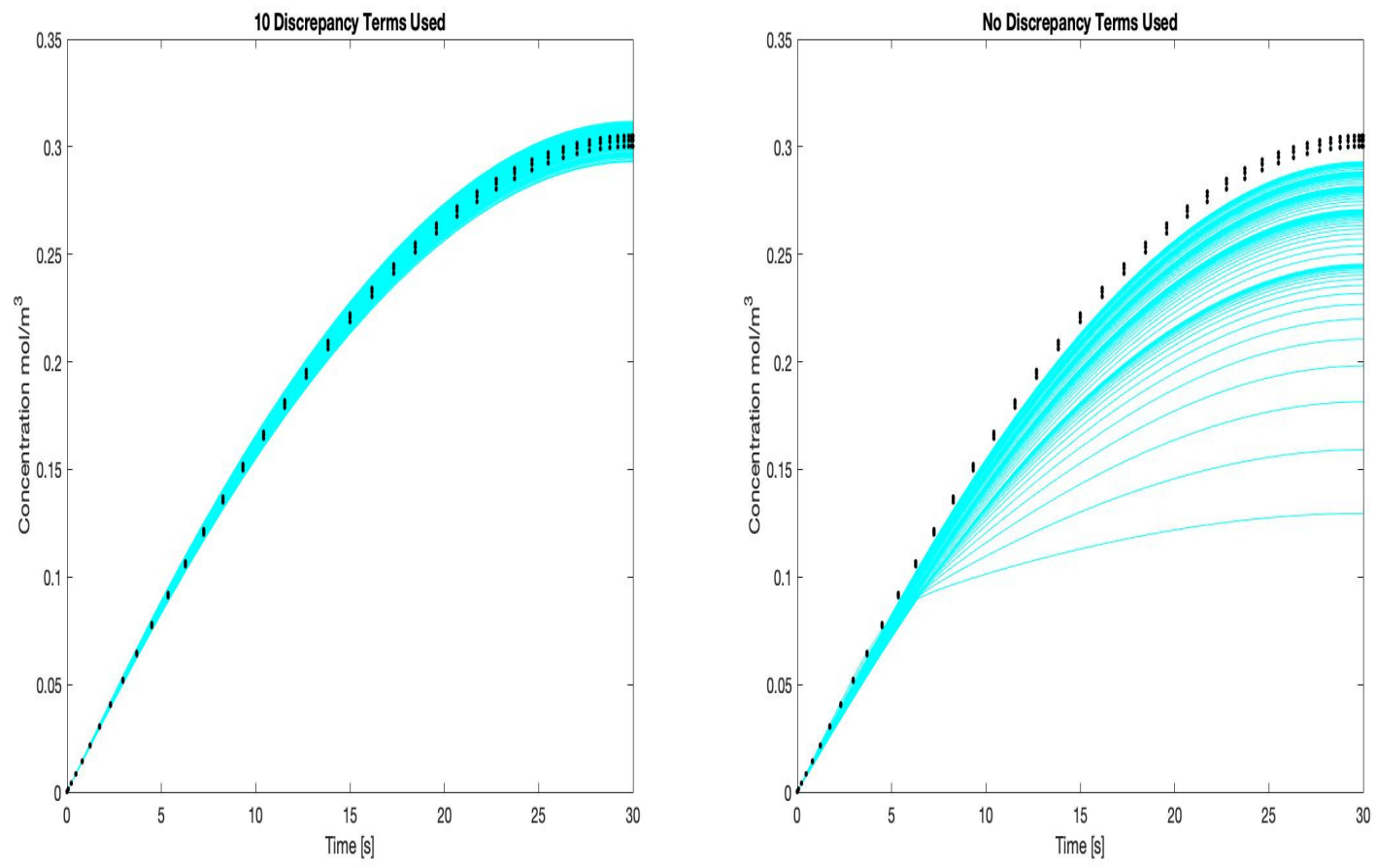

(a) $\mathrm{H}_{2} \mathrm{O}$ ROM Realizations: 10 Discrepancy Terms Used vs. No Discrepancy Terms Used 

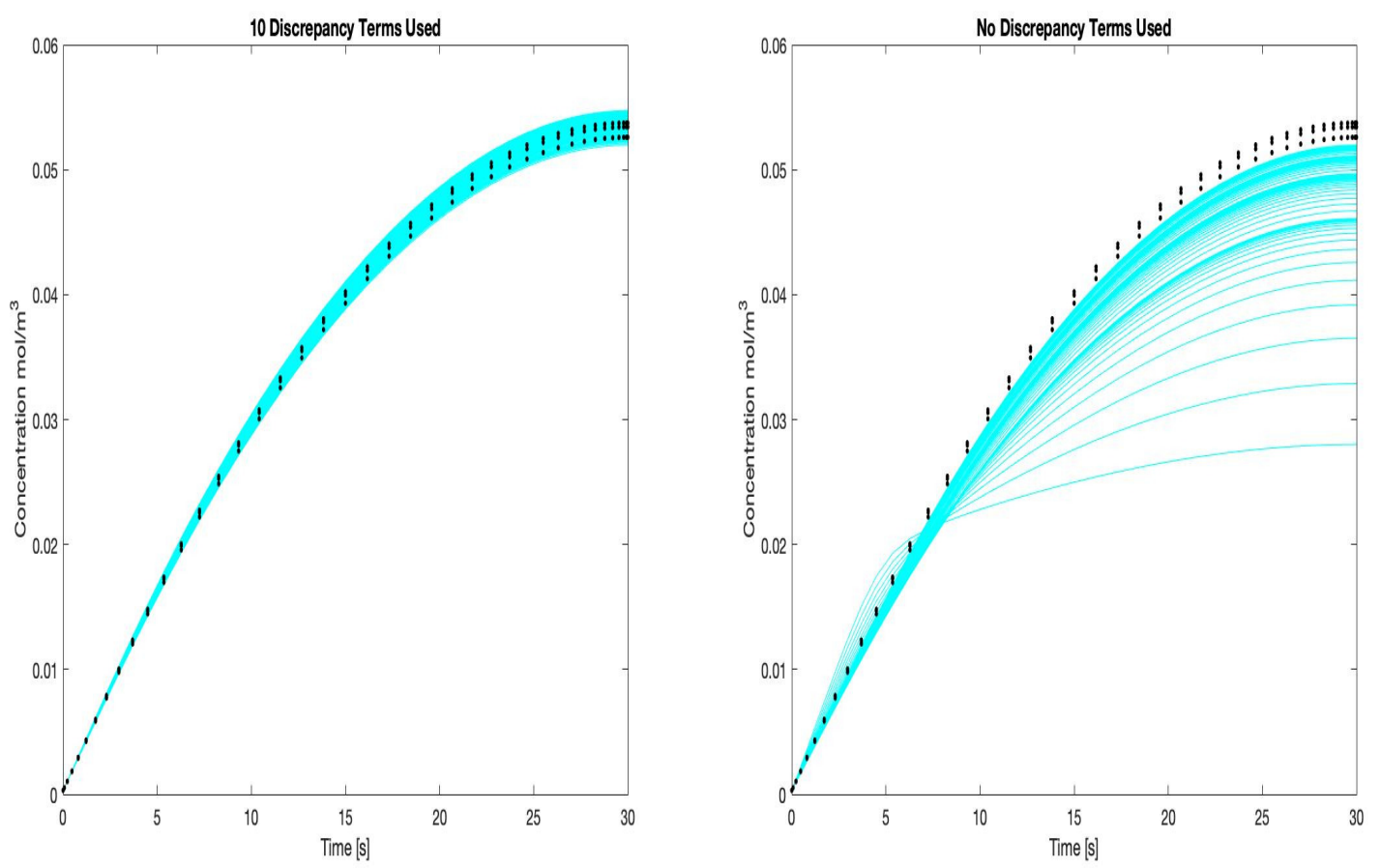

(b) C1-C10 ROM Realizations: 10 Discrepancy Terms Used vs. No Discrepancy Terms Used
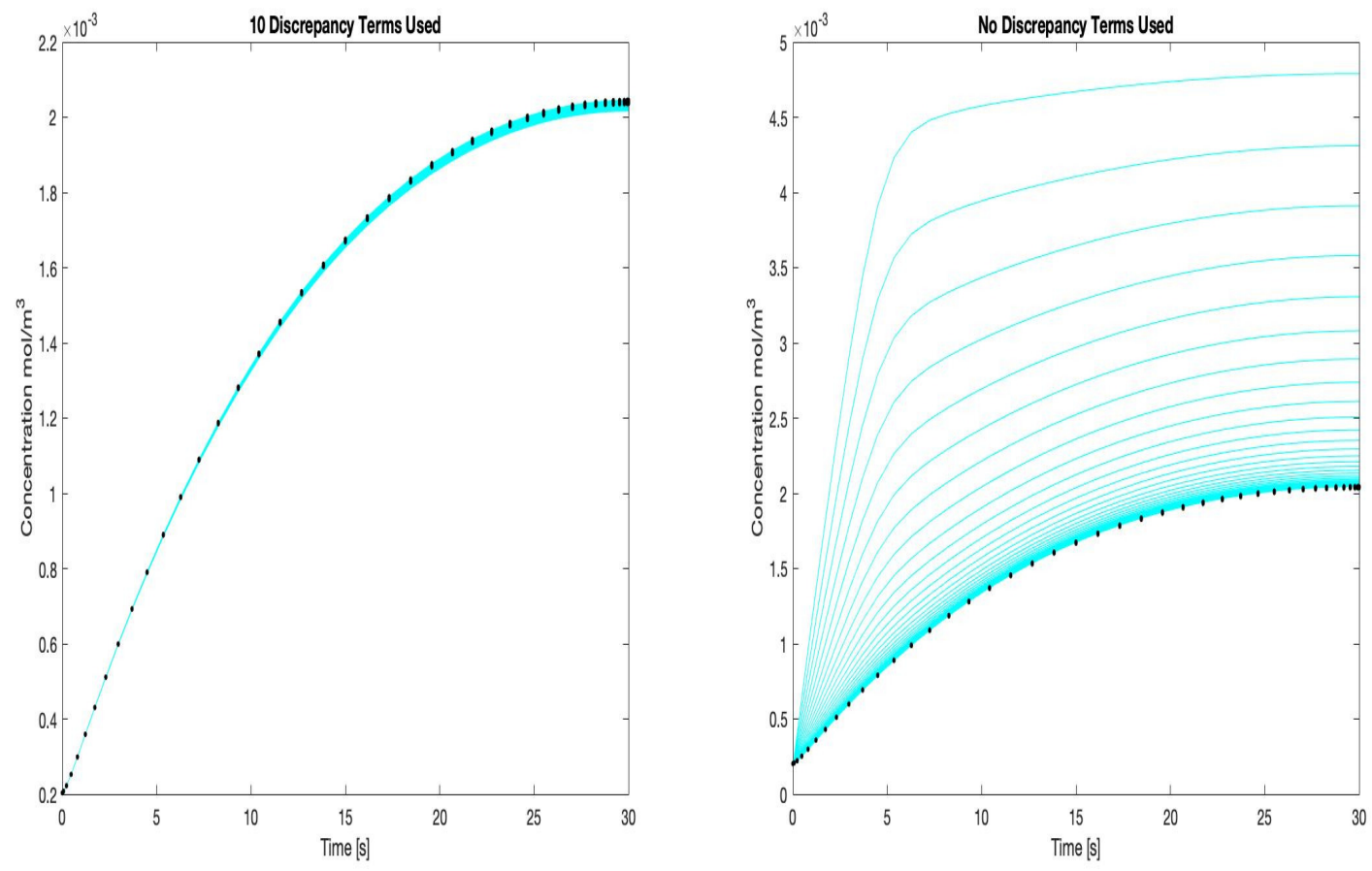

(c) C11-C20 ROM Realizations: 10 Discrepancy Terms Used vs. No Discrepancy Terms Used 

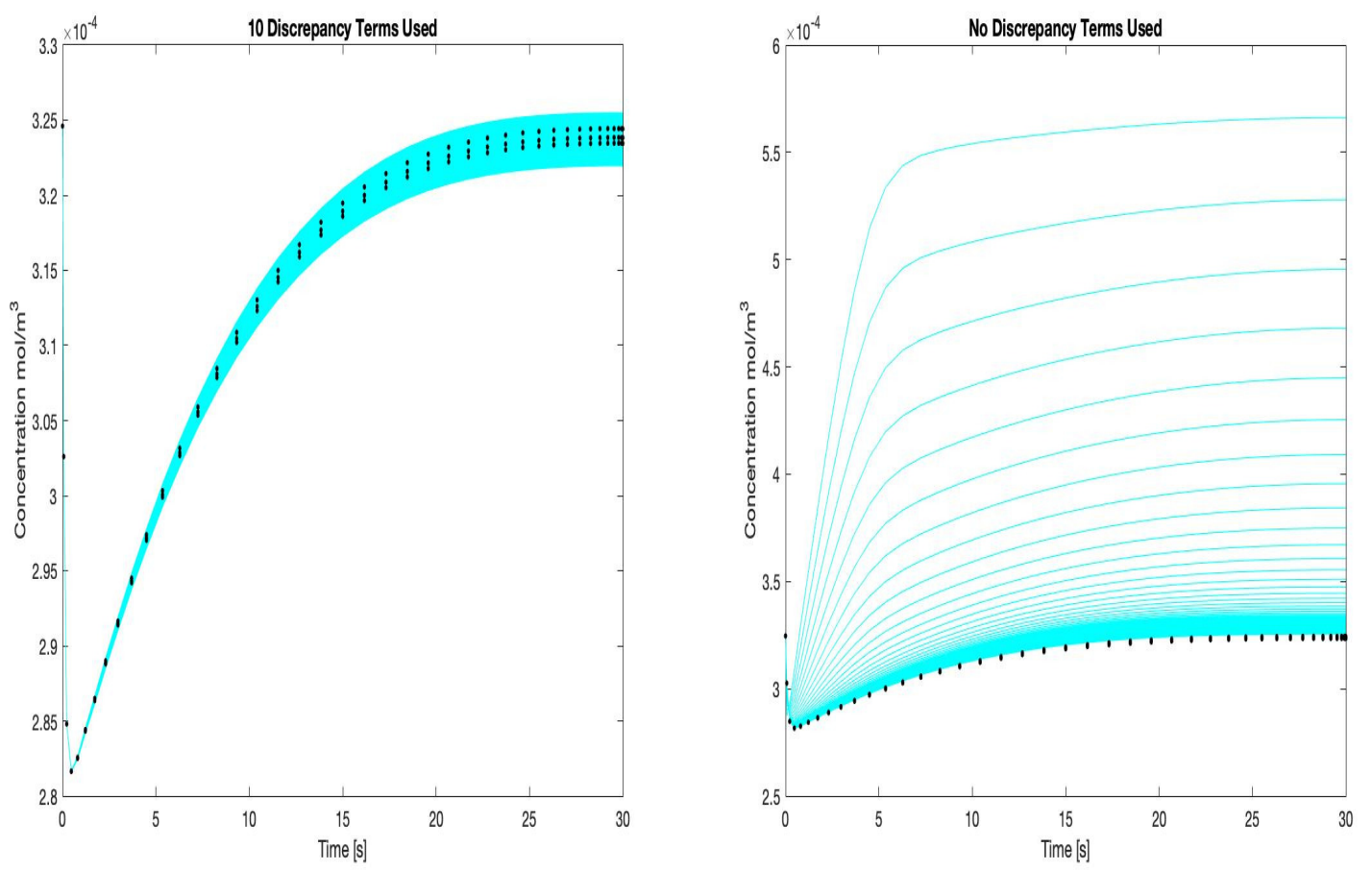

(d) C21-C30 ROM Realizations: 10 Discrepancy Terms Used vs. No Discrepancy Terms Used

Figure 14: ROM Realizations vs experimental data for products with and without discrepancy terms: (a) $\mathrm{H}_{2} \mathrm{O}$ (b) C1-C10 (c) C11-C20 (d) C21-C30

Due to the nature of these concentrations, the carbon numbers were lumped together to make better and more accurate graphs. Since theoretically, methane, ethane, ethaline, essentially carbon numbers up to five are the most produced during the synthesis, discrepancy terms were used within these five reaction rates. Placing these discrepancy terms in these first five reactions propagated and corrected the error in later reactions. Most visibly seen corrections happen for carbon numbers greater than 20 as well as the $\mathrm{H}_{2} \mathrm{O}$ production. This might be explained by the fact that the introduced discrepancy terms at the beginning of the reaction cascade and correct the later hydrocarbons produced. 


\subsection{Convergence and Statistics of Simulation}

Convergence of the Sequential Monte Carlo routine is guaranteed by Del Moral et al. for an arbitrary Kernel for weight updates. The proof is an extension of the functional fluctuation theorem of the local errors associated with the mean field particle approximation and employs the use of the functional central limit theorem.

Consequentially, we can be sure that the model converged when the posterior distribution reaches a point in which at time $(n-1)$ does not differ from the posterior distribution at time $n$. That is, the SMC routine reaches an invariant space.

Confirmation of the converged posterior distribution was verified statistically for both the discrepancy and non-discrepancy case. Tables 2 and 3 in the appendix show the mean and standard deviation of all parameters used within the models.

\subsection{Plug Flow Reactor}

This section aims at propagating the error of the reduced order model of the continuously stirred tank reactor to the model for a plug flow reactor, through the simulation of the PFR as a series of CSTRs.

The posterior distribution obtained from the CSTR case was used in the case of modeling the plug flow reactor. Each plug follows the same initial conditions as described in section 4.1, as well as the assumption of being isothermal and well-mixed.

Figures 15 and 16 compare the high-fidelity data to that of the ROM realizations for both products and reactants. 


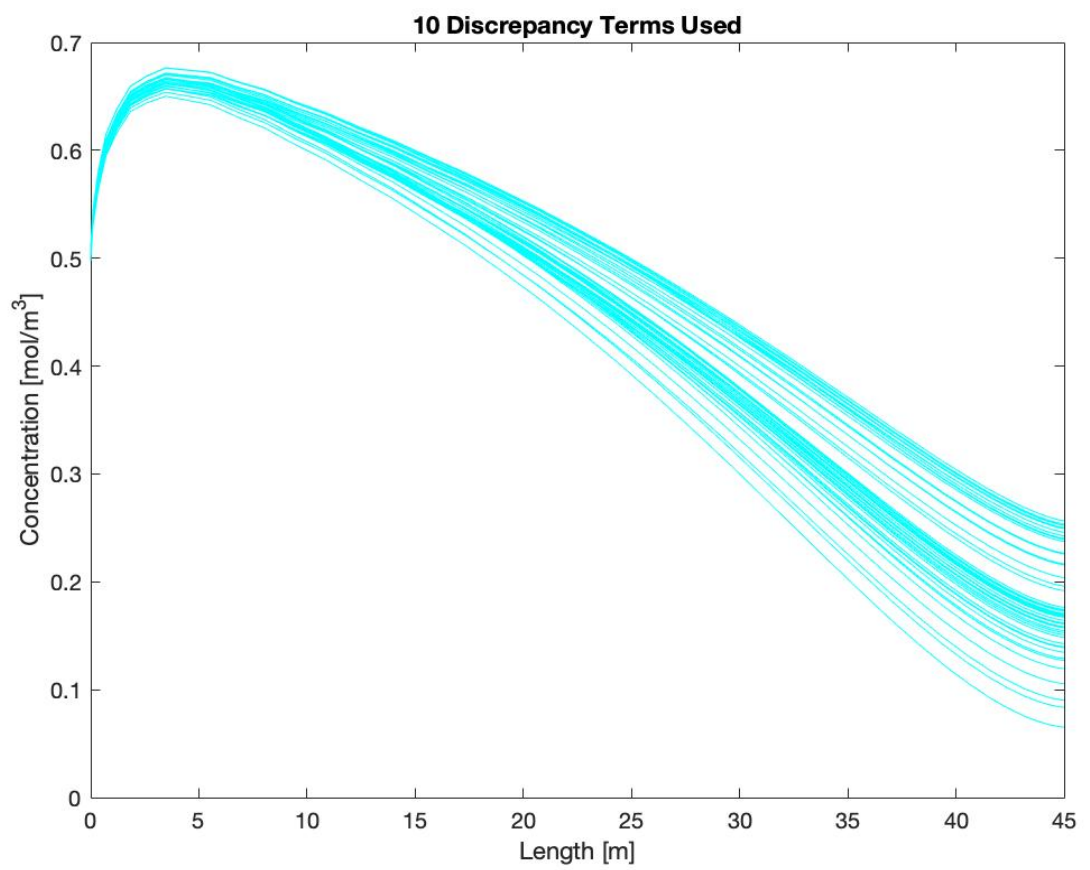

(a) CO PFR Realizations with 10 Discrepancy Terms Used

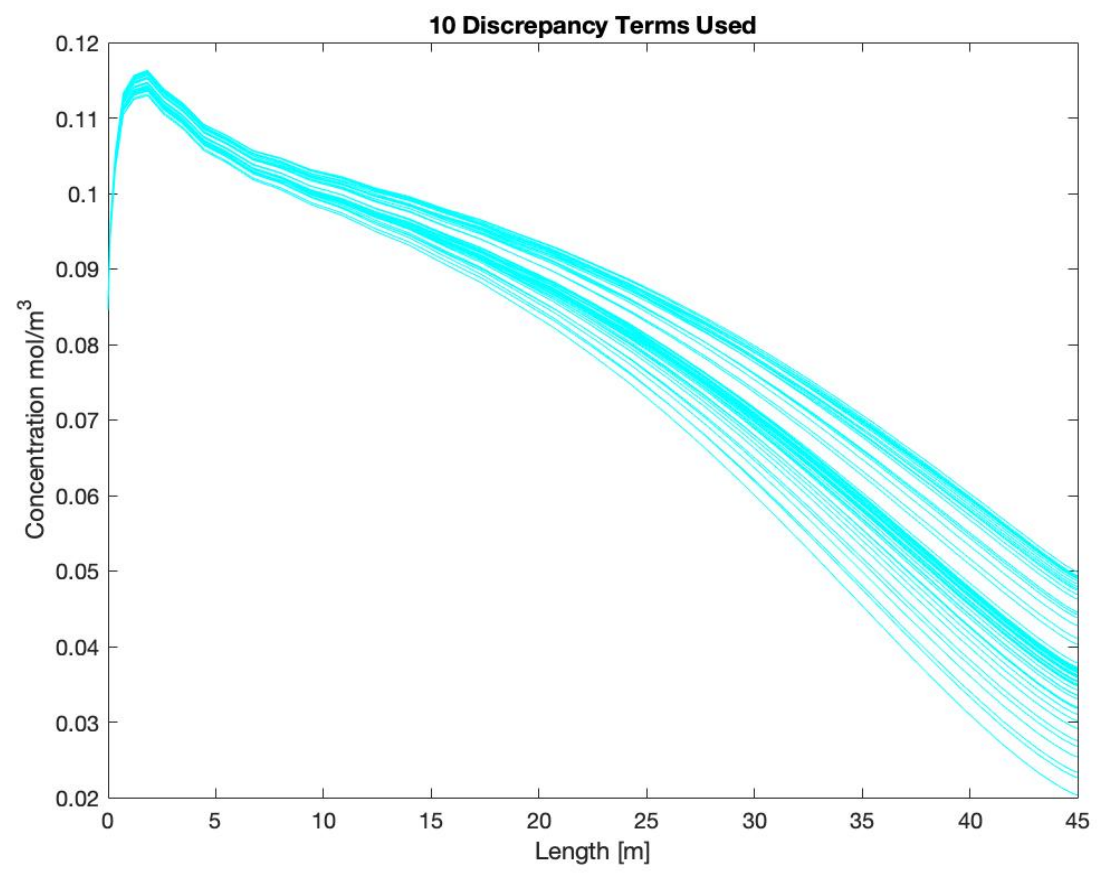

(b) $\mathrm{H}_{2}$ PFR Realizations with 10 Discrepancy Terms Used

Figure 15: PFR ROM Realizations for reactants: (a) $\mathrm{CO}$ (b) $\mathrm{H}_{2}$ 


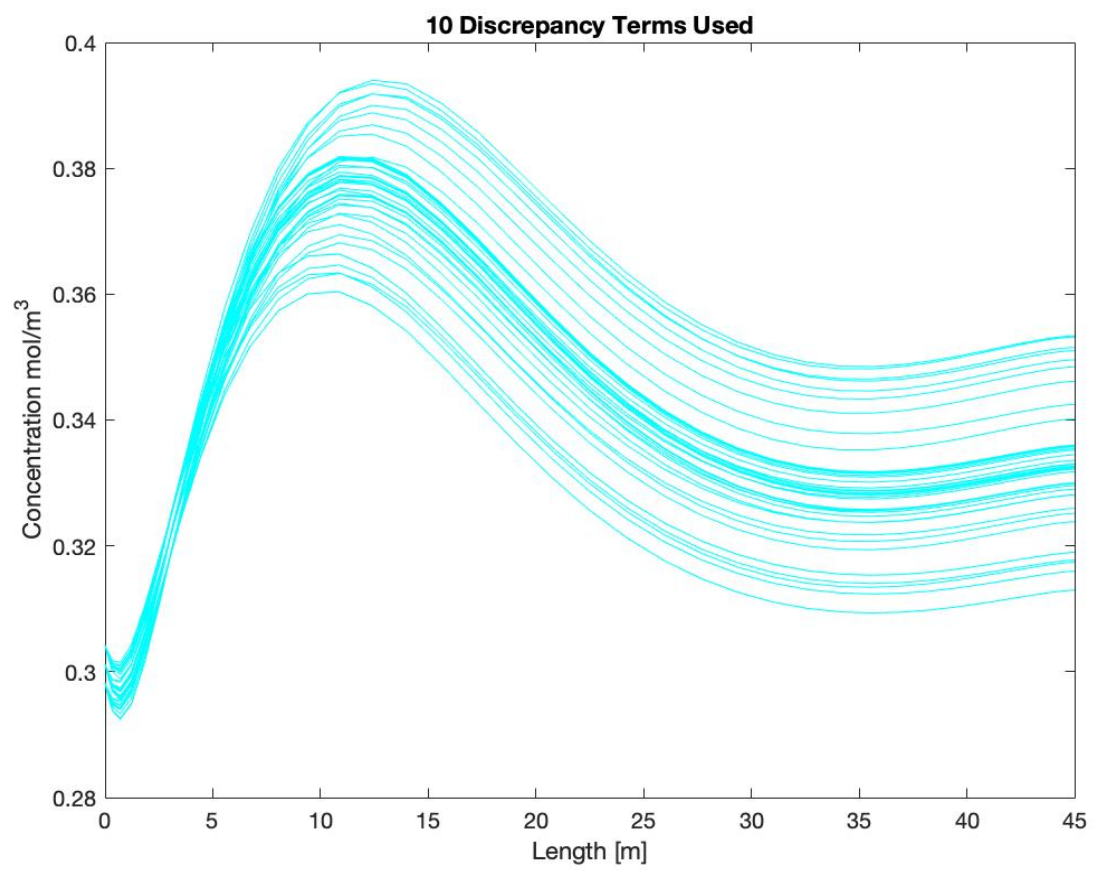

(a) $\mathrm{H}_{2} \mathrm{O}$ PFR Realizations with 10 Discrepancy Terms Used

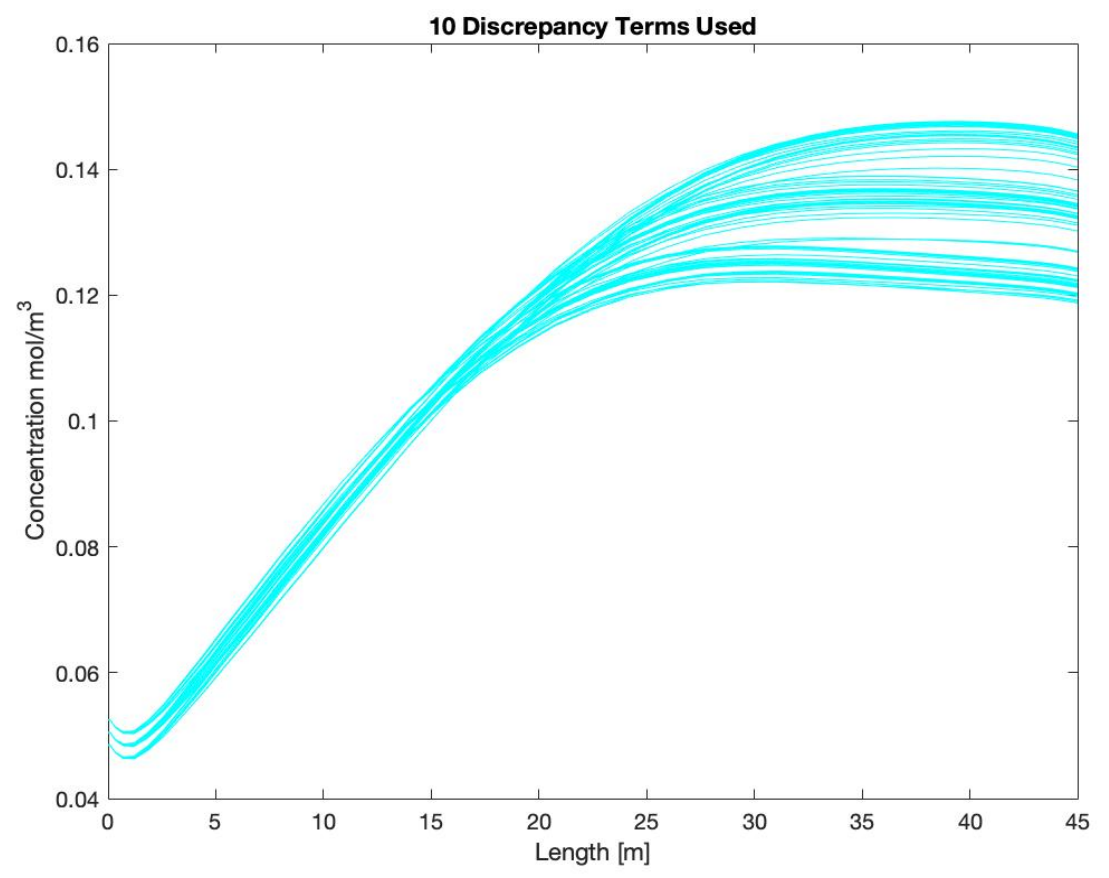

(b) C1-C10 PFR Realizations with 10 Discrepancy Terms Used 


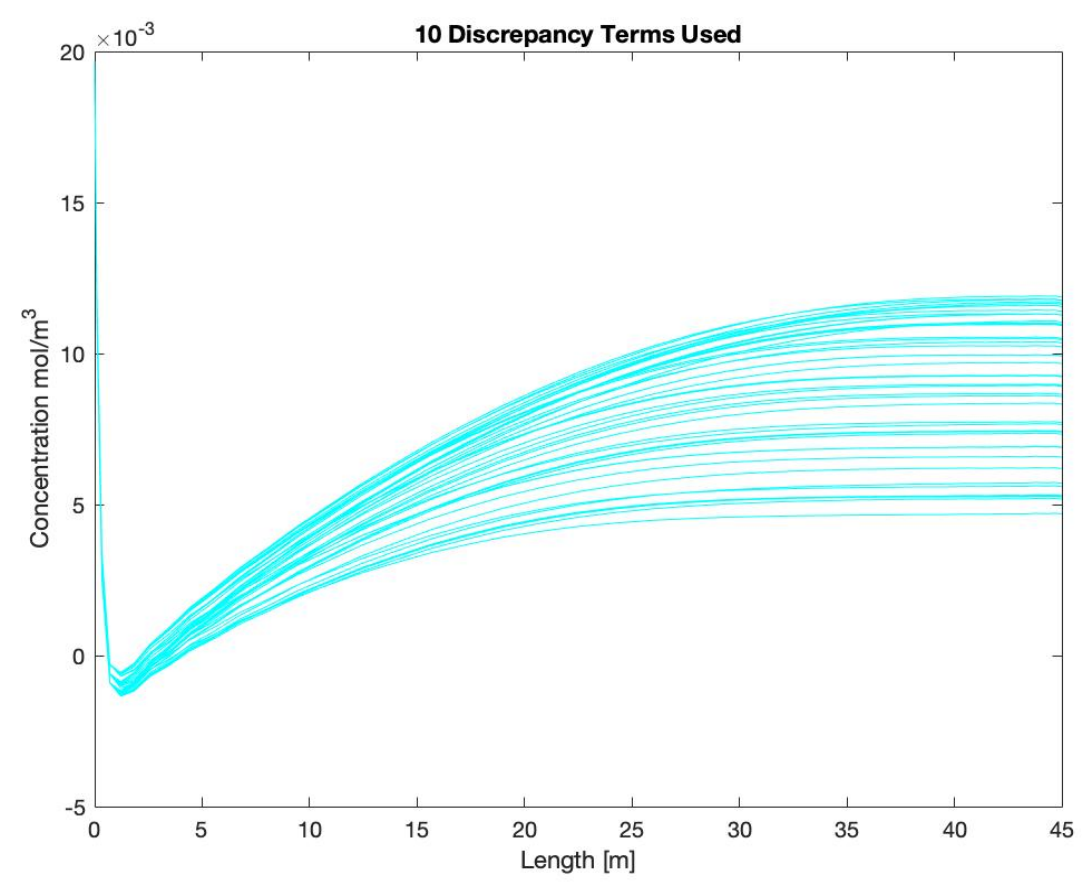

(c) C11-C20 PFR Realizations with 10 Discrepancy Terms Used

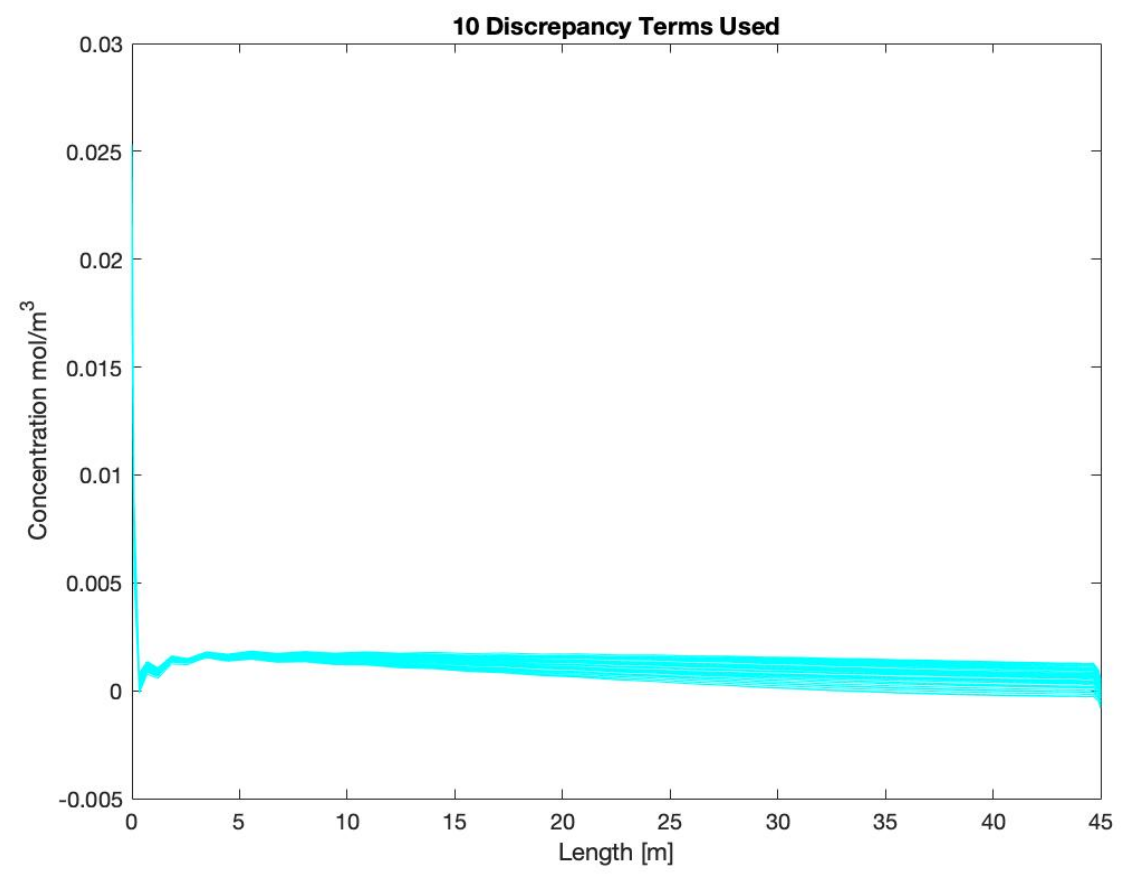

(d) C21-C30 PFR Realizations with 10 Discrepancy Terms Used

Figure 16: PFR ROM Realizations for products: (a) $\mathrm{H}_{2} \mathrm{O}$ (b) C1-C10 (c) C11-C20 (d) C21-C30 
As expected, the uncertainty increases along the length of the reactor. The increase in uncertainty can be attributed to the move from the original calibration point. 


\section{Conclusions and Future Work}

The model developed in this thesis has been proven to work in the reduction of the error produced when eliminating the reactions that take place on catalyst sites. However, it should be noted that the data obtained from Visconti et al. only considers cases of temperature varying by five kelvin. As such, to make a more robust model considering temperature as a parameter and/or decoupling Gibbs free energy into entropy and enthalpy to increase accuracy.

The model reduction was done empirically, and through prior knowledge of the chemistry that occurs when a given catalyst is present. Further and more precise reduction can be obtained using sensitivity analysis tools such as the Morris Screening/ Morris Method (Campolongo, Saltelli, \& Cariboni, 2011).

Furthermore, other techniques can be used to reduce the parameter search process. A Density Functional Theory model could be implemented, the results of which could then be used within a Microkinetic model and thus shorter your parameter space. This would be an interesting and more complicated process, since as mentioned earlier the complete kinetics of the FischerTropsch synthesis are still debated within literature.

Additionally, the current model calibration was performed using lab-scale data. The next step would be to use industrial-scale data to perform calibrations. Unfortunately, most industrial scale Fischer-Tropsch plants are located overseas with the most popular being operated by Sasol and PetroSA both located in South Africa. Obtaining industrial-scale data, just as lab-scale data, will be hard to gather.

As it stands now, the set of models developed through the calibration step can be used to build and program an adaptive controller, for real-time machine learning. This is a great tool as 
the calculations can be performed offline and thanks to the reduced complexity of the proposed model, the computational time needed for the controller would decrease. 


\section{Bibliography}

Anderson, R. (1956). Kinetics and Reaction mechanism of the Fischer-Tropsch Synthesis. Catalysis, 257-371.

Azadi, P., Brownbridge, G., Kemp, I., Mosbach, S., \& Dennis, J. (2015). Microkinetic Modeling of the Fischer-Tropsch Synthesis over Cobalt Catalysts. ChemCATChem, 137-143.

Azadi, P., Brownbridge, G., Kemp, I., Mosbach, S., \& Dennis, J. (2015). Microkinetic Modeling of the Fischer-Tropsch Synthesis over Cobalt Catalysts. ChemCatChem, 137-143.

Berlinet, A., \& Thomas-Agnan, C. (2004). Reproducing Kernel Hilbert Spaces in Probability and Statistics. Norwell, MA: Kluwer Academic Publishers.

Botes, F. G. (2007). Proposal of a New Product Characterization Model for the Iron-Based LowTemperature Fischer-Tropsch Synthesis. Energy \& Fuels, 1379-1389.

Brandtner, L. (2018). e-crude: climate-neutral crude oil substitute from co2, water and ecopower. Vienna: Porner Groups.

Bukur, D., Lang, X., Mukesh, D., \& Zimmerman, W. (1990). Binder/support effects on the activity and selectivity of iron catalysts in the Fischer-Tropsch synthesis. Industrial \& Engineering Chemistry Research, 1588-1599.

Campolongo, F., Saltelli, A., \& Cariboni, A. (2011). From screening to quantitative sensitivity analysis. A unified approach. Computer Physics Communications, 978-988.

Carmassi, M., Barbillon, P., Keller, M., Parent, E., \& Chiodetti, M. (n.d.). Bayesian calibration of a numerical code for prediction. arXiv preprint arXiv:1801.01810.

Center for Climate and Energy Solutions. (2019, May). Technology Solutions: Carbon Capture. Retrieved 10 20, 2019

Chaumette, P., Verdon, C., \& Boucot, P. (1995). Influence of the hydrocarbons distribution on the heat produced during Fischer-Tropsch synthesis. Topics in Catalysis, 301-311.

Del Moral, P., Doucet, A., \& Jasra, A. (2011). An adaptive sequential Monte Carlo method for approximate Bayesian computation. Statistic and Computing.

Dry, M. (1990, January). Fischer-Tropsch Synthesis Over Iron Catalysts. Catalysis Letters, 7(14), 241-251.

Fischer, F., \& Tropsch, H. (1930). United States of America Patent No. 1746464.

Flory, P. (1936). Molecular Size Distribution in Linear Condensation Polymers. Journal of the American Chemical Society, 1877-1885.

Fontenelle Jr, A. B., \& Fernandes, F. A. (2011). Comprehensive Polymerization Model for Fischer-Tropsch Synthesis. Chemical Engineering \& Technology, 963-971.

Frellsen, J., \& Bui, T. (2014, February 6). An introduction to Sequential Monte Carlo. Cambridge.

Friedel, R. A., \& Anderson, R. (1950). COMPOSITION OF SYNTHETIC LIQUID FUELS. I. PRODUCT DISTRIBUTION AND ANALYSIS OF C5-C8 PARAFFIN ISOMERS FROM COBALT CATALYST. Journal of the American Chemical Society, 1212-1215.

Froment, G., Bischoff, K., \& De Wild, J. (1999). Chemical Reactor Analysis and Design. New York: Wiley.

Gu, C. (2012, June 21). Smoothing Spline ANOVA Models. New York.

Guettel, R., \& Turek, T. (2009). Comparison of different reactor types for low temperature Fischer-Tropsch synthesis: A simulation study. Chemical Engineering Science, 64, 955964.

Hans-Wilhelm Schiffer. (2016). World Energy Resources. Worlwide: World Energy Council. 
Higdon, D., Kennedy, M., Cavendish, J., Cafeo, J., \& Ryne, R. (2004). Combining field data and computer simulations for calibration and prediction. SIAM Journal on Scientific Computing, 448-466.

Jess, A., \& Kern, C. (2009). Modeling of Multi-Tubular Reactors for Fischer-Tropsch Synthesis. Chemical Engineering \& Technology, 1164-1175.

Kennedy, M., \& O'Hagan, A. (2001). Bayesian Calibration of Computer Models. Journal of the Royal Statistical Society, 425-464.

Liu, J. (2001). Monte Carlo Strategies in Scientific Computing. New York: Springer.

Lualdi, M., Logdberg, S., Regali, F., \& Boutennet, M. (2011). Investigation of mixtures of a Cobased catalyst and a Cu-based catalyst for the fischer-tropsch synthesis with Bio-Syngas: The importance of in- digenous water. Topics in Catalysis, 977-985.

Mebane, D., Storlie, C., Mahapatra, P., \& Sham Bhat, K. (2014). Upscaling Uncertainty with Dynamic Discrepancy for a Multi-scale Carbon Capture System. Journal of the American Statistical Association.

Miller, A. E. (1945). The Story of The Technical Oil Mission. American Petroleum Institue. Chicago, IL.

Pratt, J. (2012). A Fischer-Tropsch Synthesis Reactor Model Framework for Liquid Biofuels Production. Livermore: Sandia National Laboratories.

Rafiee, A., \& Hillestad, M. (2011). Staging of the Fischer-Tropsch reactor with an iron based catalyst. Computers \& Chemical Engineering, 75-83.

Reich, B., Storlie, C., \& Bondell, H. (2009). Variable selection in bayesian smoothing spline anova models: Application to deterministic computer codes. Technometrics, 110-120.

Reich, B., Storlie, C., \& Bondell, H. (2009). Variable selection in Bayesian smoothing spline ANOVA models: Application to deterministic computer codes. Technometrics, 110-120.

Rice, S., \& Mann, D. (2007). Autothermal Reforming of Natural Gas to Synthesis Gas. Albuquerque: Sandia National Laboratories.

Sarup, B., \& Wojciechowski, B. W. (1989). Studies of the fischer-tropsch synthesis on a cobalt catalyst II. Kinetics of carbon monoxide conversion to methane and to higher hydrocarbons. The Canadian Journal of Chemical Engineering, 62-74.

Schouten, J., Hensen, E., \& van Santen, R. (2015). Quantum Chemical and Microkinetic Modeling of the Fischer-Tropsch Reaction.

Schultz, G. (1935). Highly polymerized compounds CXXXIV. Distribution of molecular weight in highly polymerized mixtures and the determination of the average molecular weight. Journal of Research in Physical Chemistry \& Chemical Physics, 379-385.

Shafer, W., Gnanamani, M., Graham, U., \& Yang, J. (2019). Fischer-Tropsch: Product Selectivity-The Fingerprint of Synthetic Fuels. Catalysts, 259.

Storlie, C., Lane, W., Ryan, E., Gattiker, J., \& Higdon, D. (2015). Calibration of Computational Models with Categorical Parameters and Correlated Outputs via Bayesian Smoothing Spline ANOVA. Journal of the American Statistical Association, 68-82.

Storlie, C., Swiler, L., Helton, J., \& Sallaberry, C. (2009). Implementation and evaluation of nonparametric regression procedures for sensitivity analysis of computationally demanding models. Reliability Engineering and System Safety, 1735-1763.

Tian, L., Huo, C.-F., Cao, D.-B., Yang, Y., Xu, J., Wu, B.-S., . . Li, Y.-W. (2010). Effects of reaction conditions on iron-catalyzed Fischer-Tropsch synthesis: A kinetic Monte Carlo study. Journal of Molecular Structure: THEOCHEM, 30-35.

U.S. Energy Information Administration. (2017, September 14). International Energy Outlook 2017. pp. 9-14. 
Van Der Laan, G. P., \& Beenackers, A. A. (1999). Hydrocarbon Selectivity Model for the Gas-Solid Fischer-Tropsch Synthesis on Precipitated Iron Catalysts. Industrial \& Engineering Chemistry Research, 1277-1290.

Visconti, C. G., Tronconi, E., Lietti, L., Zennaro, R., \& Forzatti, P. (2006). Development of a Complete Kinetic Model for the Fischer-Tropsch Synthesis over Co/A12O3 Catalysts. Synthesis Gas Chemistry (pp. 255-262). Dresden: DGMK/SCI.

Wagner, N., Coertzen, M., \& Matjie, R. (2008). Applied Coal Petrology: The Role of Petrology in Coal Utilization.

Wang, Y.-N., Xu, Y.-Y., Li, Y.-W., Zhao, Y.-L., \& Zhang, B.-J. (2003). Heterogeneous modeling for fixed-bed Fischer-Tropsch synthesis: Reactor model and its applications. Chemical Engineering Science, 58(3), 867.

Zafar, S. (2019). Overview of Biomass Pyrolysis. BioEnergy Consult.

Zhang, R., Chang, J., Xu, Y., Cao, L., Li, Y., \& Zhou, J. (2009). Kinetic Model of Product Distribution over Fe Catalyst for Fischer-Tropsch Synthesis. Energy \& Fuels, 4740-4747.

Zhou, L. (2016). Advanced Fundamental Modeling of the Kinetics of Fischer-Tropsch Synthesis. American Institute of Chemical Engineers, 1668-1682.

Zhou, L.-P., Hao, X., Gao, J.-H., Yang, Y., Wu, B.-S., Xu, J., . . . Li, Y.-W. (2010). Studies and Discriminations of the Kinetic Models for the Iron-Based Fischer-Tropsch Catalytic Reaction in a Recycle Slurry Reactor. Energy \& Fuels, 52-59.

Zimmerman, W., \& Bukur, D. (1990). Reaction kinetics over iron catalysts used for the fischertropsch synthesis. The Canadian Journal of Chemical Engineering, 292-301. 


\section{Appendix}

\begin{tabular}{|c|c|c|c|c|c|c|c|c|}
\hline \multicolumn{9}{|c|}{ Non-Discrepancy Case } \\
\hline Parameter & $\begin{array}{c}\text { Mean } \\
\pm \\
\text { Conf. }\end{array}$ & Std. & Parameter & $\begin{array}{c}\text { Mean } \\
\pm \\
\text { Conf. }\end{array}$ & Std. & Parameter & $\begin{array}{c}\text { Mean } \pm \\
\text { Conf. }\end{array}$ & Std. \\
\hline $\begin{array}{c}\Delta \boldsymbol{G}_{1} \\
(\mathrm{~kJ} / \mathrm{mol})\end{array}$ & $\begin{array}{l}-104.55 \\
\pm 7.13\end{array}$ & 8.74 & $\begin{array}{c}E_{a_{1}} \\
(\mathrm{~kJ} / \mathrm{mol})\end{array}$ & $\begin{array}{r}254.52 \\
\pm 5.43\end{array}$ & 8.49 & $\overline{A_{1}}$ & $\begin{array}{r}2803.29 \\
\pm 41.37\end{array}$ & 612.76 \\
\hline $\begin{array}{c}\Delta \boldsymbol{G}_{2} \\
(\mathrm{~kJ} / \mathrm{mol})\end{array}$ & $\begin{array}{l}-21.14 \\
\pm 2.03\end{array}$ & 4.38 & $\begin{array}{c}E_{a_{2}} \\
(\mathrm{~kJ} / \mathrm{mol})\end{array}$ & $\begin{array}{l}43.44 \\
\pm 2.42\end{array}$ & 5.39 & $\overline{A_{2}}$ & $\begin{array}{r}2114.88 \\
\pm 227.7\end{array}$ & 328.17 \\
\hline $\begin{array}{c}\Delta \boldsymbol{G}_{3} \\
(\mathrm{~kJ} / \mathrm{mol})\end{array}$ & $\begin{array}{l}-29.71 \\
\pm 3.98\end{array}$ & 4.62 & $\begin{array}{c}E_{a_{3}} \\
(\mathrm{~kJ} / \mathrm{mol})\end{array}$ & $\begin{array}{r}143.34 \\
\pm 8.34\end{array}$ & 9.35 & $A_{3}$ & $\begin{array}{l}1502.61 \\
\pm 41.77\end{array}$ & 220.25 \\
\hline $\begin{array}{c}\Delta \boldsymbol{G}_{4} \\
(\mathrm{~kJ} / \mathrm{mol})\end{array}$ & $\begin{array}{l}-80.43 \\
\pm 2.11\end{array}$ & 4.36 & $\begin{array}{c}E_{a_{4}} \\
(\mathrm{~kJ} / \mathrm{mol})\end{array}$ & $\begin{array}{r}101.25 \\
\pm 2.52\end{array}$ & 3.9 & $A_{4}$ & $\begin{array}{r}5736.08 \\
\pm 116.15\end{array}$ & 239.62 \\
\hline $\begin{array}{c}\Delta \boldsymbol{G}_{5} \\
(\mathrm{~kJ} / \mathrm{mol})\end{array}$ & $\begin{array}{l}-33.65 \\
\pm 2.21\end{array}$ & 3.02 & $\begin{array}{c}E_{a_{5}} \\
(\mathrm{~kJ} / \mathrm{mol})\end{array}$ & $\begin{array}{r}43.33 \\
\pm 5.81\end{array}$ & 8.95 & $A_{5}$ & $\begin{array}{r}1023.05 \\
\pm 166.83\end{array}$ & 307.83 \\
\hline $\begin{array}{c}\Delta \boldsymbol{G}_{\mathbf{6}} \\
(\mathrm{kJ} / \mathrm{mol})\end{array}$ & $\begin{array}{l}-87.85 \\
\pm 7.98\end{array}$ & 8.21 & $\begin{array}{c}E_{a_{6}} \\
(\mathrm{~kJ} / \mathrm{mol})\end{array}$ & $\begin{array}{l}40.02 \\
\pm 2.52\end{array}$ & 3.6 & $A_{6}$ & $\begin{array}{r}2477.05 \\
\pm 162.83\end{array}$ & 378.74 \\
\hline $\begin{array}{c}\Delta \boldsymbol{G}_{7} \\
(\mathrm{~kJ} / \mathrm{mol})\end{array}$ & $\begin{array}{l}121.2 \\
\pm 11.38\end{array}$ & 13.03 & $\begin{array}{c}E_{a_{7}} \\
(\mathrm{~kJ} / \mathrm{mol})\end{array}$ & $\begin{array}{l}56.54 \\
\pm 1.37\end{array}$ & 3.85 & $A_{7}$ & $\begin{array}{l}2846.19 \\
\pm 45.95\end{array}$ & 625.97 \\
\hline $\begin{array}{c}\Delta \boldsymbol{G}_{\mathbf{8}} \\
(\mathrm{kJ} / \mathrm{mol})\end{array}$ & $\begin{array}{l}-29.73 \\
\pm 4.83\end{array}$ & 5.45 & $\begin{array}{c}E_{a_{8}} \\
(\mathrm{~kJ} / \mathrm{mol})\end{array}$ & $\begin{array}{l}76.25 \\
\pm 2.11\end{array}$ & 3.29 & $A_{8}$ & $\begin{array}{r}8424.59 \\
\pm 373.22\end{array}$ & 650.13 \\
\hline
\end{tabular}




\begin{tabular}{|c|c|c|c|c|c|c|c|c|}
\hline $\begin{array}{c}\Delta \boldsymbol{G}_{\mathbf{9}} \\
(\mathrm{kJ} / \mathrm{mol})\end{array}$ & $\begin{array}{l}-25.9 \\
\pm 5.33\end{array}$ & 8.67 & $\begin{array}{c}E_{a_{9}} \\
(\mathrm{~kJ} / \mathrm{mol})\end{array}$ & $\begin{array}{l}107.07 \\
\pm 4.32\end{array}$ & 7.4 & $A_{9}$ & $\begin{array}{r}8652.83 \\
+363.96\end{array}$ & 553.7 \\
\hline $\begin{array}{c}\Delta \boldsymbol{G}_{10} \\
(\mathrm{~kJ} / \mathrm{mol})\end{array}$ & $\begin{array}{l}168.3 \\
\pm 3.96\end{array}$ & 5.39 & $\begin{array}{c}E_{a_{10}} \\
(\mathrm{~kJ} / \mathrm{mol})\end{array}$ & $\begin{array}{l}86.18 \\
\pm 5.18\end{array}$ & 7.71 & $A_{10}$ & $\begin{array}{l}1019.04 \\
\pm 46.27\end{array}$ & 281.11 \\
\hline $\begin{array}{c}\Delta \boldsymbol{G}_{11} \\
(\mathrm{~kJ} / \mathrm{mol})\end{array}$ & $\begin{array}{l}49.25 \\
\pm 1.26\end{array}$ & 5.31 & $\begin{array}{c}E_{a_{11}} \\
(\mathrm{~kJ} / \mathrm{mol})\end{array}$ & $\begin{array}{l}147.67 \\
\pm 6.85\end{array}$ & 8.33 & $A_{11}$ & $\begin{array}{r}1961.33 \\
\pm 233.07\end{array}$ & 666.93 \\
\hline $\begin{array}{c}\Delta \boldsymbol{G}_{12} \\
(\mathrm{~kJ} / \mathrm{mol})\end{array}$ & $\begin{array}{l}240.75 \\
\pm 19.40\end{array}$ & 22.37 & $\begin{array}{c}E_{a_{12}} \\
(\mathrm{~kJ} / \mathrm{mol})\end{array}$ & $\begin{array}{l}113.11 \\
\pm 2.23\end{array}$ & 8.93 & $A_{12}$ & $\begin{array}{r}2383.15 \\
\pm 137.63\end{array}$ & 420.58 \\
\hline $\begin{array}{c}\Delta \boldsymbol{G}_{13} \\
(\mathrm{~kJ} / \mathrm{mol})\end{array}$ & $\begin{array}{l}136.19 \\
\pm 1.89\end{array}$ & 2.87 & $\begin{array}{c}E_{a_{13}} \\
(\mathrm{~kJ} / \mathrm{mol})\end{array}$ & $\begin{array}{r}258.40 \\
\pm 3.39\end{array}$ & 5.67 & $A_{13}$ & $\begin{array}{r}2459.46 \\
\pm 397.03\end{array}$ & 566.15 \\
\hline $\begin{array}{c}\Delta \boldsymbol{G}_{\mathbf{1 4}} \\
(\mathrm{kJ} / \mathrm{mol})\end{array}$ & $\begin{array}{l}162.09 \\
\pm 9.67\end{array}$ & 12.50 & $\begin{array}{c}E_{a_{14}} \\
(\mathrm{~kJ} / \mathrm{mol})\end{array}$ & $\begin{array}{l}61.65 \\
\pm 2.37\end{array}$ & 6.29 & $A_{14}$ & $\begin{array}{r}5345.73 \\
\pm 145.79\end{array}$ & 971.84 \\
\hline $\begin{array}{c}\Delta \boldsymbol{G}_{\mathbf{1 5}} \\
(\mathrm{kJ} / \mathrm{mol})\end{array}$ & $\begin{array}{l}47.83 \\
\pm 2.28\end{array}$ & 2.90 & $\begin{array}{c}E_{a_{15}} \\
(\mathrm{~kJ} / \mathrm{mol})\end{array}$ & $\begin{array}{l}208.03 \\
\pm 1.43\end{array}$ & 4.01 & $A_{15}$ & $\begin{array}{r}2775.50 \\
+344.65\end{array}$ & 672.25 \\
\hline $\begin{array}{c}\Delta \boldsymbol{G}_{16} \\
(\mathrm{~kJ} / \mathrm{mol})\end{array}$ & $\begin{array}{l}13.65 \\
\pm 0.68\end{array}$ & 3.76 & $\begin{array}{c}E_{a_{16}} \\
(\mathrm{~kJ} / \mathrm{mol})\end{array}$ & $\begin{array}{l}100.23 \\
\pm 6.86\end{array}$ & 8.74 & $A_{16}$ & $\begin{array}{r}1713.34 \\
\pm 56.66\end{array}$ & 320.7 \\
\hline $\begin{array}{c}\Delta \boldsymbol{G}_{17} \\
(\mathrm{~kJ} / \mathrm{mol})\end{array}$ & $\begin{array}{l}247.19 \\
\pm 15.9\end{array}$ & 17.42 & $\begin{array}{c}E_{a_{17}} \\
(\mathrm{~kJ} / \mathrm{mol})\end{array}$ & $\begin{array}{l}15.63 \\
\pm 2.28\end{array}$ & 4.39 & $A_{17}$ & $\begin{array}{r}2208.57 \\
\pm 149.55\end{array}$ & 401.64 \\
\hline $\begin{array}{c}\Delta \boldsymbol{G}_{18} \\
(\mathrm{~kJ} / \mathrm{mol})\end{array}$ & $\begin{array}{l}27.21 \\
\pm 3.12\end{array}$ & 6.76 & $\begin{array}{c}E_{a_{18}} \\
(\mathrm{~kJ} / \mathrm{mol})\end{array}$ & $\begin{array}{l}74.30 \\
\pm 4.01\end{array}$ & 10.09 & $A_{18}$ & $\begin{array}{r}1585.64 \\
\pm 87.4\end{array}$ & 292.11 \\
\hline $\begin{array}{c}\Delta \boldsymbol{G}_{19} \\
(\mathrm{~kJ} / \mathrm{mol})\end{array}$ & $\begin{array}{l}36.51 \\
\pm 1.42\end{array}$ & 3.05 & $\begin{array}{c}E_{a_{19}} \\
(\mathrm{~kJ} / \mathrm{mol})\end{array}$ & $\begin{array}{l}154.78 \\
\pm 5.49\end{array}$ & 10.92 & $A_{19}$ & $\begin{array}{r}7661.27 \\
\pm 345.21\end{array}$ & 790.25 \\
\hline
\end{tabular}




\begin{tabular}{|c|c|c|c|c|c|c|c|c|}
\hline $\begin{array}{c}\Delta \boldsymbol{G}_{20} \\
(\mathrm{~kJ} / \mathrm{mol})\end{array}$ & $\begin{array}{l}127.74 \\
\pm 7.51\end{array}$ & 15.56 & $\begin{array}{c}E_{a_{20}} \\
(\mathrm{~kJ} / \mathrm{mol})\end{array}$ & $\begin{array}{r}106.68 \\
\pm 3.17\end{array}$ & 7.22 & $A_{20}$ & $\begin{array}{r}3215.98 \\
\pm 185.62\end{array}$ & 474.86 \\
\hline $\begin{array}{c}\Delta \boldsymbol{G}_{21} \\
(\mathrm{~kJ} / \mathrm{mol})\end{array}$ & $\begin{array}{r}318.94 \\
\pm 9.82\end{array}$ & 16.70 & $\begin{array}{c}E_{a_{21}} \\
(\mathrm{~kJ} / \mathrm{mol})\end{array}$ & $\begin{array}{r}127.83 \\
\pm 3.38\end{array}$ & 14.69 & $\overline{A_{21}}$ & $\begin{array}{r}1684.57 \\
\pm 249.4\end{array}$ & 321.16 \\
\hline $\begin{array}{c}\Delta \boldsymbol{G}_{22} \\
(\mathrm{~kJ} / \mathrm{mol})\end{array}$ & $\begin{array}{r}134.36 \\
\pm 0.66\end{array}$ & 12.71 & $\begin{array}{c}E_{a_{22}} \\
(\mathrm{~kJ} / \mathrm{mol})\end{array}$ & $\begin{array}{l}168.73 \\
\pm 10.25\end{array}$ & 12.34 & $A_{22}$ & $\begin{array}{r}3381.92 \\
\pm 232.45\end{array}$ & 388.22 \\
\hline $\begin{array}{c}\Delta \boldsymbol{G}_{23} \\
(\mathrm{~kJ} / \mathrm{mol})\end{array}$ & $\begin{array}{l}251.78 \\
\pm 11.18\end{array}$ & 17.31 & $\begin{array}{c}E_{a_{23}} \\
(\mathrm{~kJ} / \mathrm{mol})\end{array}$ & $\begin{array}{l}74.01 \\
\pm 1.98\end{array}$ & 12.17 & $\overline{A_{23}}$ & $\begin{array}{r}2993.52 \\
\pm 293.97\end{array}$ & 459.14 \\
\hline $\begin{array}{c}\Delta \boldsymbol{G}_{24} \\
(\mathrm{~kJ} / \mathrm{mol})\end{array}$ & $\begin{array}{l}244.2 \\
\pm 9.98\end{array}$ & 18.89 & $\begin{array}{c}E_{a_{24}} \\
(\mathrm{~kJ} / \mathrm{mol})\end{array}$ & $\begin{array}{r}162.52 \\
\pm 1.83\end{array}$ & 13.94 & $\overline{A_{24}}$ & $\begin{array}{c}10896.1 \\
3 \pm 373.1 \\
1\end{array}$ & 870.50 \\
\hline $\begin{array}{c}\Delta \boldsymbol{G}_{25} \\
(\mathrm{~kJ} / \mathrm{mol})\end{array}$ & $\begin{array}{r}171.13 \\
\pm 4.48\end{array}$ & 12.50 & $\begin{array}{c}E_{a_{25}} \\
(\mathrm{~kJ} / \mathrm{mol})\end{array}$ & $\begin{array}{l}58.16 \\
\pm 3.25\end{array}$ & 8.69 & $\overline{A_{25}}$ & $\begin{array}{l}1642.73 \\
\pm 157.52\end{array}$ & 527.62 \\
\hline $\begin{array}{c}\Delta \boldsymbol{G}_{26} \\
(\mathrm{~kJ} / \mathrm{mol})\end{array}$ & $\begin{array}{r}168.04 \\
\pm 1.13\end{array}$ & 14.80 & $\begin{array}{c}E_{a_{26}} \\
(\mathrm{~kJ} / \mathrm{mol})\end{array}$ & $\begin{array}{l}13.86 \\
\pm 0.66\end{array}$ & 1.37 & $A_{26}$ & $\begin{array}{r}3488.50 \\
\pm 221.45\end{array}$ & 567.58 \\
\hline $\begin{array}{c}\Delta \boldsymbol{G}_{27} \\
(\mathrm{~kJ} / \mathrm{mol})\end{array}$ & $\begin{array}{r}287.04 \\
\pm 2.13\end{array}$ & 5.14 & $\begin{array}{c}E_{a_{27}} \\
(\mathrm{~kJ} / \mathrm{mol})\end{array}$ & $\begin{array}{r}152.31 \\
\pm 9.51\end{array}$ & 16.52 & $A_{27}$ & $\begin{array}{c}3968.8 \pm \\
301.5\end{array}$ & 479.17 \\
\hline $\begin{array}{c}\Delta \boldsymbol{G}_{\mathbf{2 8}} \\
(\mathrm{kJ} / \mathrm{mol})\end{array}$ & $\begin{array}{r}155.91 \\
\pm 7.40\end{array}$ & 28.44 & $\begin{array}{c}E_{a_{28}} \\
(\mathrm{~kJ} / \mathrm{mol})\end{array}$ & $\begin{array}{l}94.47 \\
\pm 5.58\end{array}$ & 17.10 & $A_{28}$ & $\begin{array}{r}4288.43 \\
\pm 287.01\end{array}$ & 400.81 \\
\hline $\begin{array}{c}\Delta \boldsymbol{G}_{29} \\
(\mathrm{~kJ} / \mathrm{mol})\end{array}$ & $\begin{array}{r}48.48 \\
\pm 1.93\end{array}$ & 4.23 & $\begin{array}{c}E_{a_{29}} \\
(\mathrm{~kJ} / \mathrm{mol})\end{array}$ & $\begin{array}{r}15.60 \\
\pm 3.7\end{array}$ & 6.38 & $\overline{A_{29}}$ & $\begin{array}{r}5345.88 \\
\pm 461.57\end{array}$ & 583.62 \\
\hline
\end{tabular}




\begin{tabular}{|c|c|c|c|c|c|c|c|c|}
\hline $\begin{array}{c}\Delta \boldsymbol{G}_{\mathbf{3 0}} \\
(\mathrm{kJ} / \mathrm{mol})\end{array}$ & $\begin{array}{l}142.5 \\
\pm 7.89\end{array}$ & 9.39 & $\begin{array}{c}E_{a_{30}} \\
(\mathrm{~kJ} / \mathrm{mol})\end{array}$ & $\begin{array}{r}124.98 \\
\pm 1.77\end{array}$ & 2.26 & $A_{30}$ & $\begin{array}{c}6420.9 \pm \\
283.79\end{array}$ & 634.22 \\
\hline $\begin{array}{c}\Delta \boldsymbol{G}_{31} \\
(\mathrm{~kJ} / \mathrm{mol})\end{array}$ & $\begin{array}{r}224.38 \\
\pm 1.56\end{array}$ & 1.79 & $\begin{array}{c}E_{a_{31}} \\
(\mathrm{~kJ} / \mathrm{mol})\end{array}$ & $\begin{array}{l}51.51 \\
\pm 3.03\end{array}$ & 6.70 & $A_{31}$ & $\begin{array}{r}4246.71 \\
\pm 212.41\end{array}$ & 508.9 \\
\hline $\begin{array}{c}\Delta \boldsymbol{G}_{32} \\
(\mathrm{~kJ} / \mathrm{mol})\end{array}$ & $\begin{array}{l}34.01 \\
\pm 7.44\end{array}$ & 5.90 & $\begin{array}{c}E_{a_{32}} \\
(\mathrm{~kJ} / \mathrm{mol})\end{array}$ & $\begin{array}{r}252.45 \\
\pm 2.81\end{array}$ & 5.75 & $\overline{A_{32}}$ & $\begin{array}{r}3439.94 \\
\pm 241.61\end{array}$ & 357.78 \\
\hline $\begin{array}{c}\Delta \boldsymbol{G}_{33} \\
(\mathrm{~kJ} / \mathrm{mol})\end{array}$ & $\begin{array}{l}50.93 \\
\pm 3.46\end{array}$ & 6.50 & $\begin{array}{c}E_{a_{33}} \\
(\mathrm{~kJ} / \mathrm{mol})\end{array}$ & $\begin{array}{l}59.76 \\
\pm 2.82\end{array}$ & 6.35 & $A_{33}$ & $\begin{array}{l}3743.86 \\
\pm 166.1\end{array}$ & 501.39 \\
\hline $\begin{array}{c}\Delta \boldsymbol{G}_{34} \\
(\mathrm{~kJ} / \mathrm{mol})\end{array}$ & $\begin{array}{r}17.94 \\
\pm 1.09\end{array}$ & 5.03 & $\begin{array}{c}E_{a_{34}} \\
(\mathrm{~kJ} / \mathrm{mol})\end{array}$ & $\begin{array}{l}110.2 \\
\pm 3.35\end{array}$ & 5.47 & $A_{34}$ & $\begin{array}{r}1935.65 \\
\pm 68.09\end{array}$ & 225.68 \\
\hline $\begin{array}{c}\Delta \boldsymbol{G}_{35} \\
(\mathrm{~kJ} / \mathrm{mol})\end{array}$ & $\begin{array}{l}150.2 \\
\pm 5.36\end{array}$ & 6.88 & $\begin{array}{c}E_{a_{35}} \\
(\mathrm{~kJ} / \mathrm{mol})\end{array}$ & $\begin{array}{l}112.31 \\
\pm 13.22\end{array}$ & 5.79 & $A_{35}$ & $\begin{array}{l}1795.21 \\
\pm 78.17\end{array}$ & 122.34 \\
\hline $\begin{array}{c}\Delta \boldsymbol{G}_{36} \\
(\mathrm{~kJ} / \mathrm{mol})\end{array}$ & $\begin{array}{l}132.2 \\
\pm 1.23\end{array}$ & 11.43 & $\begin{array}{c}E_{a_{36}} \\
(\mathrm{~kJ} / \mathrm{mol})\end{array}$ & $\begin{array}{r}106.45 \\
\pm 10.92\end{array}$ & 15.65 & $A_{36}$ & $\begin{array}{c}4524.1 \pm \\
175.44\end{array}$ & 347.69 \\
\hline $\begin{array}{c}\Delta G_{37} \\
(\mathrm{~kJ} / \mathrm{mol})\end{array}$ & $\begin{array}{l}58.1 \\
\pm 6.06\end{array}$ & 8.18 & $\begin{array}{c}E_{a_{37}} \\
(\mathrm{~kJ} / \mathrm{mol})\end{array}$ & $\begin{array}{r}133.24 \\
\pm 6.10\end{array}$ & 7.35 & $A_{37}$ & $\begin{array}{c}921.30 \pm \\
21.67\end{array}$ & 96.71 \\
\hline $\begin{array}{c}\Delta \boldsymbol{G}_{\mathbf{3 8}} \\
(\mathrm{kJ} / \mathrm{mol})\end{array}$ & $\begin{array}{r}244.58 \\
\pm 12.1\end{array}$ & 13.97 & $\begin{array}{c}E_{a_{38}} \\
(\mathrm{~kJ} / \mathrm{mol})\end{array}$ & $\begin{array}{l}83.2 \\
\pm 3.65\end{array}$ & 7.82 & $A_{38}$ & $\begin{array}{c}3869.3 \pm \\
262.28\end{array}$ & 135.74 \\
\hline $\begin{array}{c}\Delta \boldsymbol{G}_{39} \\
(\mathrm{~kJ} / \mathrm{mol})\end{array}$ & $\begin{array}{l}70.83 \\
\pm 6.30\end{array}$ & 7.74 & $\begin{array}{c}E_{a_{39}} \\
(\mathrm{~kJ} / \mathrm{mol})\end{array}$ & $\begin{array}{r}112.31 \\
\pm 3.52\end{array}$ & 10.57 & $\overline{A_{39}}$ & $\begin{array}{r}4619.59 \\
\pm 416.82\end{array}$ & 649.73 \\
\hline $\begin{array}{c}\Delta \boldsymbol{G}_{40} \\
(\mathrm{~kJ} / \mathrm{mol})\end{array}$ & $\begin{array}{l}326.03 \\
\pm 18.35\end{array}$ & 20.08 & $\begin{array}{c}E_{a_{40}} \\
(\mathrm{~kJ} / \mathrm{mol})\end{array}$ & $\begin{array}{l}74.45 \\
\pm 2.18\end{array}$ & 3.98 & $A_{40}$ & $\begin{array}{r}4110.46 \\
\pm 269.45\end{array}$ & 781.70 \\
\hline
\end{tabular}




\begin{tabular}{|c|c|c|c|c|c|c|c|c|}
\hline $\begin{array}{c}\Delta \boldsymbol{G}_{\mathbf{4 1}} \\
(\mathrm{kJ} / \mathrm{mol})\end{array}$ & $\begin{array}{l}238.09 \\
\pm 18.32\end{array}$ & 19.8 & $\begin{array}{c}E_{a_{41}} \\
(\mathrm{~kJ} / \mathrm{mol})\end{array}$ & $\begin{array}{l}124.82 \\
\pm 4.06\end{array}$ & 5.82 & $A_{41}$ & $\begin{array}{r}8087.56 \\
\pm 381.27\end{array}$ & 836.1 \\
\hline $\begin{array}{c}\Delta \boldsymbol{G}_{42} \\
(\mathrm{~kJ} / \mathrm{mol})\end{array}$ & $\begin{array}{l}238.84 \\
\pm 8.49\end{array}$ & 11.46 & $\begin{array}{c}E_{a_{42}} \\
(\mathrm{~kJ} / \mathrm{mol})\end{array}$ & $\begin{array}{l}150.13 \\
\pm 2.39\end{array}$ & 4.92 & $A_{42}$ & $\begin{array}{r}4711.63 \\
\pm 247.04\end{array}$ & 397.58 \\
\hline $\begin{array}{c}\Delta \boldsymbol{G}_{\mathbf{4 3}} \\
(\mathrm{kJ} / \mathrm{mol})\end{array}$ & $\begin{array}{l}66.26 \\
\pm 1.97\end{array}$ & 2.98 & $\begin{array}{c}E_{a_{43}} \\
(\mathrm{~kJ} / \mathrm{mol})\end{array}$ & $\begin{array}{r}227.30 \\
\pm 2.31\end{array}$ & 13.07 & $A_{43}$ & $\begin{array}{r}3146.53 \\
\pm 102.64\end{array}$ & 269.42 \\
\hline $\begin{array}{c}\Delta \boldsymbol{G}_{\mathbf{4 4}} \\
(\mathrm{kJ} / \mathrm{mol})\end{array}$ & $\begin{array}{l}100.68 \\
\pm 2.21\end{array}$ & 4.24 & $\begin{array}{c}E_{a_{44}} \\
(\mathrm{~kJ} / \mathrm{mol})\end{array}$ & $\begin{array}{l}23.71 \\
\pm 1.38\end{array}$ & 2.73 & $A_{44}$ & $\begin{array}{r}1717.73 \\
\pm 224.16\end{array}$ & 388.99 \\
\hline $\begin{array}{c}\Delta \boldsymbol{G}_{\mathbf{4 5}} \\
(\mathrm{kJ} / \mathrm{mol})\end{array}$ & $\begin{array}{l}192.1 \\
\pm 1.35\end{array}$ & 6.73 & $\begin{array}{c}E_{a_{45}} \\
(\mathrm{~kJ} / \mathrm{mol})\end{array}$ & $\begin{array}{l}16.04 \\
\pm 1.02\end{array}$ & 5.54 & $A_{45}$ & $\begin{array}{r}6498.16 \\
\pm 417.49\end{array}$ & 675.0 \\
\hline $\begin{array}{c}\Delta \boldsymbol{G}_{46} \\
(\mathrm{~kJ} / \mathrm{mol})\end{array}$ & $\begin{array}{l}54.52 \\
\pm 1.39\end{array}$ & 10.98 & $\begin{array}{c}E_{a_{46}} \\
(\mathrm{~kJ} / \mathrm{mol})\end{array}$ & $\begin{array}{l}114.34 \\
\pm 3.31\end{array}$ & 10.86 & $A_{46}$ & $\begin{array}{r}1599.39 \\
\pm 147.05\end{array}$ & 699.85 \\
\hline $\begin{array}{c}\Delta \boldsymbol{G}_{47} \\
(\mathrm{~kJ} / \mathrm{mol})\end{array}$ & $\begin{array}{l}265.94 \\
\pm 7.5\end{array}$ & 24.89 & $\begin{array}{c}E_{a_{47}} \\
(\mathrm{~kJ} / \mathrm{mol})\end{array}$ & $\begin{array}{l}121.96 \\
\pm 5.23\end{array}$ & 11.30 & $A_{47}$ & $\begin{array}{r}2401.99 \\
\pm 137.54\end{array}$ & 439.33 \\
\hline $\begin{array}{c}\Delta \boldsymbol{G}_{\mathbf{4 8}} \\
(\mathrm{kJ} / \mathrm{mol})\end{array}$ & $\begin{array}{l}157.36 \\
\pm 4.68\end{array}$ & 19.14 & $\begin{array}{c}E_{a_{48}} \\
(\mathrm{~kJ} / \mathrm{mol})\end{array}$ & $\begin{array}{l}162.51 \\
\pm 6.9\end{array}$ & 12.59 & $A_{48}$ & $\begin{array}{r}4975.05 \\
\pm 202.58\end{array}$ & 629.70 \\
\hline $\begin{array}{c}\Delta \boldsymbol{G}_{49} \\
(\mathrm{~kJ} / \mathrm{mol})\end{array}$ & $\begin{array}{l}111.14 \\
\pm 9.72\end{array}$ & 17.77 & $\begin{array}{c}E_{a_{49}} \\
(\mathrm{~kJ} / \mathrm{mol})\end{array}$ & $\begin{array}{l}54.85 \\
\pm 1.61\end{array}$ & 15.72 & $\overline{A_{49}}$ & $\begin{array}{l}1767.14 \\
\pm 219.10\end{array}$ & 310.96 \\
\hline $\begin{array}{c}\Delta \boldsymbol{G}_{\mathbf{5 0}} \\
(\mathrm{kJ} / \mathrm{mol})\end{array}$ & $\begin{array}{l}253.56 \\
\pm 3.68\end{array}$ & 5.47 & $\begin{array}{c}E_{a_{50}} \\
(\mathrm{~kJ} / \mathrm{mol})\end{array}$ & $\begin{array}{l}135.84 \\
\pm 4.95\end{array}$ & 14.71 & $A_{50}$ & $\begin{array}{r}4807.80 \\
\pm 234.12\end{array}$ & 561.83 \\
\hline $\begin{array}{c}\Delta \boldsymbol{G}_{\mathbf{5 1}} \\
(\mathrm{kJ} / \mathrm{mol})\end{array}$ & $\begin{array}{l}408.82 \\
\pm 16.57\end{array}$ & 18.66 & $\begin{array}{c}E_{a_{51}} \\
(\mathrm{~kJ} / \mathrm{mol})\end{array}$ & $\begin{array}{l}34.06 \\
\pm 5.69\end{array}$ & 9.89 & $A_{51}$ & $\begin{array}{r}7530.62 \\
\pm 296.88\end{array}$ & 708.16 \\
\hline
\end{tabular}




\begin{tabular}{|c|c|c|c|c|c|c|c|c|}
\hline $\begin{array}{c}\Delta \boldsymbol{G}_{52} \\
(\mathrm{~kJ} / \mathrm{mol})\end{array}$ & $\begin{array}{l}252.24 \\
\pm 3.71\end{array}$ & 10.56 & $\begin{array}{c}E_{a_{52}} \\
(\mathrm{~kJ} / \mathrm{mol})\end{array}$ & $\begin{array}{l}74.15 \\
\pm 2.92\end{array}$ & 9.03 & $A_{52}$ & $\begin{array}{r}6084.17 \\
\pm 211.66\end{array}$ & 343.99 \\
\hline $\begin{array}{c}\Delta \boldsymbol{G}_{\mathbf{5 3}} \\
(\mathrm{kJ} / \mathrm{mol})\end{array}$ & $\begin{array}{l}125.66 \\
\pm 1.33\end{array}$ & 9.92 & $\begin{array}{c}E_{a_{53}} \\
(\mathrm{~kJ} / \mathrm{mol})\end{array}$ & $\begin{array}{l}44.07 \\
\pm 1.35\end{array}$ & 3.95 & $A_{53}$ & $\begin{array}{l}2421.24 \\
\pm 31.93\end{array}$ & 225.99 \\
\hline $\begin{array}{c}\Delta \boldsymbol{G}_{\mathbf{5 4}} \\
(\mathrm{kJ} / \mathrm{mol})\end{array}$ & $\begin{array}{r}269.88 \\
\pm 4.57\end{array}$ & 8.51 & $\begin{array}{c}E_{a_{54}} \\
(\mathrm{~kJ} / \mathrm{mol})\end{array}$ & $\begin{array}{l}23.38 \\
\pm 3.67\end{array}$ & 4.83 & $A_{54}$ & $\begin{array}{r}4640.38 \\
\pm 103.59\end{array}$ & 407.29 \\
\hline $\begin{array}{c}\Delta \boldsymbol{G}_{\mathbf{5 5}} \\
(\mathrm{kJ} / \mathrm{mol})\end{array}$ & $\begin{array}{l}179.25 \\
\pm 8.54\end{array}$ & 14.73 & $\begin{array}{c}E_{a_{55}} \\
(\mathrm{~kJ} / \mathrm{mol})\end{array}$ & $\begin{array}{l}90.07 \\
\pm 3.15\end{array}$ & 13.87 & $A_{55}$ & $\begin{array}{r}6637.93 \\
\pm 375.63\end{array}$ & 500.45 \\
\hline $\begin{array}{c}\Delta \boldsymbol{G}_{56} \\
(\mathrm{~kJ} / \mathrm{mol})\end{array}$ & $\begin{array}{l}376.5 \\
\pm 1.04\end{array}$ & 23.92 & $\begin{array}{c}E_{a_{56}} \\
(\mathrm{~kJ} / \mathrm{mol})\end{array}$ & $\begin{array}{l}61.94 \\
\pm 6.87\end{array}$ & 9.91 & $A_{56}$ & $\begin{array}{r}1554.93 \\
\pm 157.62\end{array}$ & 205.91 \\
\hline
\end{tabular}

Table 2: Statistics of the Posterior distribution for the baseline case

\begin{tabular}{|c|c|c|c|c|c|c|c|c|}
\hline \multicolumn{9}{|c|}{ Discrepancy Case } \\
\hline Parameter & $\begin{array}{c}\text { Mean } \\
\pm \\
\text { Conf. }\end{array}$ & Std. & Parameter & $\begin{array}{c}\text { Mean } \\
\pm \\
\text { Conf. }\end{array}$ & Std. & Parameter & $\begin{array}{l}\text { Mean } \pm \\
\text { Conf. }\end{array}$ & Std. \\
\hline $\begin{array}{c}\Delta \boldsymbol{G}_{1} \\
(\mathrm{~kJ} / \mathrm{mol})\end{array}$ & $\begin{array}{l}-50.45 \\
\pm 7.12\end{array}$ & 3.23 & $\begin{array}{c}E_{a_{1}} \\
(\mathrm{~kJ} / \mathrm{mol})\end{array}$ & $\begin{array}{l}100.52 \\
\pm 8.3\end{array}$ & 7.51 & $A_{1}$ & $\begin{array}{l}4251.29 \\
\pm 34.28\end{array}$ & 508.19 \\
\hline $\begin{array}{c}\Delta G_{2} \\
(\mathrm{~kJ} / \mathrm{mol})\end{array}$ & $\begin{array}{l}-31.86 \\
\pm 3.03\end{array}$ & 2.93 & $\begin{array}{c}E_{a_{2}} \\
(\mathrm{~kJ} / \mathrm{mol})\end{array}$ & $\begin{array}{l}46.58 \\
\pm 3.56\end{array}$ & 6.46 & $A_{2}$ & $\begin{array}{l}2865.7 \\
\pm 123.12\end{array}$ & 204.88 \\
\hline $\begin{array}{c}\Delta G_{3} \\
(\mathrm{~kJ} / \mathrm{mol})\end{array}$ & $\begin{array}{l}-24.29 \\
\pm 5.28\end{array}$ & 1.31 & $\begin{array}{c}E_{a_{3}} \\
(\mathrm{~kJ} / \mathrm{mol})\end{array}$ & $\begin{array}{l}21.34 \\
\pm 6.73\end{array}$ & 7.44 & $A_{3}$ & $\begin{array}{l}1149.61 \\
\pm 64.74\end{array}$ & 165.25 \\
\hline
\end{tabular}




\begin{tabular}{|c|c|c|c|c|c|c|c|c|}
\hline $\begin{array}{c}\Delta \boldsymbol{G}_{4} \\
(\mathrm{~kJ} / \mathrm{mol})\end{array}$ & $\begin{array}{l}-16.57 \\
\pm 1.16\end{array}$ & 2.18 & $\begin{array}{c}E_{a_{4}} \\
(\mathrm{~kJ} / \mathrm{mol})\end{array}$ & $\begin{array}{l}19.25 \\
\pm 0.52\end{array}$ & 1.53 & $A_{4}$ & $\begin{array}{r}4703.69 \\
+128.05\end{array}$ & 630.18 \\
\hline $\begin{array}{c}\Delta \boldsymbol{G}_{5} \\
(\mathrm{~kJ} / \mathrm{mol})\end{array}$ & $\begin{array}{l}-8.65 \\
\pm 0.79\end{array}$ & 2.75 & $\begin{array}{c}E_{a_{5}} \\
(\mathrm{~kJ} / \mathrm{mol})\end{array}$ & $\begin{array}{l}13.67 \\
\pm 3.19\end{array}$ & 5.28 & $A_{5}$ & $\begin{array}{r}1023.05 \\
\pm 166.83\end{array}$ & 251.16 \\
\hline $\begin{array}{c}\Delta \boldsymbol{G}_{\mathbf{6}} \\
(\mathrm{kJ} / \mathrm{mol})\end{array}$ & $\begin{array}{l}0.15 \\
\pm 0.02\end{array}$ & 0.04 & $\begin{array}{c}E_{a_{6}} \\
(\mathrm{~kJ} / \mathrm{mol})\end{array}$ & $\begin{array}{l}75.02 \\
\pm 1.48\end{array}$ & 6.81 & $A_{6}$ & $\begin{array}{l}1565.19 \\
\pm 263.41\end{array}$ & 350.64 \\
\hline $\begin{array}{c}\Delta \boldsymbol{G}_{7} \\
(\mathrm{~kJ} / \mathrm{mol})\end{array}$ & $\begin{array}{l}8.2 \\
\pm 0.84\end{array}$ & 0.97 & $\begin{array}{c}E_{a_{7}} \\
(\mathrm{~kJ} / \mathrm{mol})\end{array}$ & $\begin{array}{l}77.44 \\
\pm 9.63\end{array}$ & 12.78 & $A_{7}$ & $\begin{array}{l}4830.59 \\
\pm 138.26\end{array}$ & 481.53 \\
\hline $\begin{array}{c}\Delta \boldsymbol{G}_{\mathbf{8}} \\
(\mathrm{kJ} / \mathrm{mol})\end{array}$ & $\begin{array}{l}16.27 \\
\pm 5.17\end{array}$ & 1.69 & $\begin{array}{c}E_{a_{8}} \\
(\mathrm{~kJ} / \mathrm{mol})\end{array}$ & $\begin{array}{r}68.75 \\
\pm 7.24\end{array}$ & 8.71 & $A_{8}$ & $\begin{array}{r}5079.83 \\
\pm 66.55\end{array}$ & 395.89 \\
\hline $\begin{array}{c}\Delta \boldsymbol{G}_{\mathbf{9}} \\
(\mathrm{kJ} / \mathrm{mol})\end{array}$ & $\begin{array}{l}25.1 \\
\pm 0.67\end{array}$ & 4.01 & $\begin{array}{c}E_{a_{9}} \\
(\mathrm{~kJ} / \mathrm{mol})\end{array}$ & $\begin{array}{l}94.77 \\
\pm 1.80\end{array}$ & 5.98 & $A_{9}$ & $\begin{array}{l}5681.44 \\
\pm 111.76\end{array}$ & 468.45 \\
\hline $\begin{array}{c}\Delta \boldsymbol{G}_{10} \\
(\mathrm{~kJ} / \mathrm{mol})\end{array}$ & $\begin{array}{l}33.3 \\
\pm 4.61\end{array}$ & 1.06 & $\begin{array}{c}E_{a_{10}} \\
(\mathrm{~kJ} / \mathrm{mol})\end{array}$ & $\begin{array}{r}103.82 \\
\pm 4.65\end{array}$ & 12.98 & $A_{10}$ & $\begin{array}{l}1983.67 \\
\pm 121.93\end{array}$ & 246.34 \\
\hline $\begin{array}{c}\Delta \boldsymbol{G}_{11} \\
(\mathrm{~kJ} / \mathrm{mol})\end{array}$ & $\begin{array}{c}41.25 \pm \\
4.64\end{array}$ & 7.9 & $\begin{array}{c}E_{a_{11}} \\
(\mathrm{~kJ} / \mathrm{mol})\end{array}$ & $\begin{array}{r}116.15 \\
\pm 5.33\end{array}$ & 18.65 & $\overline{A_{11}}$ & $\begin{array}{l}2383.15 \\
\pm 137.63\end{array}$ & 789.36 \\
\hline $\begin{array}{c}\Delta \boldsymbol{G}_{12} \\
(\mathrm{~kJ} / \mathrm{mol})\end{array}$ & $\begin{array}{c}49.53 \pm \\
0.09\end{array}$ & 6.67 & $\begin{array}{c}E_{a_{12}} \\
(\mathrm{~kJ} / \mathrm{mol})\end{array}$ & $\begin{array}{l}84.77 \\
\pm 0.89\end{array}$ & 2.16 & $A_{12}$ & $\begin{array}{r}6500.46 \\
\pm 70.67\end{array}$ & 309.76 \\
\hline $\begin{array}{c}\Delta \boldsymbol{G}_{13} \\
(\mathrm{~kJ} / \mathrm{mol})\end{array}$ & $\begin{array}{l}57.81 \\
\pm 4.38\end{array}$ & 1.26 & $\begin{array}{c}E_{a_{13}} \\
(\mathrm{~kJ} / \mathrm{mol})\end{array}$ & $\begin{array}{r}80.40 \\
\pm 5.96\end{array}$ & 6.09 & $\overline{A_{13}}$ & $\begin{array}{r}7018.73 \\
\pm 215.06\end{array}$ & 506.38 \\
\hline $\begin{array}{c}\Delta G_{14} \\
(\mathrm{~kJ} / \mathrm{mol})\end{array}$ & $\begin{array}{c}66.09 \pm \\
0.72\end{array}$ & 0.29 & $\begin{array}{c}E_{a_{14}} \\
(\mathrm{~kJ} / \mathrm{mol})\end{array}$ & $\begin{array}{l}21.35 \\
\pm 0.63\end{array}$ & 4.64 & $A_{14}$ & $\begin{array}{l}5426.02 \\
\pm 144.64\end{array}$ & 693.05 \\
\hline
\end{tabular}




\begin{tabular}{|c|c|c|c|c|c|c|c|c|}
\hline $\begin{array}{c}\Delta G_{15} \\
(\mathrm{~kJ} / \mathrm{mol})\end{array}$ & $\begin{array}{l}74.37 \\
\pm 4.11\end{array}$ & 1.25 & $\begin{array}{c}E_{a_{15}} \\
(\mathrm{~kJ} / \mathrm{mol})\end{array}$ & $\begin{array}{r}73.98 \\
\pm 8.31\end{array}$ & 9.17 & $A_{15}$ & $\begin{array}{r}6389.87 \\
\pm 167.5\end{array}$ & 433.62 \\
\hline $\begin{array}{c}\Delta \boldsymbol{G}_{16} \\
(\mathrm{~kJ} / \mathrm{mol})\end{array}$ & $\begin{array}{c}82.65 \pm \\
0.87\end{array}$ & 7.58 & $\begin{array}{c}E_{a_{16}} \\
(\mathrm{~kJ} / \mathrm{mol})\end{array}$ & $\begin{array}{l}88.77 \\
\pm 2.14\end{array}$ & 8.74 & $A_{16}$ & $\begin{array}{l}2402.6 \\
\pm 122.66\end{array}$ & 518.36 \\
\hline $\begin{array}{c}\Delta \boldsymbol{G}_{17} \\
(\mathrm{~kJ} / \mathrm{mol})\end{array}$ & $\begin{array}{l}90.93 \\
\pm 2.37\end{array}$ & 9.53 & $\begin{array}{c}E_{a_{17}} \\
(\mathrm{~kJ} / \mathrm{mol})\end{array}$ & $\begin{array}{l}22.28 \\
\pm 2.32\end{array}$ & 2.84 & $A_{17}$ & $\begin{array}{l}3824.54 \\
\pm 120.43\end{array}$ & 438.6 \\
\hline $\begin{array}{c}\Delta \boldsymbol{G}_{\mathbf{1 8}} \\
(\mathrm{kJ} / \mathrm{mol})\end{array}$ & $\begin{array}{l}99.21 \\
\pm 0.74\end{array}$ & 5.86 & $\begin{array}{c}E_{a_{18}} \\
(\mathrm{~kJ} / \mathrm{mol})\end{array}$ & $\begin{array}{r}143.3 \\
\pm 6.99\end{array}$ & 23.24 & $A_{18}$ & $\begin{array}{l}1824.64 \\
\pm 230.26\end{array}$ & 362.43 \\
\hline $\begin{array}{c}\Delta G_{19} \\
(\mathrm{~kJ} / \mathrm{mol})\end{array}$ & $\begin{array}{r}107.49 \\
\pm 1.33\end{array}$ & 19.08 & $\begin{array}{c}E_{a_{19}} \\
(\mathrm{~kJ} / \mathrm{mol})\end{array}$ & $\begin{array}{r}103.52 \\
\pm 3.97\end{array}$ & 19.64 & $A_{19}$ & $\begin{array}{r}5807.64 \\
\pm 271.41\end{array}$ & 768.39 \\
\hline $\begin{array}{c}\Delta \boldsymbol{G}_{20} \\
(\mathrm{~kJ} / \mathrm{mol})\end{array}$ & $\begin{array}{r}115.77 \\
\pm 8.58\end{array}$ & 14.18 & $\begin{array}{c}E_{a_{20}} \\
(\mathrm{~kJ} / \mathrm{mol})\end{array}$ & $\begin{array}{l}77.68 \\
\pm 2.27\end{array}$ & 8.32 & $A_{20}$ & $\begin{array}{l}3870.68 \\
\pm 101.46\end{array}$ & 344.54 \\
\hline $\begin{array}{c}\Delta \boldsymbol{G}_{21} \\
(\mathrm{~kJ} / \mathrm{mol})\end{array}$ & $\begin{array}{r}125.94 \\
\pm 1.82\end{array}$ & 11.24 & $\begin{array}{c}E_{a_{21}} \\
(\mathrm{~kJ} / \mathrm{mol})\end{array}$ & $\begin{array}{l}95.92 \\
\pm 1.17\end{array}$ & 5.48 & $A_{21}$ & $\begin{array}{r}1425.98 \\
\pm 66.28\end{array}$ & 150.74 \\
\hline $\begin{array}{c}\Delta \boldsymbol{G}_{22} \\
(\mathrm{~kJ} / \mathrm{mol})\end{array}$ & $\begin{array}{r}134.36 \\
\pm 0.66\end{array}$ & 10.66 & $\begin{array}{c}E_{a_{22}} \\
(\mathrm{~kJ} / \mathrm{mol})\end{array}$ & $\begin{array}{l}72.45 \\
\pm 6.27\end{array}$ & 10.36 & $A_{22}$ & $\begin{array}{l}2722.57 \\
\pm 95.6\end{array}$ & 357.34 \\
\hline $\begin{array}{c}\Delta \boldsymbol{G}_{23} \\
(\mathrm{~kJ} / \mathrm{mol})\end{array}$ & $\begin{array}{r}142.78 \\
\pm 2.82\end{array}$ & 12.34 & $\begin{array}{c}E_{a_{23}} \\
(\mathrm{~kJ} / \mathrm{mol})\end{array}$ & $\begin{array}{l}29.99 \\
\pm 2.02\end{array}$ & 5.68 & $A_{23}$ & $\begin{array}{r}3697.92 \\
\pm 83.55\end{array}$ & 480.5 \\
\hline $\begin{array}{c}\Delta \boldsymbol{G}_{24} \\
(\mathrm{~kJ} / \mathrm{mol})\end{array}$ & $\begin{array}{l}151.2 \\
\pm 0.91\end{array}$ & 15.94 & $\begin{array}{c}E_{a_{24}} \\
(\mathrm{~kJ} / \mathrm{mol})\end{array}$ & $\begin{array}{l}37.26 \\
\pm 3.28\end{array}$ & 6.06 & $A_{24}$ & $\begin{array}{l}7393.51 \\
\pm 228.1\end{array}$ & 750.74 \\
\hline $\begin{array}{c}\Delta \boldsymbol{G}_{25} \\
(\mathrm{~kJ} / \mathrm{mol})\end{array}$ & $\begin{array}{r}159.62 \\
\pm 2.69\end{array}$ & 18.55 & $\begin{array}{c}E_{a_{25}} \\
(\mathrm{~kJ} / \mathrm{mol})\end{array}$ & $\begin{array}{l}74.52 \\
\pm 2.75\end{array}$ & 3.76 & $A_{25}$ & $\begin{array}{l}2139.52 \\
\pm 139.27\end{array}$ & 466.87 \\
\hline
\end{tabular}




\begin{tabular}{|c|c|c|c|c|c|c|c|c|}
\hline $\begin{array}{c}\Delta \boldsymbol{G}_{26} \\
(\mathrm{~kJ} / \mathrm{mol})\end{array}$ & $\begin{array}{r}168.04 \\
\pm 1.13\end{array}$ & 13.94 & $\begin{array}{c}E_{a_{26}} \\
(\mathrm{~kJ} / \mathrm{mol})\end{array}$ & $\begin{array}{l}68.56 \\
\pm 3.34\end{array}$ & 5.42 & $A_{26}$ & $\begin{array}{r}4364.45 \\
\pm 154.5\end{array}$ & 745.44 \\
\hline $\begin{array}{c}\Delta \boldsymbol{G}_{27} \\
(\mathrm{~kJ} / \mathrm{mol})\end{array}$ & $\begin{array}{r}176.46 \\
\pm 3.09\end{array}$ & 16.12 & $\begin{array}{c}E_{a_{27}} \\
(\mathrm{~kJ} / \mathrm{mol})\end{array}$ & $\begin{array}{l}48.59 \\
\pm 5.91\end{array}$ & 6.69 & $A_{27}$ & $\begin{array}{l}1017.8 \\
\pm 64.62\end{array}$ & 136.06 \\
\hline $\begin{array}{c}\Delta \boldsymbol{G}_{28} \\
(\mathrm{~kJ} / \mathrm{mol})\end{array}$ & $\begin{array}{r}184.88 \\
\pm 2.65\end{array}$ & 26.19 & $\begin{array}{c}E_{a_{28}} \\
(\mathrm{~kJ} / \mathrm{mol})\end{array}$ & $\begin{array}{r}102.58 \\
\pm 1.53\end{array}$ & 10.47 & $A_{28}$ & $\begin{array}{r}1496.3 \\
\pm 78.1\end{array}$ & 153.43 \\
\hline $\begin{array}{c}\Delta \boldsymbol{G}_{29} \\
(\mathrm{~kJ} / \mathrm{mol})\end{array}$ & $\begin{array}{l}68.48 \\
\pm 0.97\end{array}$ & 1.65 & $\begin{array}{c}E_{a_{29}} \\
(\mathrm{~kJ} / \mathrm{mol})\end{array}$ & $\begin{array}{l}12.59 \\
\pm 4.6\end{array}$ & 5.39 & $A_{29}$ & $\begin{array}{l}3985.76 \\
\pm 155.75\end{array}$ & 450.59 \\
\hline $\begin{array}{c}\Delta G_{30} \\
(\mathrm{~kJ} / \mathrm{mol})\end{array}$ & $\begin{array}{l}62.5 \\
\pm 8.92\end{array}$ & 1.39 & $\begin{array}{c}E_{a_{30}} \\
(\mathrm{~kJ} / \mathrm{mol})\end{array}$ & $\begin{array}{l}69.02 \\
\pm 3.24\end{array}$ & 4.01 & $A_{30}$ & $\begin{array}{l}3700.9 \\
\pm 117.97\end{array}$ & 609.85 \\
\hline $\begin{array}{c}\Delta G_{31} \\
(\mathrm{~kJ} / \mathrm{mol})\end{array}$ & $\begin{array}{r}70.37 \\
\pm 2.94\end{array}$ & 1.79 & $\begin{array}{c}E_{a_{31}} \\
(\mathrm{~kJ} / \mathrm{mol})\end{array}$ & $\begin{array}{l}83.49 \\
\pm 4.63\end{array}$ & 6.17 & $A_{31}$ & $\begin{array}{l}2275.17 \\
\pm 153.12\end{array}$ & 303.27 \\
\hline $\begin{array}{c}\Delta \boldsymbol{G}_{32} \\
(\mathrm{~kJ} / \mathrm{mol})\end{array}$ & $\begin{array}{l}78.6 \\
\pm 5.36\end{array}$ & 0.63 & $\begin{array}{c}E_{a_{32}} \\
(\mathrm{~kJ} / \mathrm{mol})\end{array}$ & $\begin{array}{l}66.73 \\
\pm 1.19\end{array}$ & 5.34 & $A_{32}$ & $\begin{array}{l}1146.84 \\
\pm 123.19\end{array}$ & 234.19 \\
\hline $\begin{array}{c}\Delta \boldsymbol{G}_{33} \\
(\mathrm{~kJ} / \mathrm{mol})\end{array}$ & $\begin{array}{l}86.9 \\
\pm 1.32\end{array}$ & 4.89 & $\begin{array}{c}E_{a_{33}} \\
(\mathrm{~kJ} / \mathrm{mol})\end{array}$ & $\begin{array}{l}59.76 \\
\pm 2.82\end{array}$ & 3.45 & $A_{33}$ & $\begin{array}{r}3925.39 \\
\pm 198.14\end{array}$ & 663.59 \\
\hline $\begin{array}{c}\Delta \boldsymbol{G}_{34} \\
(\mathrm{~kJ} / \mathrm{mol})\end{array}$ & $\begin{array}{l}95.06 \\
\pm 3.30\end{array}$ & 4.66 & $\begin{array}{c}E_{a_{34}} \\
(\mathrm{~kJ} / \mathrm{mol})\end{array}$ & $\begin{array}{l}110.2 \\
\pm 3.35\end{array}$ & 6.21 & $A_{34}$ & $\begin{array}{l}1369.1 \\
\pm 114.35\end{array}$ & 139.89 \\
\hline $\begin{array}{c}\Delta G_{35} \\
(\mathrm{~kJ} / \mathrm{mol})\end{array}$ & $\begin{array}{l}103.2 \\
\pm 6.62\end{array}$ & 10.33 & $\begin{array}{c}E_{a_{35}} \\
(\mathrm{~kJ} / \mathrm{mol})\end{array}$ & $\begin{array}{l}112.31 \\
\pm 13.22\end{array}$ & 15.86 & $A_{35}$ & $\begin{array}{r}1078.83 \\
\pm 63.79\end{array}$ & 82.51 \\
\hline $\begin{array}{c}\Delta \boldsymbol{G}_{36} \\
(\mathrm{~kJ} / \mathrm{mol})\end{array}$ & $\begin{array}{l}111.8 \\
\pm 1.27\end{array}$ & 19.71 & $\begin{array}{c}E_{a_{36}} \\
(\mathrm{~kJ} / \mathrm{mol})\end{array}$ & $\begin{array}{l}106.45 \\
\pm 10.92\end{array}$ & 13.65 & $A_{36}$ & $\begin{array}{l}2880.1 \\
\pm 110.49\end{array}$ & 338.34 \\
\hline
\end{tabular}




\begin{tabular}{|c|c|c|c|c|c|c|c|c|}
\hline $\begin{array}{c}\Delta G_{37} \\
(\mathrm{~kJ} / \mathrm{mol})\end{array}$ & $\begin{array}{l}121.1 \\
\pm 2.94\end{array}$ & 11.32 & $\begin{array}{c}E_{a_{37}} \\
(\mathrm{~kJ} / \mathrm{mol})\end{array}$ & $\begin{array}{l}56.18 \\
\pm 6.94\end{array}$ & 9.85 & $A_{37}$ & $\begin{array}{l}487.59 \\
\pm 36.22\end{array}$ & 58.3 \\
\hline $\begin{array}{c}\Delta \boldsymbol{G}_{\mathbf{3 8}} \\
(\mathrm{kJ} / \mathrm{mol})\end{array}$ & $\begin{array}{r}129.58 \\
\pm 5.41\end{array}$ & 17.07 & $\begin{array}{c}E_{a_{38}} \\
(\mathrm{~kJ} / \mathrm{mol})\end{array}$ & $\begin{array}{l}23.71 \\
\pm 4.38\end{array}$ & 6.66 & $A_{38}$ & $\begin{array}{l}1295.7 \\
\pm 49.93\end{array}$ & 135.74 \\
\hline $\begin{array}{c}\Delta \boldsymbol{G}_{39} \\
(\mathrm{~kJ} / \mathrm{mol})\end{array}$ & $\begin{array}{r}138.07 \\
\pm 7.70\end{array}$ & 0.62 & $\begin{array}{c}E_{a_{39}} \\
(\mathrm{~kJ} / \mathrm{mol})\end{array}$ & $\begin{array}{l}47.87 \\
\pm 8.09\end{array}$ & 9.78 & $A_{39}$ & $\begin{array}{l}2768.08 \\
\pm 117.82\end{array}$ & 232.89 \\
\hline $\begin{array}{c}\Delta \boldsymbol{G}_{40} \\
(\mathrm{~kJ} / \mathrm{mol})\end{array}$ & $\begin{array}{r}146.42 \\
\pm 3.24\end{array}$ & 2.84 & $\begin{array}{c}E_{a_{40}} \\
(\mathrm{~kJ} / \mathrm{mol})\end{array}$ & $\begin{array}{l}16.04 \\
\pm 1.02\end{array}$ & 4.14 & $A_{40}$ & $\begin{array}{r}1453.91 \\
\pm 37.74\end{array}$ & 82.93 \\
\hline $\begin{array}{c}\Delta \boldsymbol{G}_{41} \\
(\mathrm{~kJ} / \mathrm{mol})\end{array}$ & $\begin{array}{l}154.84 \\
\pm 0.9\end{array}$ & 1.39 & $\begin{array}{c}E_{a_{41}} \\
(\mathrm{~kJ} / \mathrm{mol})\end{array}$ & $\begin{array}{l}116.3 \\
\pm 1.39\end{array}$ & 8.84 & $A_{41}$ & $\begin{array}{l}4331.84 \\
\pm 59.51\end{array}$ & 348.44 \\
\hline $\begin{array}{c}\Delta \boldsymbol{G}_{42} \\
(\mathrm{~kJ} / \mathrm{mol})\end{array}$ & $\begin{array}{r}163.26 \\
\pm 7.27\end{array}$ & 11.07 & $\begin{array}{c}E_{a_{42}} \\
(\mathrm{~kJ} / \mathrm{mol})\end{array}$ & $\begin{array}{r}114.34 \\
\pm 3.31\end{array}$ & 6.98 & $A_{42}$ & $\begin{array}{l}1893.3 \\
\pm 152.12\end{array}$ & 237.06 \\
\hline $\begin{array}{c}\Delta \boldsymbol{G}_{43} \\
(\mathrm{~kJ} / \mathrm{mol})\end{array}$ & $\begin{array}{r}171.68 \\
\pm 8.82\end{array}$ & 2.32 & $\begin{array}{c}E_{a_{43}} \\
(\mathrm{~kJ} / \mathrm{mol})\end{array}$ & $\begin{array}{l}87.96 \\
\pm 1.29\end{array}$ & 3.92 & $A_{43}$ & $\begin{array}{l}4294.46 \\
\pm 121.47\end{array}$ & 346.93 \\
\hline $\begin{array}{c}\Delta \boldsymbol{G}_{44} \\
(\mathrm{~kJ} / \mathrm{mol})\end{array}$ & $\begin{array}{l}180.1 \\
\pm 1.52\end{array}$ & 4.24 & $\begin{array}{c}E_{a_{44}} \\
(\mathrm{~kJ} / \mathrm{mol})\end{array}$ & $\begin{array}{r}25.49 \\
\pm 1.1\end{array}$ & 5.69 & $A_{44}$ & $\begin{array}{r}611.27 \\
\pm 97.5\end{array}$ & 127.74 \\
\hline $\begin{array}{c}\Delta \boldsymbol{G}_{45} \\
(\mathrm{~kJ} / \mathrm{mol})\end{array}$ & $\begin{array}{r}188.52 \\
\pm 3.86\end{array}$ & 2.08 & $\begin{array}{c}E_{a_{45}} \\
(\mathrm{~kJ} / \mathrm{mol})\end{array}$ & $\begin{array}{l}48.85 \\
\pm 5.61\end{array}$ & 9.07 & $A_{45}$ & $\begin{array}{l}2444.87 \\
\pm 123.61\end{array}$ & 233.49 \\
\hline $\begin{array}{c}\Delta \boldsymbol{G}_{46} \\
(\mathrm{~kJ} / \mathrm{mol})\end{array}$ & $\begin{array}{r}196.94 \\
\pm 6.07\end{array}$ & 19.29 & $\begin{array}{c}E_{a_{46}} \\
(\mathrm{~kJ} / \mathrm{mol})\end{array}$ & $\begin{array}{r}124.84 \\
\pm 3.95\end{array}$ & 18.72 & $A_{46}$ & $\begin{array}{l}5430.26 \\
\pm 147.05\end{array}$ & 699.85 \\
\hline $\begin{array}{c}\Delta \boldsymbol{G}_{47} \\
(\mathrm{~kJ} / \mathrm{mol})\end{array}$ & $\begin{array}{r}205.36 \\
\pm 1.92\end{array}$ & 22.97 & $\begin{array}{c}E_{a_{47}} \\
(\mathrm{~kJ} / \mathrm{mol})\end{array}$ & $\begin{array}{l}34.06 \\
\pm 5.69\end{array}$ & 9.31 & $A_{47}$ & $\begin{array}{r}1082.99 \\
\pm 56.49\end{array}$ & 131.54 \\
\hline
\end{tabular}




\begin{tabular}{|c|c|c|c|c|c|c|c|c|}
\hline $\begin{array}{c}\Delta \boldsymbol{G}_{48} \\
(\mathrm{~kJ} / \mathrm{mol})\end{array}$ & $\begin{array}{r}210.14 \\
\pm 1.76\end{array}$ & 25.29 & $\begin{array}{c}E_{a_{48}} \\
(\mathrm{~kJ} / \mathrm{mol})\end{array}$ & $\begin{array}{r}74.15 \\
\pm 2.92\end{array}$ & 4.54 & $A_{48}$ & $\begin{array}{l}6357.14 \\
\pm 70.9\end{array}$ & 498.54 \\
\hline $\begin{array}{c}\Delta \boldsymbol{G}_{49} \\
(\mathrm{~kJ} / \mathrm{mol})\end{array}$ & $\begin{array}{r}218.56 \\
\pm 1.83\end{array}$ & 23.85 & $\begin{array}{c}E_{a_{49}} \\
(\mathrm{~kJ} / \mathrm{mol})\end{array}$ & $\begin{array}{l}44.07 \\
\pm 1.35\end{array}$ & 5.89 & $A_{49}$ & $\begin{array}{r}3794.33 \\
\pm 193.09\end{array}$ & 340.2 \\
\hline $\begin{array}{c}\Delta \boldsymbol{G}_{\mathbf{5 0}} \\
(\mathrm{kJ} / \mathrm{mol})\end{array}$ & $\begin{array}{r}226.98 \\
\pm 1.12\end{array}$ & 6.95 & $\begin{array}{c}E_{a_{50}} \\
(\mathrm{~kJ} / \mathrm{mol})\end{array}$ & $\begin{array}{l}43.38 \\
\pm 6.33\end{array}$ & 8.27 & $A_{50}$ & $\begin{array}{r}2567.27 \\
\pm 101.48\end{array}$ & 276.97 \\
\hline $\begin{array}{c}\Delta \boldsymbol{G}_{51} \\
(\mathrm{~kJ} / \mathrm{mol})\end{array}$ & $\begin{array}{l}235.4 \\
\pm 3.1\end{array}$ & 6.22 & $\begin{array}{c}E_{a_{51}} \\
(\mathrm{~kJ} / \mathrm{mol})\end{array}$ & $\begin{array}{l}90.07 \\
\pm 3.15\end{array}$ & 6.78 & $A_{51}$ & $\begin{array}{l}4742.05 \\
\pm 177.07\end{array}$ & 408.26 \\
\hline $\begin{array}{c}\Delta \boldsymbol{G}_{52} \\
(\mathrm{~kJ} / \mathrm{mol})\end{array}$ & $\begin{array}{r}243.82 \\
\pm 6.77\end{array}$ & 3.68 & $\begin{array}{c}E_{a_{52}} \\
(\mathrm{~kJ} / \mathrm{mol})\end{array}$ & $\begin{array}{l}96.06 \\
\pm 1.13\end{array}$ & 5.56 & $A_{52}$ & $\begin{array}{l}4193.62 \\
\pm 225.73\end{array}$ & 567.33 \\
\hline $\begin{array}{c}\Delta \boldsymbol{G}_{53} \\
(\mathrm{~kJ} / \mathrm{mol})\end{array}$ & $\begin{array}{r}252.24 \\
\pm 3.71\end{array}$ & 27.73 & $\begin{array}{c}E_{a_{53}} \\
(\mathrm{~kJ} / \mathrm{mol})\end{array}$ & $\begin{array}{l}53.05 \\
\pm 2.97\end{array}$ & 4.96 & $A_{53}$ & $\begin{array}{r}2785.93 \\
\pm 51.76\end{array}$ & 309.8 \\
\hline $\begin{array}{c}\Delta \boldsymbol{G}_{54} \\
(\mathrm{~kJ} / \mathrm{mol})\end{array}$ & $\begin{array}{r}260.66 \\
\pm 1.87\end{array}$ & 2.89 & $\begin{array}{c}E_{a_{54}} \\
(\mathrm{~kJ} / \mathrm{mol})\end{array}$ & $\begin{array}{l}55.85 \\
\pm 5.77\end{array}$ & 8.89 & $A_{54}$ & $\begin{array}{l}5891.94 \\
\pm 215.35\end{array}$ & 481.97 \\
\hline $\begin{array}{c}\Delta \boldsymbol{G}_{55} \\
(\mathrm{~kJ} / \mathrm{mol})\end{array}$ & $\begin{array}{r}269.08 \\
\pm 4.57\end{array}$ & 29.71 & $\begin{array}{c}E_{a_{55}} \\
(\mathrm{~kJ} / \mathrm{mol})\end{array}$ & $\begin{array}{r}128.82 \\
\pm 3.33\end{array}$ & 18.28 & $A_{55}$ & $\begin{array}{r}3027.22 \\
\pm 149.36\end{array}$ & 513.66 \\
\hline $\begin{array}{c}\Delta \boldsymbol{G}_{56} \\
(\mathrm{~kJ} / \mathrm{mol})\end{array}$ & $\begin{array}{l}277.5 \\
\pm 1.48\end{array}$ & 21.25 & $\begin{array}{c}E_{a_{56}} \\
(\mathrm{~kJ} / \mathrm{mol})\end{array}$ & $\begin{array}{l}89.58 \\
\pm 2.25\end{array}$ & 6.38 & $A_{56}$ & $\begin{array}{r}2252.03 \\
\pm 130.05\end{array}$ & 240.41 \\
\hline$\beta_{k_{1}}$ & $\begin{array}{l}-4.193 \\
\pm 0.128\end{array}$ & 0.489 & $\beta_{k_{2}}$ & $\begin{array}{l}4.565 \\
\pm 0.025\end{array}$ & 0.213 & $\beta_{k_{3}}$ & $\begin{array}{l}-3.3389 \\
\pm 0.038\end{array}$ & 0.258 \\
\hline $\boldsymbol{\beta}_{k_{4}}$ & $\begin{array}{l}5.702 \\
\pm 0.091\end{array}$ & 0.691 & $\boldsymbol{\beta}_{k_{5}}$ & $\begin{array}{r}-4.183 \\
\pm 0.076\end{array}$ & 0.647 & $\boldsymbol{\beta}_{\boldsymbol{k}_{(1,1,2,1)}}$ & $\begin{array}{l}-1.8642 \\
\pm 0.058\end{array}$ & 0.149 \\
\hline
\end{tabular}




\begin{tabular}{|c|c|c|c|c|c|c|c|c|}
\hline $\boldsymbol{\beta}_{\boldsymbol{k}_{(3,1,4,1)}}$ & $\begin{array}{l}1.767 \\
\pm 0.155\end{array}$ & 0.499 & $\boldsymbol{\beta}_{\kappa_{1}}$ & $\begin{array}{l}2.907 \\
\pm 0.201\end{array}$ & 0.855 & $\boldsymbol{\beta}_{\kappa_{2}}$ & $\begin{array}{r}-4.293 \\
\pm 0.088\end{array}$ & 0.315 \\
\hline $\boldsymbol{\beta}_{\kappa_{3}}$ & $\begin{array}{r}-3.086 \\
\pm 0.142\end{array}$ & 0.716 & $\boldsymbol{\beta}_{\kappa_{4}}$ & $\begin{array}{l}3.719 \\
\pm 0.037\end{array}$ & 0.812 & $\boldsymbol{\beta}_{\kappa_{5}}$ & $\begin{array}{l}-4.762 \\
\pm 0.161\end{array}$ & 0.538 \\
\hline $\boldsymbol{\beta}_{\kappa_{(1,1,2,1)}}$ & $\begin{array}{r}-2.694 \\
\pm 0.041\end{array}$ & 0.431 & $\boldsymbol{\beta}_{\boldsymbol{\kappa}_{(3,1,4,1)}}$ & $\begin{array}{l}3.544 \\
\pm 0.024\end{array}$ & 0.645 & & & \\
\hline
\end{tabular}

Table 3:Statistics of the Posterior distribution for the dynamic discrepancy case 